\title{
6. SITES 403 AND 404
}

The Shipboard Scientific Party ${ }^{1}$

With a Special Contribution by

D. Mann, Department of Energy, Thames House South, London, United Kingdom

\section{SITE DATA, SITE 403}

\section{Position: $56^{\circ} 08.31^{\prime} \mathrm{N}, 23^{\circ} 17.64^{\prime} \mathrm{W}$}

Water Depth (sea level): 2301 corrected meters, echo-sounding Bottom Felt at: 2317 meters, drill pipe

Penetration: 489.0 meters

Number of Cores: 52

Total Core Recovery: 160.8 meters

Percentage Core Recovery: 32.9 per cent

\section{Oldest Sediment Cored:}

Depth sub-bottom: 489.0 meters

Nature: Tuffaceous sandstone

Age: Early Eocene-late Paleocene(?)

\section{Basement: Not reached}

Principal Results: Site 403 was drilled in 2317 meters depth on the southwest margin of the Rockall Plateau about $30 \mathrm{~km}$ from the oldest magnetic anomaly $(-24)$ recorded in the adjacent ocean crust (Figures 1 and 2).

Between the sea bed and 223 meters sub-sea, foraminifer/ nannofossil oozes and chalks of late Miocene to Recent age are present. A prominent $15-\mathrm{m} . \mathrm{y}$. hiatus between the upper Oligocene and the upper Miocene was encountered at 223 meters, with a second hiatus between the Oligocene and the middle Eocene at 232 meters. Grayish green nannofossil chalks comprise the Oligocene section whereas siliceous glauconitic nannofossil chalks with tuff layers comprise the middle Eocene. A 3.5-m.y. hiatus may separate the middle and lower Eocene at about 251 meters. Below this depth, interbedded volcaniclastics and mudstones of shallow marine deltaic aspect are present. The oldest sediments (uppermost Paleocene) include arkosic sands with a minor lignitic mudstone overlain by a tuffaceous conglomerate. Faunal and lithological evidence indicate progressive subsidence of the site from a littoral depth in latest Paleocene/earliest Eocene time to outer shelf depths by

'Lucien Montadert (Co-Chief Scientist), Institut Français du Pétrole, Rueil-Malmaison, France; David G. Roberts (Co-Chief Scientist), Institute of Oceanographic Sciences, Surrey, England: Gerard A. Auffret, Centre Océanologique de Bretagne, Brest, France; Wayne D. Bock, Rosenstiel School of Marine and Atmospheric Science, Miami, Florida; Pierre A. Dupeuble, Université de Rouen, Mont-Saint-Aignan, France; Ernest A. Hailwood, University of Southampton, Southampton, United Kingdom; William E. Harrison, University of Oklahoma, Norman, Oklahoma; Hideo Kagami, University of Tokyo, Tokyo, Japan; David N. Lumsden, Memphis State University, Memphis, Tennessee; Carla M. Müller, Geologisch-Paläontologisches Institut der Universität, Frankfurt am Main, Federal Republic of Germany (now at: Institut Français du Pétrole, Rueil-Malmaison, France); Detmar Schnitker, University of Maine, Walpole, Maine; Robert W. Thompson, Humboldt State University, Arcata, California; Thomas L. Thompson, University of Oklahoma, Norman, Oklahoma; and Peter P. Timofeev, USSR Academy of Sciences, Moscow, USSR. the middle Eocene and to depths in excess of 1000 meters by Oligocene time. The major hiatus between the Oligocene and the upper Miocene may reflect erosion or non-deposition due to more intensive bottom currents, following subsidence of the Iceland-Faeroe Rise. Rapid deposition rates of $38 \mathrm{~m} / \mathrm{m}$.y. in the upper Miocene may also be related to the influence of bottom currents.

A sonic-gamma log was run in the hole and a suite of downhole temperature measurements were taken.

\section{SITE DATA, SITE 404}

Position: $56^{\circ} 03.13^{\prime} \mathrm{N}, 23^{\circ} 14.95^{\prime} \mathrm{W}$

Water Depth (sea level): 2306 corrected meters, echo-sounding

Bottom Felt at: 2322 meters, drill pipe

Penetration: 389 meters

Number of Cores: 26

Total Core Recovery: 74.85 meters

Percentage Core Recovery: 30.7 per cent

Oldest Sediment Cored:

Depth sub-bottom: 389 meters

Nature: Sandstone

Age: Early Eocene-late Paleocene(?)

Basement: Not reached

Principal Results: Site 404 was drilled $10 \mathrm{~km}$ southeast of Site 403 on the southwest margin of the Rockall Plateau in an attempt to avoid the unconsolidated sands that had prematurely terminated drilling at Site 403. The hole was spot cored to 170 meters.

Three lithological units were recognized and can be considered equivalent to those penetrated at Site 403: Sub-unit IA $(0-28 \mathrm{~m})$ consists of an alternation of light brown calcareous mudstone and marly foraminifer ooze. Sub-unit 1B (104-199 m) of early Pliocene to late Miocene age consists of bluish white nannofossil and foraminifer ooze. Unit 2 (199-227.5 m) is composed of middle Eocene calcareous porcellanites and nannofossil porcellanites. Unlike Site 403 , the Oligocene is absent at this site. Siliceous tuffs, tuffaceous porcellanites, and glauconitic siliceous limestones of early Eocene age comprise the upper part of Unit 3 (227.5-290 m). Volcaniclastics become more common in the lower part of the unit (290-389 m) where tuffaceous mudstones prevail. Below 360 meters glauconitic sandstone and conglomerate occur in the section, and the hole ended in tuffaceous conglomerate containing a large fragment of an oyster shell.

Faunal evidence indicates progressive subsidence of the site to its present depth beginning from a littoral environment in early Eocene time.

\section{BACKGROUND AND OBJECTIVES}

The Rockall Plateau is the only micro-continent in the North Atlantic Ocean (Figures 2 and 3). It is an extensive 


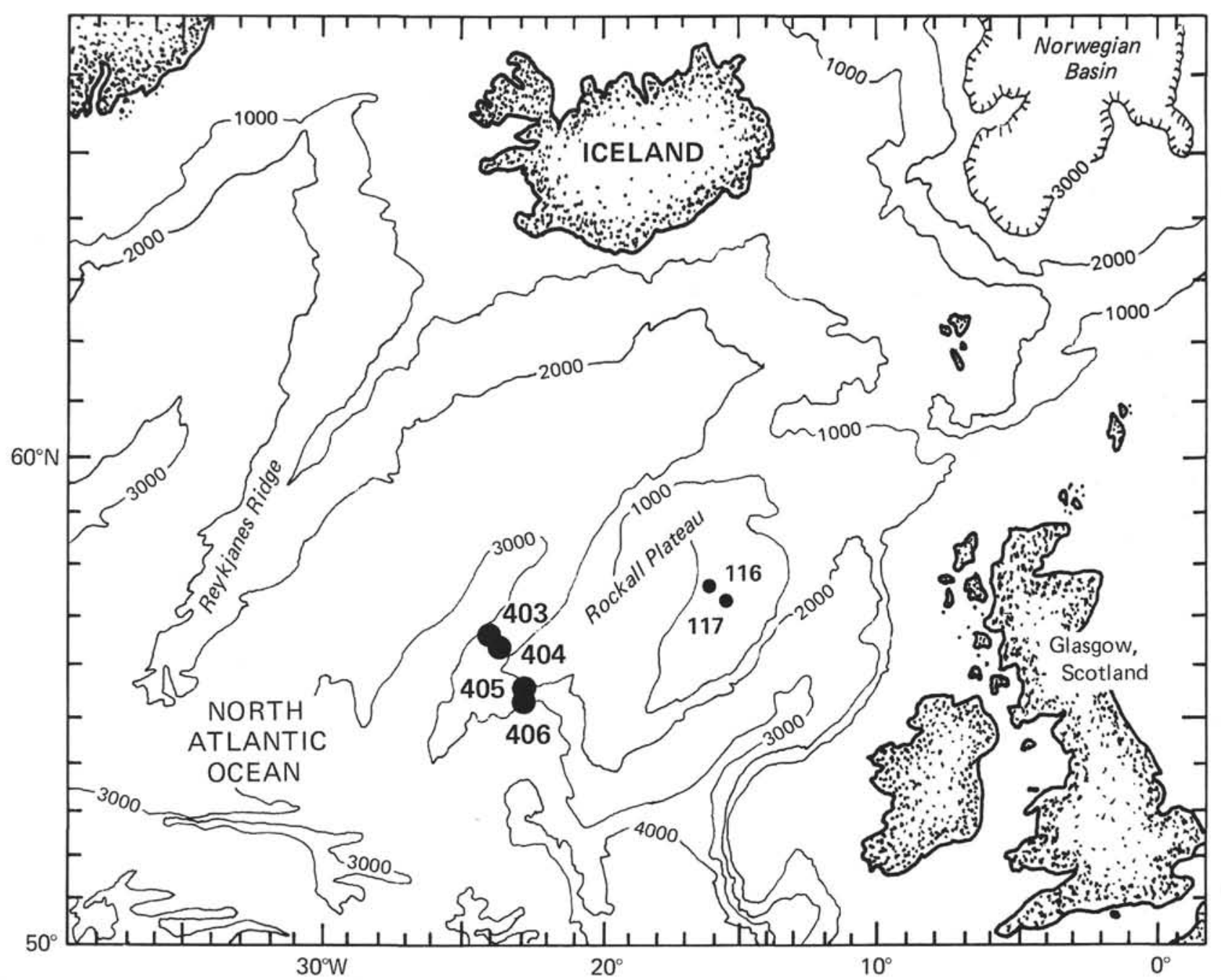

Figure 1. Northeast Atlantic bathymetry showing location of Sites 403, 404, 405, 406, 116, and 117.

shallow area the principal relief of which comprises a series of shallow banks that partly surround the deeper Hatton-Rockall Basin. The shallowest banks are Rockall Bank, which is surmounted by Rockall Island, Hatton Bank, and George Bligh Bank. The southern and westernmost elevations are the Lorien, Fangorn, and Edoras banks. To the east, west, and southwest, the plateau is bounded by steep margins; to the north the margins are ill-defined and merge with the footslopes of the Iceland-Faeroe Ridge.

Much geophysical data pertinent to the structure of the Rockall Plateau have been documented since Bullard et al. (1965) postulated that it might be a micro-continent. Deep seismic refraction lines have given continental seismic velocities and mantle depths of 33 and $22 \mathrm{~km}$ beneath the Rockall Bank and Hatton-Rockall Basin (Scrutton, 1970, 1972; Scrutton and Roberts, 1971). Based on these data, gravity modeling has confirmed earlier suggestions (Bullard et al., 1965; Roberts, 1970, 1971) that the whole plateau is a micro-continent. More recent evidence of continental crust beneath the Tertiary lavas of the Faeroe Islands may indicate a northward extension of the Rockall Plateau (Bott et al., 1971; Casten, 1973; Bott et al., 1974). Laxfordian and Grenvillian granulites dredged and drilled on the
Rockall Bank have proved the presence of continental rocks previously inferred from geochemical evidence (Roberts et al., 1972, 1973a; Miller et al., 1973; Moorbath and Welke, 1969). Studies of the planated intrusive complex around Rockall Island suggest phases of igneous activity at $52 \pm 9$ m.y. and $81 \pm 3$ m.y. (Roberts et al., 1973b). Dredgings on Hatton Bank have yielded lower Tertiary arkosic conglomerates, Watts et al. (1975). Dobson et al. (1976) have recently reported Upper Cretaceous chalks from the east margin of Rockall Bank.

West of the Rockall Plateau, the oldest ocean crust adjoining the margin is, from the identification of magnetic anomaly-24, 52 m.y. in age (Ewing and Ewing, 1958; Godby et al., 1968; Vogt et al., 1969, 1971; Scrutton and Roberts, 1971; Ruddiman, 1972; Laughton, 1971; Vogt and Avery, 1974) (Figure 3). The age of the oceanic basement abutting the southwest margin is, by the position there of anomaly-32, 73 m.y. (Vogt et al., 1971; Laughton, 1971; Vogt and Avery, 1975; Jones and Roberts, 1975). Early Cretaceous oceanic crust has been inferred to underlie the Rockall Trough (Roberts, 1971; Scrutton and Roberts, 1971; Roberts, 1974, 1975; Jones and Roberts, 1975).

Synthesis of the plate tectonic history of the North Atlantic Ocean, based on these data, has demonstrated that 


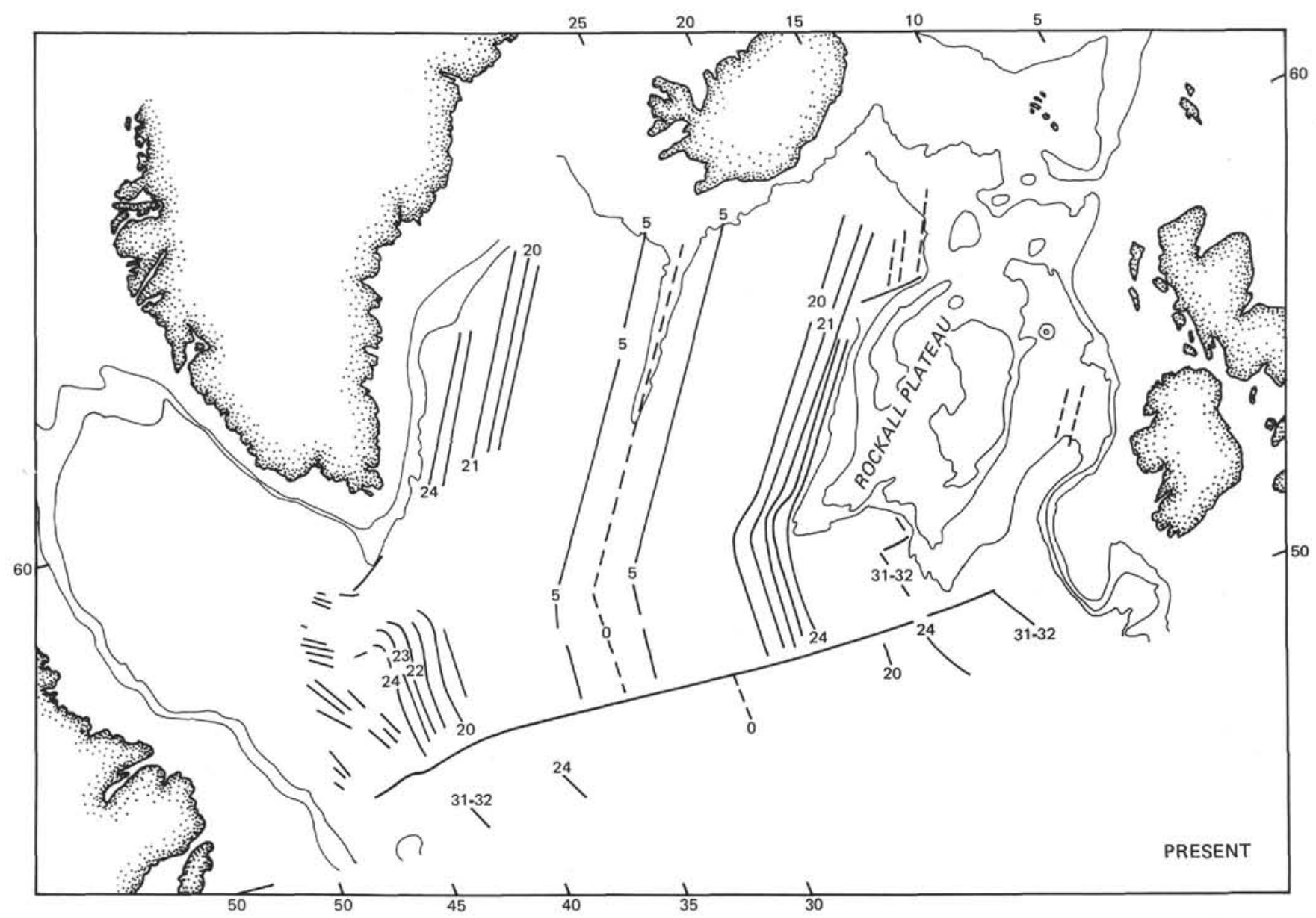

Figure 2. Magnetic anomalies in the North Atlantic Ocean (sources given in text).

three distinct phases of spreading structurally isolated the Rockall Plateau (Vogt et al., 1971; Le Pichon et al., 1972; Laughton, Berggren et al., 1971; Olivet et al., 1973; Roberts, 1975). The first phase, in Early-Middle Cretaceous time, may have contemporaneously opened the Rockall Trough and Bay of Biscay and was preceded by a rifting phase perhaps represented by the Cimmerian epeirogeny of northwest Europe (Roberts, 1971, 1975; Roberts et al., 1973; Jones and Roberts, 1975). This spreading phase, of unknown speed and duration, split off the GreenlandRockall-North American plate from Eurasia.

By 73 m.y., spreading had ceased in the Rockall Trough and the axis shifted to the line of the Labrador Sea, spreading Greenland-Rockall away from North America and creating the Gibbs fracture zone (Vogt et al., 1971; Laughton, 1971; Le Pichon et al., 1972; Olivet et al., 1974; Roberts, 1975). In the final phase, rifting and volcanism around $60 \mathrm{~m} . \mathrm{y}$. was followed by spreading at about the incipient Reykjanes Ridge axis at $52 \mathrm{~m} . \mathrm{y}$., thus completing the isolation of the Rockall Plateau micro-continent (Vogt et al., 1971; Laughton, 1971; Vogt and Avery, 1974; Roberts, 1975). Spreading continued in the Labrador Sea until about 40 m.y. On the Reykjanes Ridge, spreading decelerated from $1 \mathrm{~cm} / \mathrm{yr}$ between 52 and $38 \mathrm{~m}$.y. to $0.7 \mathrm{~cm} / \mathrm{yr}$ between 38 and $10 \mathrm{~m} . \mathrm{y}$. and accelerated to its present rate of 1.1 $\mathrm{cm} / \mathrm{yr}$ at $10 \mathrm{~m} . \mathrm{y}$. (Vogt et al., 1971; Vogt and Avery, 1974).
Sites 403 and 404 are located on the western margin of the Rockall Plateau. The margin is atypical because both shelf and shelf break are absent; the physiography thus consists of a series of poorly defined shelf-like features that are the crests of the Hatton and Edoras banks, and a continental slope.

Major changes in the trend and morphology of the slope at $59^{\circ} 30^{\prime} \mathrm{N}$ and $55^{\circ} 30^{\prime} \mathrm{N}$ (Figures 2 and 3 ) reflect both differences in the age and tectonic processes that have formed the margin. Between $55^{\circ} 30^{\prime} \mathrm{N}$ and $59^{\circ} 30^{\prime} \mathrm{N}$, the margin closely parallels the oldest $52 \mathrm{~m} . \mathrm{y}$. anomaly-24, recorded in the adjacent ocean crust (Vogt and Avery, 1974; Soper et al., 1976). South of $55^{\circ} 30^{\prime} \mathrm{N}$, the margin is rectilinear in plan. The adjoining oceanic magnetic anomalies parallel the margin south of Fangorn Bank, but are truncated northward against the steep east-west slope south of Edoras Bank. The anomalies become younger westward from anomaly-31-32 close to Lorien Bank to anomaly-24 at $25^{\circ} 30^{\prime} \mathrm{W}$ (Vogt and Avery, 1974; Jones and Roberts, 1975). The truncated anomalies suggest that the east-west margin may have been a fracture zone between 73 and $52 \mathrm{~m}$.y. In contrast, the north-south margin, parallel to the magnetic anomalies, was presumably formed by rifting prior to the onset of spreading at $73 \mathrm{~m}$.y. Clearly, the rectilinear margin pre-dates the northeast-southwest margin which formed during the final episode of rifting at $60 \mathrm{~m}$.y. and spreading at $52 \mathrm{~m} . \mathrm{y}$. The east-west segment of the 
L. Oxfordian

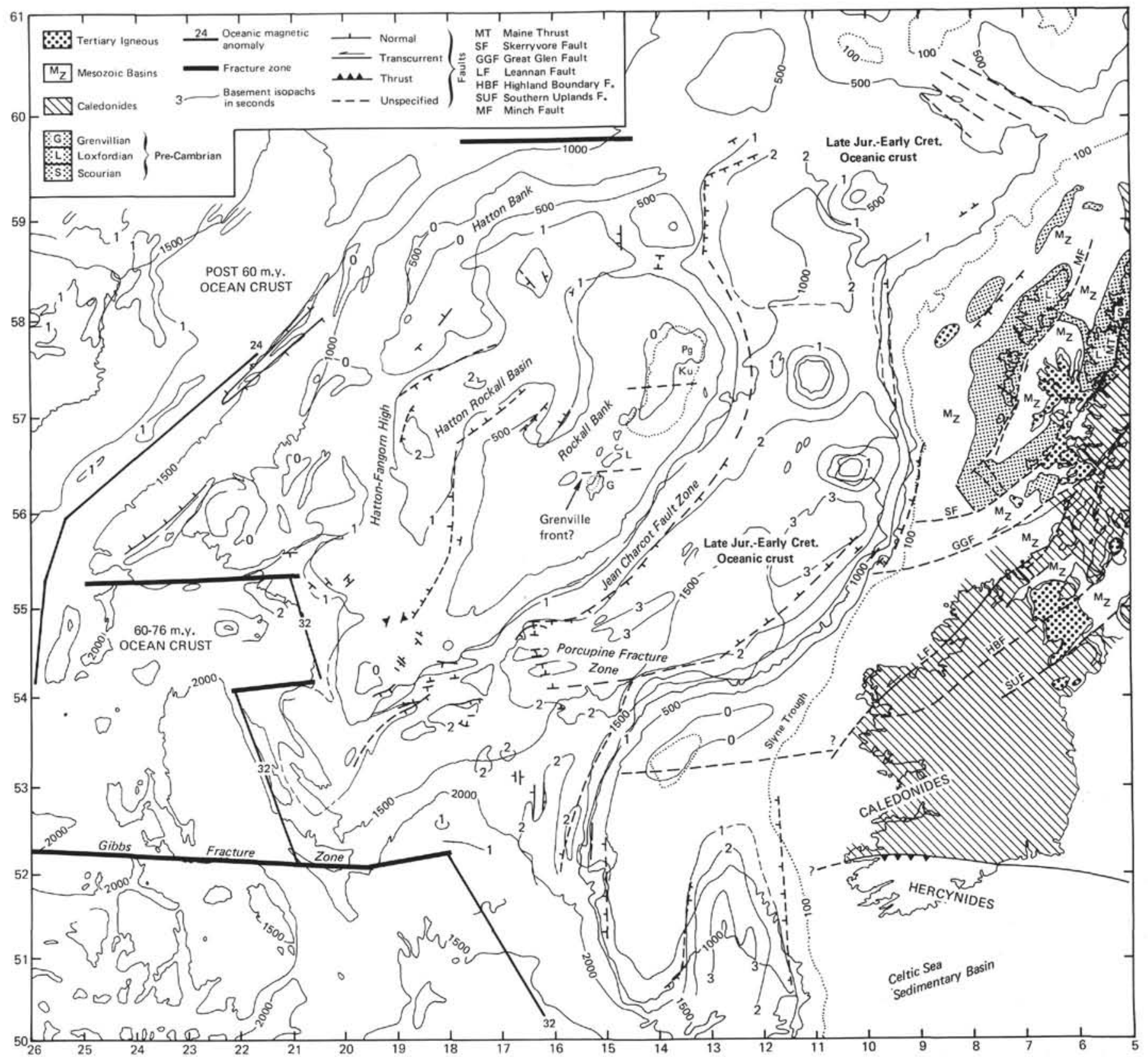

Figure 3. Main structural elements of the Rockall Plateau and Trough (from Roberts, 1975).

margin may mark a marginal fracture zone formed in the early Labrador Sea and possibly may be structurally controlled by the eastward continuation of the Grenville Front (Roberts, 1975).

The choice of Sites 403 and 404 was made from regional single-channel seismic surveys and a 24 -fold 48 trace seismic survey made by the Institute of Oceanographic Sciences supplemented by additional single-channel seismic lines occupied by Lamont-Doherty Geological Observatory. These surveys show that the southwest margin of the Rockall Plateau is structured into a series of northeasterly-trending basins that parallel anomaly-24, but also change trend southward to converge with the fracture zone south of Edoras Bank. Sites 403 and 404 (Figure 4) were located in the westernmost of these basins, about $30 \mathrm{~km}$ east of the continent/ocean boundary defined by the position of anomaly-24. The east side of the basin is a prominent fault that also controls the west scarp of Edoras Bank. Within the basin (Figure 5), a prominent reflector (reflector 1) at about $0.32 \mathrm{~s}$ marks the boundary between a well-bedded sequence below and an overlying, comparatively transparent sequence deposited under the influence of ocean bottom currents. Prior to drilling, this reflector was tentatively correlated with reflector R4 of Roberts (1975) and with the Oligocene/Eocene boundary penetrated in DSDP Site 116 (Laughton, Berggren et al., 1971). Between reflector 1 and the prominent unconformity (reflector 2 ) at $0.54 \mathrm{~s}$, the well-bedded sequence thickens westward suggesting syn-depositional subsidence. Below the unconformity, a thick faulted sequence of westerly-dipping strong reflectors of deltaic aspect is present. The faulting does not affect the section above reflector 2 . Longer multichannel seismic 


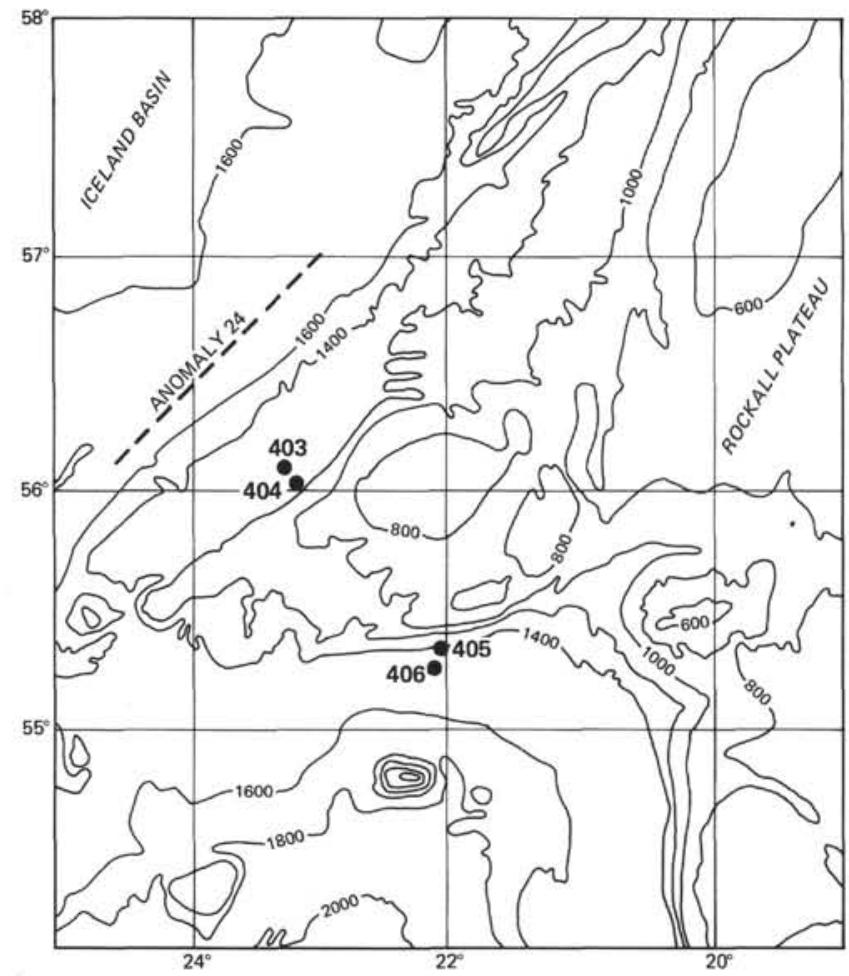

Figure 4. Bathymetry - Sites 403 and 404, Rockall Plateau.

profiles across the margin show that the sequence below reflector 2 continues westward to apparently merge with the oceanic crust (Roberts et al., this volume). Closely comparable seismic sequences have been observed on the outer Vøring Plateau and in the Lofoten Basin (Hinz, personal communication, 1975).

The premise that the majority of passive margins were formed by rifting to subsequently subside through time has proven useful in examining the broad structural and stratigraphic aspects of passive margin evolution (Curray, 1976). However, the premise has not given any direct insight into the influence of age and contrasting structural style on the evolution of the margin.

Although the west margin of Rockall Plateau is considered to have formed by rifting during the early Tertiary, the tilted block structure that characterizes the older Amorican margin of Biscay is not present. In contrast, a well-bedded and faulted sequence of unknown lithology thickens oceanward and is overlain by a prominent unconformity of regional extent.

The principal objective of Sites 403 and 404 was to examine the evolution of a young passive margin of contrasting structure and stratigraphy. Within this broad objective, it was also intended to examine the following.

\section{Regional Unconformity}

Beneath many passive margins, a regional unconformity associated with progressive onlap and the termination of a faulting episode is present. It has been considered that this unconformity marks the onset of subsidence associated with the change from rifting to sea-floor spreading. The nature of this unconformity would define the altitude of the continent at the onset of subsidence and, indirectly, date the onset of spreading between Greenland and Rockall.

\section{Rifting and Post-Rifting Environments}

If the regional unconformity was associated with the change from rifting to spreading, the nature of the beds below would help establish whether the rifting involved submarine or subaerial uplift and thus the differences and similarities both with and between the Bay of Biscay and the widely used East African rift analog. It was also important to establish the age and facies of the syn- and post-rift sediments to establish the environment and duration of rifting.

\section{Subsidence}

The seismic profiles show that subsidence continued for some time after the tilting as revealed by the regional unconformity. It was not known whether the subsidence was continuous or discontinuous. Comparison of the subsidence history with that of Biscay and the results of DSDP Sites 116 and 117 in the Hatton-Rockall Basin would contribute to an assessment of the relationship between subsidence and sea-floor spreading rate changes.

\section{Comparative Facies Studies}

The objective was to compare the facies of the syn- and post-rift sediments and to assess the effects of increasing depth by subsidence and changing oceanographic conditions.

\section{Paleoceanography}

Sedimentation throughout the Neogene has been closely influenced by changes in bottom water circulation resulting, for example, from subsidence of the Iceland-Faeroe Rise. The effects of these changes on the CCD and carbonate and silica production has a specific relevance to margin stratigraphy and broadly to North Atlantic stratigraphy.

\section{Diagenesis}

The objectives included the diagenesis of clay, carbonate, and siliceous sediments and the maturation of organic matter in relation to the rapidly changing thermal conditions on a young margin.

\section{Paleomagnetism}

Correlation of the Tertiary magnetic reversal history with biostratigraphic data in continuously cored sections was a prime objective.

\section{Logging}

Correlation of electric logs with seismic reflection data, lithologic logs, and measurements of the physical properties of the sediments was an integral part of the study.

\section{SITE APPROACH AND DRILLING OPERATIONS}

\section{Site $\mathbf{4 0 3}$}

Unlike previous sites in the Bay of Biscay, where safety and scientific objectives required precise positioning, some deviation in positioning was here permissible in view of the minimal changes in geology, both downdip and along 


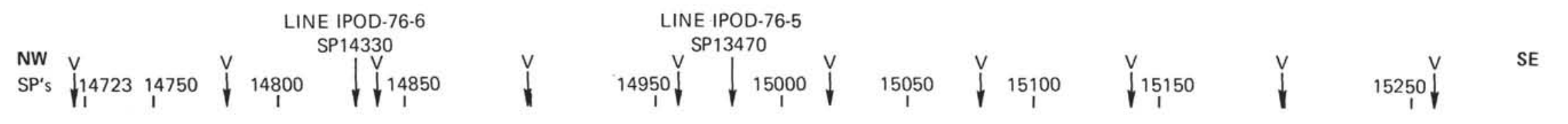

Site 403

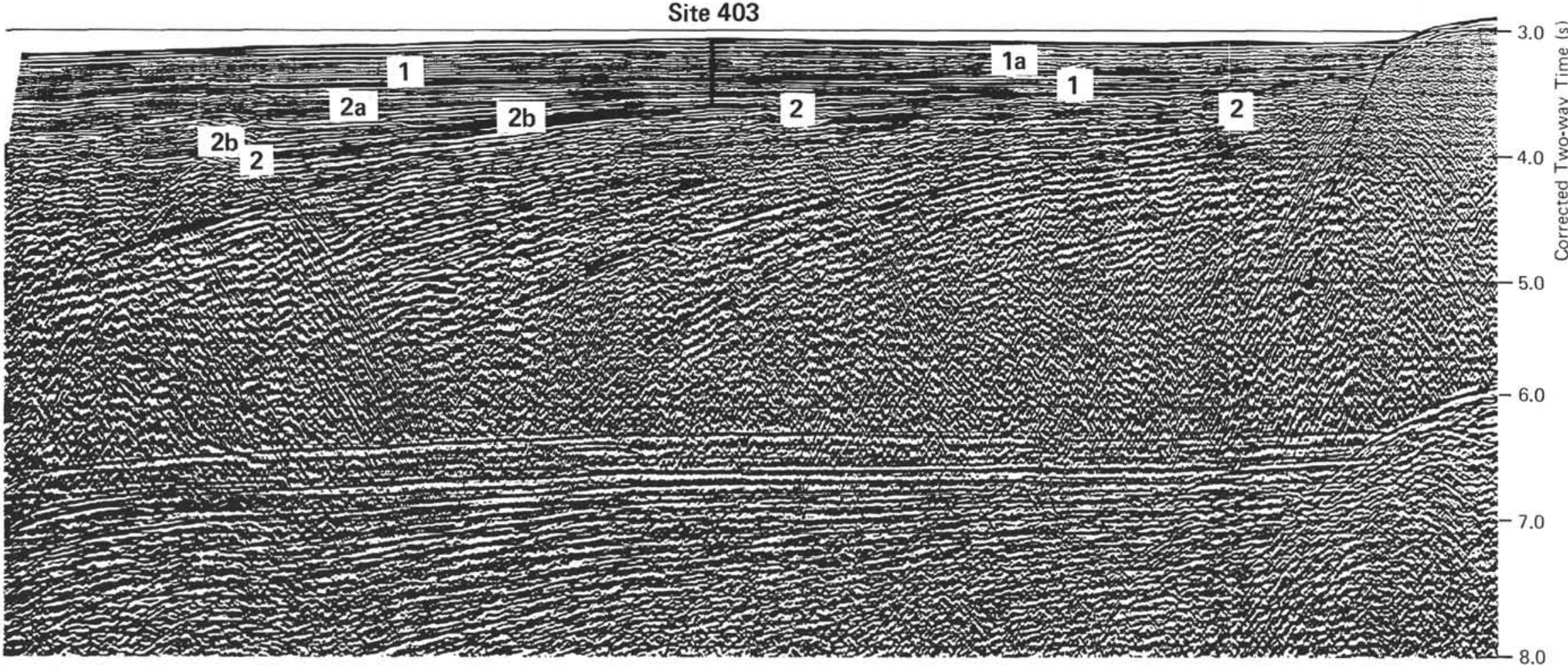

Figure 5. Multichannel seismic profile IPOD 76-7 through Site 403. 
strike. The site approach was therefore planned to directly occupy the control seismic line IPOD-76-7 across the site using as position checks channels and the prominent scarp flanking the basin.

The site (Figure 6) was approached along $306^{\circ}$ early on 20 June and, at 0044 hours, course was adjusted to $314^{\circ}$ to run directly along the control seismic profile. At 0126 hours on 20 June, speed was reduced to $120 \mathrm{rpm}$ to observe reflectors more easily. As the site was crossed at 0223 , a $13.5-\mathrm{kHz}$ beacon was deployed and, after retrieving the geophysical gear, Glomar Challenger began positioning and maneuvering to the beacon.

At 1030 hours on 20 June, Site 403 was spudded in 2317 meters below the rig floor and a 4.83 -meter core of Pleistocene foraminifer-nannofossil ooze was cut at the mudline. The hole was thereafter cored continuously to total depth (TD) (Table 1). Heat-flow measurements were made at $33.0,61.5,99.5,147.0,154.5$, and 242.0 meters sub-sea, of which only the first was unsuccessful. At 1830 hours, during the measurement at 61.5 meters, an excursion of 500 feet occurred, resulting in the pipe being pulled back. By 1935 hours, position had been re-established and drilling with continuous coring recommenced. In Cores 47 through 52 , core recovery declined to nearly zero, even though 15 barrels at 8.9 wt. 6.7 vis mud were successively spotted after Cores 46 and 47 . This low recovery was attributable to unconsolidated sandstones. Because drilling torque increased, drilling was terminated at 489.0 meters sub-sea to avoid loss of the drill string.

Preparations to log the hole at Site 403 began at 0600 hours on 23 June, when pipe was pulled to wipe the hole clean. Twenty barrels of 8.9 vis mud were spotted before running in the rotary shifting tool. The bit was successfully released at 1115 hours on 23 June at 2802 meters below the rig floor. Between 1200 and 1330 hours, the hole was filled with 175 barrels of 8.9 wt. 6.7 vis mud before pulling back the pipe to hang at 2432 meters below the rig floor. The first logging run was made using a gamma/sonic tool (BHC-GR-CAL). Although a bridge at 2746 meters halted the tool briefly, the hole was logged finally from 2815

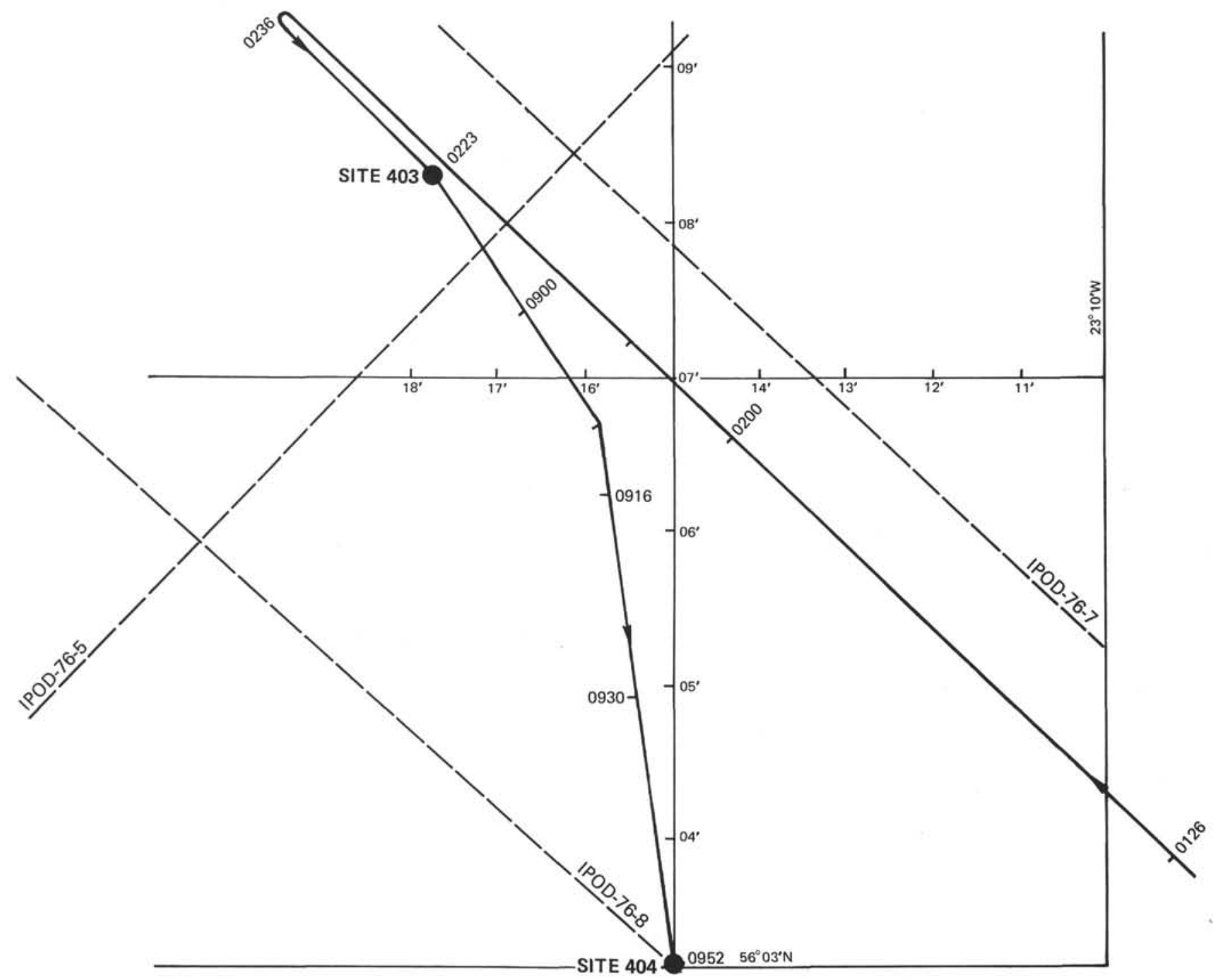

Figure 6. Approach to Glomar Challenger to Sites 403 and 404. 
TABLE 1

Coring Summary, Site 403

\begin{tabular}{|c|c|c|c|c|c|c|c|c|c|}
\hline \multirow{2}{*}{$\frac{\text { Core }}{1}$} & \multirow{2}{*}{$\begin{array}{c}\begin{array}{c}\text { Date } \\
\text { (June 1976) }\end{array} \\
20\end{array}$} & \multirow{2}{*}{$\begin{array}{l}\text { Time } \\
1058\end{array}$} & \multicolumn{2}{|c|}{$\begin{array}{l}\text { Depth From Drill } \\
\text { Floor }(\mathrm{m})\end{array}$} & \multicolumn{2}{|c|}{$\begin{array}{c}\text { Depth Below Sea } \\
\text { Floor }(\mathrm{m})\end{array}$} & \multirow{2}{*}{$\begin{array}{c}\begin{array}{c}\text { Length } \\
\text { Cored } \\
(\mathrm{m})\end{array} \\
4.5\end{array}$} & \multirow{2}{*}{$\begin{array}{c}\begin{array}{c}\text { Length } \\
\text { Recovered } \\
(\mathrm{m})\end{array} \\
4.83\end{array}$} & \multirow{2}{*}{$\begin{array}{c}\begin{array}{c}\text { Recovery } \\
(\%)\end{array} \\
100\end{array}$} \\
\hline & & & 2317.0 & 2321.5 & 0 & 4.5 & & & \\
\hline 2 & 20 & 1145 & 2321.5 & 2331.0 & 4.5 & 14.0 & 9.5 & 9.1 & 95 \\
\hline 3 & 20 & 1238 & 2331.0 & 2340.5 & 14.0 & 23.5 & 9.5 & 3.26 & 34 \\
\hline 4 & 20 & 1330 & 2340.5 & 2350.0 & 23.5 & 33.0 & 9.5 & 1.10 & 11.5 \\
\hline 5 & 20 & 1425 & 2350.0 & 2359.5 & 33.0 & 42.5 & 9.5 & 4.36 & 40 \\
\hline 6 & 20 & 1640 & 2359.5 & 2369.0 & 42.5 & 52.0 & 9.5 & 0.10 & 1 \\
\hline 7 & 20 & 1731 & 2369.0 & 2378.5 & 52.0 & 61.5 & 9.5 & 2.71 & 20 \\
\hline 8 & 20 & 2019 & 2378.5 & 2388.0 & 61.5 & 71.0 & 9.5 & 9.6 & 100 \\
\hline 9 & 20 & 2121 & 2388.0 & 2397.5 & 71.0 & 80.5 & 9.5 & 7.76 & 81 \\
\hline 10 & 20 & 2215 & 2397.5 & 2407.0 & 80.5 & 90.0 & 9.5 & 0.1 & 1 \\
\hline 11 & 20 & 2350 & 2407.0 & 2416.5 & 90.0 & 99.5 & 9.5 & 3.92 & 41 \\
\hline 12 & 21 & 0248 & 2416.5 & 2426.0 & 99.5 & 109.0 & 9.5 & 9.55 & 100 \\
\hline 13 & 21 & 0345 & 2426.0 & 2435.5 & 109.0 & 118.5 & 9.5 & 3.49 & 36 \\
\hline 14 & 21 & 0449 & 2435.5 & 2445.0 & 118.5 & 128.0 & 9.5 & 2.28 & 24 \\
\hline 15 & 21 & 0608 & 2445.0 & 2454.5 & 128.0 & 137.5 & 9.5 & 0.10 & 1 \\
\hline 16 & 21 & 0715 & 2454.5 & 2464.0 & 137.5 & 147.0 & 9.5 & 6.10 & 64 \\
\hline 17 & 21 & 0935 & 2464.0 & 2473.5 & 147.0 & 156.5 & 9.5 & 2.15 & 23 \\
\hline 18 & 21 & 1045 & 2473.5 & 2483.0 & 156.5 & 166.0 & 9.5 & 2.83 & 29 \\
\hline 19 & 21 & 1145 & 2483.0 & 2492.5 & 166.0 & 175.5 & 9.5 & 3.02 & 31.7 \\
\hline 20 & 21 & 1305 & 2492.5 & 2502.0 & 175.5 & 185.0 & 9.5 & 1.03 & 10.8 \\
\hline 21 & 21 & 1419 & 2502.0 & 2511.5 & 185.0 & 194.5 & 9.5 & 4.36 & 45.8 \\
\hline 22 & 21 & 1620 & 2511.5 & 2521.0 & 194.5 & 204.0 & 9.5 & 8.49 & 89 \\
\hline 23 & 21 & 1734 & 2521.0 & 2530.5 & 204.0 & 213.5 & 9.5 & 1.04 & 11 \\
\hline 24 & 21 & 1847 & 2530.5 & 2540.0 & 213.5 & 223.0 & 9.5 & 0.63 & 7 \\
\hline 25 & 21 & 2007 & 2540.0 & 2549.5 & 223.0 & 232.5 & 9.5 & 0.60 & 6 \\
\hline 26 & 21 & 2109 & 2549.5 & 2559.0 & 232.5 & 242.0 & 9.5 & 5.09 & 54 \\
\hline 27 & 21 & 2330 & 2559.0 & 2568.5 & 242.0 & 251.5 & 9.5 & 0.33 & 3.5 \\
\hline 28 & 22 & 0057 & 2568.5 & 2578.0 & 251.5 & 261.0 & 9.5 & 1.0 & 10.5 \\
\hline 29 & 22 & 0200 & 2578.0 & 2587.5 & 261.0 & 270.5 & 9.5 & 8.09 & 85 \\
\hline 30 & 22 & 0307 & 2587.5 & 2597.0 & 270.5 & 280.0 & 9.5 & 0.57 & 6 \\
\hline 31 & 22 & 0400 & 2597.0 & 2606.5 & 280.0 & 289.5 & 9.5 & 0.12 & 1.2 \\
\hline 32 & 22 & 0509 & 2606.5 & 2616.0 & 289.5 & 299.0 & 9.5 & 0.30 & 3.2 \\
\hline 33 & 22 & 0615 & 2616.0 & 2625.5 & 299.0 & 308.5 & 9.5 & 0.60 & 6 \\
\hline 34 & 22 & 0715 & 2625.5 & 2635.0 & 308.5 & 318.0 & 9.5 & 7.98 & 84 \\
\hline 35 & 22 & 0820 & 2635.0 & 2644.5 & 318.0 & 327.5 & 9.5 & 6.20 & 65 \\
\hline 36 & 22 & 0940 & 2644.5 & 2654.0 & 327.5 & 337.0 & 9.5 & 2.28 & 24 \\
\hline 37 & 22 & 1040 & 2654.0 & 2663.5 & 337.0 & 346.5 & 9.5 & 8.03 & 85 \\
\hline 38 & 22 & 1140 & 2663.5 & 2673.0 & 346.5 & 356.0 & 9.5 & 5.45 & 57 \\
\hline 39 & 22 & 1350 & 2673.0 & 2682.5 & 356.0 & 365.5 & 9.5 & 4.08 & 43 \\
\hline 40 & 22 & 1455 & 2682.5 & 2692.0 & 365.5 & 375.0 & 9.5 & 4.19 & 44 \\
\hline 41 & 22 & 1650 & 2692.0 & 2701.5 & 375.0 & 384.5 & 9.5 & 6.73 & 71 \\
\hline 42 & 22 & 1814 & 2701.5 & 2711.0 & 384.5 & 394.0 & 9.5 & 4.0 & 42 \\
\hline 43 & 22 & 1915 & 2711.0 & 2720.5 & 394.0 & 403.5 & 9.5 & 1.40 & 15 \\
\hline 44 & 22 & 2013 & 2720.5 & 2730.0 & 403.5 & 413.0 & 9.5 & 0.19 & 2 \\
\hline 45 & 22 & 2118 & 2730.0 & 2739.5 & 413.0 & 422.5 & 9.5 & 0.17 & 2 \\
\hline 46 & 22 & 2235 & 2739.5 & 2749.0 & 422.5 & 432.0 & 9.5 & 1.12 & 11 \\
\hline 47 & 22 & 2332 & 2749.0 & 2758.5 & 432.0 & 441.5 & 9.5 & 0 & 0 \\
\hline 48 & 23 & 0037 & 2758.5 & 2768.0 & 441.5 & 451.0 & 9.5 & 0.20 & 1.6 \\
\hline 49 & 23 & 0200 & 2768.0 & 2777.5 & 451.0 & 460.5 & 9.5 & 0.03 & 0.3 \\
\hline 50 & 23 & 0305 & 2777.5 & 2787.0 & 460.5 & 470.0 & 9.5 & 0.02 & 0.2 \\
\hline 51 & 23 & 0410 & 2787.0 & 2796.5 & 470.0 & 479.5 & 9.5 & 0.12 & 1.2 \\
\hline 52 & 23 & 0550 & 2796.5 & 2806.0 & 479.5 & 489.0 & 9.5 & 0.03 & 0.3 \\
\hline Totals & & & & & & & 480.0 & 160.83 & 32.9 \\
\hline
\end{tabular}

meters sub-sea to the end of the pipe. During logging operations, wind and sea conditions deteriorated until rolls of 12 degrees and wind gusts of 40 knots culminated in an excursion of 100 feet at 1755 hours on 23 June. Although the sonic-gamma run had been completed by 1800 hours and the ISF tool run in hole, logging operations were therefore suspended at 1800 hours. Following a further excursion of 800 feet, the pipe was pulled out of the hole by 1900 hours, thus terminating operations at Site 403 . The pipe was slowly tripped from 2040 hours on 23 June and retrieved completely by 1100 hours on 24 June. Pending an improvement in the weather, Glomar Challenger remained on station at Site 403 before moving to Site 404 .

\section{Site 404}

Site 403 prematurely was abandoned short of its objective, reflector 2 , due to the difficulties experienced in drilling through unconsolidated sands. Correlation of the seismic reflection profile across Site 403 with the logging results and the lithologies cored allowed tentative identification of the top of the unconsolidated sands, which appeared to wedge-out eastward against reflector 2. A 
comparison of the multichannel seismic profiles across the basin showed an alternative site where reflector 2 could be reached and penetrated without drilling through the unconsolidated sands encountered at Site 403 . Site 404 was therefore located at SP15460 on line IPOD-76-8 where only a thin intra-reflector 1-2 sequence rested on reflector 2 , the presumed upper Paleocene unconformity.

Following an improvement in weather conditions Glomar Challenger departed Site 403 for Site 404 at 0549 hours on 25 June. No geophysical gear was streamed as Site 404 lay only a few miles to the south, in an easily identifiable position on the edge of a channel. The site approach was timed to coincide with good satellite fixes (Figure 6).

Site 404 was approached along a heading of 150 degrees at 5 knots. Satellite fixes showed a northward set and, at 0911 hours on 25 June, course was adjusted to 174 degrees to make the position of Site 404 . A $16-\mathrm{kHz}$ beacon was dropped as the vessel crossed the edge of the channel (observed on the PDR) close to the site and the vessel began maneuvering to the beacon. Glomar Challenger remained stationed on the beacon until 1400 hours on 26 June when wind and sea conditions had moderated enough (wind 25-30 knots, sea $10-12 \mathrm{ft}$ ) to begin picking up the bottom hole assembly. At 1515 hours on 26 June, pipe was run in hole and Site 404 was spudded at 2322 meters below the rig floor at 2120 hours on 26 June.

As the Quaternary and Neogene section had been continuously cored at Site 403, it was decided to spot core until 170 meters sub-sea. A 9.11-meter core of Pleistocene nannofossil/foraminifer ooze was cut at the mudline.
However, as a hard layer was encountered in washing from 2331.0 to 2343.5 meters, a further core of marly nannofossil/foraminifer ooze was cut between 21.5 and 28.0 meters sub-sea to check the lithology. Between this depth and 170.5 meters, only one core was cut at 104.0 meters sub-sea. Continuous coring proceeded without incident to 246.5 meters sub-sea (Table 2) when 15 barrels of 8.9 wt. 6.7 vis mud were spotted to clean the hole. Torquing, which did not continue, was experienced while cutting Core 13 from 256.0 to 265.5 meters sub-sea. Cores 14 to 25 yielded a variable recovery of between 0.22 and 9.2 meters reflecting the alternating sequence of sandstones and mudstones then being drilled. While Core 26 was being cut between 0430 and 0515 hours on 28 June, weather conditions deteriorated suddenly and rapidly. At 0500 hours, 40-knot gusts of wind occurred with an increasing swell and sea. By 0530 hours, it was difficult maintaining position to 200 feet in the semi-automatic mode. The wind speed had meanwhile increased to 45 knots and the seas to between 10 and 12 feet. The pipe was pulled at 0530 hours and the mudline cleared at 0630 hours, ending drilling operations. Although all drill pipe was laid down by 1000 hours, the bottom hole assembly was hung off as the ship could no longer maintain heading. The heavy seas and strong winds persisted throughout much of 28 June, but had moderated sufficiently by 1930 hours on 28 June to lay down the bottom hole assembly with care. All gear was secured by 2100 hours and the ship remained hove to pending sufficient improvement in the weather to move to Site 405 .

TABLE 2

Coring Summary, Site 404

\begin{tabular}{|c|c|c|c|c|c|c|c|c|c|}
\hline \multirow{2}{*}{$\frac{\text { Core }}{1}$} & \multirow{2}{*}{$\begin{array}{c}\begin{array}{c}\text { Date } \\
\text { (June 1976) }\end{array} \\
26\end{array}$} & \multirow{2}{*}{$\begin{array}{l}\text { Time } \\
2215\end{array}$} & \multicolumn{2}{|c|}{$\begin{array}{l}\text { Depth From Drill } \\
\text { Floor (m) }\end{array}$} & \multicolumn{2}{|c|}{$\begin{array}{l}\text { Depth Below Sea } \\
\text { Floor (m) }\end{array}$} & \multirow{2}{*}{$\begin{array}{c}\begin{array}{c}\text { Length } \\
\text { Cored } \\
\text { (m) }\end{array} \\
9.0\end{array}$} & \multirow{2}{*}{$\begin{array}{c}\begin{array}{c}\text { Length } \\
\text { Recovered } \\
(\mathrm{m})\end{array} \\
9.11\end{array}$} & \multirow{2}{*}{$\begin{array}{c}\begin{array}{c}\text { Recovery } \\
(\%)\end{array} \\
100\end{array}$} \\
\hline & & & 2322.0 & 2331.0 & 0 & 9.0 & & & \\
\hline 2 & 27 & 0026 & 2343.5 & 2350.0 & 21.5 & 28.0 & 6.5 & 9.24 & $100+$ \\
\hline 3 & 27 & 0320 & 2426.0 & 2435.5 & 104.0 & 113.5 & 9.5 & 1.0 & 10.5 \\
\hline 4 & 27 & 0522 & 2492.5 & 2502.0 & 170.5 & 180.0 & 9.5 & 2.76 & 29 \\
\hline 5 & 27 & 0620 & 2502.0 & 2511.5 & 180.0 & 189.5 & 9.5 & 2.96 & 31 \\
\hline 6 & 27 & 0718 & 2511.5 & 2521.0 & 189.5 & 199.0 & 9.5 & 1.70 & 18 \\
\hline 7 & 27 & 0805 & 2521.0 & 2530.5 & 199.0 & 208.5 & 9.5 & 3.75 & 39 \\
\hline 8 & 27 & 0855 & 2530.0 & 2540.0 & 208.5 & 218.0 & 9.5 & 1.95 & 21 \\
\hline 9 & 27 & 0907 & 2540.0 & 2549.5 & 218.0 & 227.5 & 9.5 & 0.18 & 0.2 \\
\hline 10 & 27 & 1034 & 2549.5 & 2559.0 & 227.5 & 237.0 & 9.5 & 0.69 & 0.7 \\
\hline 11 & 27 & 1135 & 2559.0 & 2568.5 & 237.0 & 246.5 & 9.5 & 0.75 & 0.7 \\
\hline 12 & 27 & 1255 & 2568.5 & 2578.0 & 246.5 & 256.0 & 9.5 & 0.65 & 0.68 \\
\hline 13 & 27 & 1430 & 2578.0 & 2587.5 & 256.0 & 265.5 & 9.5 & 0.38 & 0.40 \\
\hline 14 & 27 & 1602 & 2587.5 & 2597.0 & 265.5 & 275.0 & 9.5 & 0.48 & 0.50 \\
\hline 15 & 27 & 1717 & 2597.0 & 2606.5 & 275.0 & 284.5 & 9.5 & 0.37 & 0.38 \\
\hline 16 & 27 & 1835 & 2606.5 & 2616.0 & 284.5 & 294.0 & 9.5 & 3.18 & 33.5 \\
\hline 17 & 27 & 1957 & 2616.0 & 2625.5 & 294.0 & 303.5 & 9.5 & 6.66 & 70 \\
\hline 18 & 27 & 2107 & 2625.5 & 2635.0 & 303.5 & 313.0 & 9.5 & 2.38 & 25 \\
\hline 19 & 27 & 2201 & 2635.0 & 2644.5 & 313.0 & 322.5 & 9.5 & 0.35 & 3.6 \\
\hline 20 & 27 & 2306 & 2644.5 & 2654.0 & 322.5 & 332.0 & 9.5 & 0.85 & 8.9 \\
\hline 21 & 28 & 0010 & 2654.0 & 2663.5 & 332.0 & 341.5 & 9.5 & 5.55 & 48.4 \\
\hline 22 & 28 & 0112 & 2663.5 & 2673.0 & 341.5 & 351.0 & 9.5 & 9.2 & 97 \\
\hline 23 & 28 & 0220 & 2673.0 & 2682.5 & 351.0 & 360.5 & 9.5 & 8.99 & 95 \\
\hline 24 & 28 & 0320 & 2682.5 & 2692.0 & 360.5 & 370.0 & 9.5 & 0.22 & 2.3 \\
\hline 25 & 28 & 0432 & 2692.0 & 2701.5 & 370.0 & 379.5 & 9.5 & 1.27 & 13 \\
\hline 26 & 28 & 2055 & 2701.5 & 2711.0 & 379.5 & 389.0 & 9.5 & 0.23 & 2 \\
\hline Totals & & & & & & & 243.5 & 74.85 & 30.7 \\
\hline
\end{tabular}




\section{LITHOLOGY, SITE 403}

A total section of 499 meters was drilled at Site 403 in sediments ranging in age from Quaternary to probably the late Paleocene. Near the bottom of the hole the oldest sediments penetrated comprise a sequence of nonfossiliferous arkosic sands and sandstones with minor interbeds of lignitic mudstone and cross-laminated siltstone. These are interpreted as marginal marine, perhaps deltaic, deposits. Extrapolation of sedimentation rates and palynology indicates they are late Paleocene. The sandstones are overlain sequentially by a fossiliferous tuffaceous conglomerate, probably representing a transgression, and a thick, rapidly deposited sequence of interbedded tuffs and dark gray to black mudstones of shallow marine, deltaic aspect. These range in age from Paleocene to early Eocene. A profound change in sedimentation conditions apparently began in early to middle Eocene time; the remainder of the Paleogene record is fragmentary. Thus, the entire time span from $50 \mathrm{~m} . \mathrm{y}$. to $10 \mathrm{~m} . \mathrm{y}$. is represented by about 30 meters of lower-middle Eocene glauconitic chalk and a maximum 10 meters of middle-upper Oligocene glauconitic chalk. Two prolonged hiatuses, middle Eocene to middle Oligocene, and upper Oligocene to upper Miocene, are indicated. By late Miocene time, conditions approached those which are extant and a thick sequence of white nannofossil to foraminifer nannofossil ooze accumulated at a rapid rate ( $38 \mathrm{~m} / \mathrm{m} . \mathrm{y}$.). With the onset of climatic changes in the late Pliocene and Quaternary, sedimentation rates slowed somewhat so that the uppermost section is characterized by alternating calcareous ooze, marly ooze, and calcareous mud, all of which are sprinkled with ice-rafted pebbles and terrigenous sands.

Three main lithologic units and five sub-units are distinguished within the section. These are summarized in Table 3 and Figure 7, and are described below from the top down.

TABLE 3

Lithologic Units, Site 403

\begin{tabular}{|c|c|c|c|c|c|}
\hline Unit & Sub-Unit & Cores & $\begin{array}{l}\text { Sub-Bottom } \\
\text { Depth (m) }\end{array}$ & Lithology & Age \\
\hline \multirow[t]{3}{*}{1} & $1 \mathrm{~A}$ & $1-6$ & $0-45$ & $\begin{array}{l}\text { Nannofossil ooze, } \\
\text { marly foraminifer/ } \\
\text { nannofossil ooze, } \\
\text { calcareous mud }\end{array}$ & $\begin{array}{l}\text { Quaternary- } \\
\text { Pliocene }\end{array}$ \\
\hline & 1B & $7-24$ & $45-223$ & $\begin{array}{l}\text { Nannofossil ooze, } \\
\text { foraminifer/nanno- } \\
\text { fossil ooze, } \\
\text { foraminifer/nannofossil } \\
\text { chalk }\end{array}$ & $\begin{array}{l}\text { Pliocene- } \\
\text { late Miocene }\end{array}$ \\
\hline & \multicolumn{5}{|c|}{ HIATUS } \\
\hline $2^{\mathrm{a}}$ & $\cdots$ & $25-28$ & $223-260$ & $\begin{array}{l}\text { Foraminifer/nannofossil } \\
\text { chalk } \\
\text { siliceous nannofossil } \\
\text { chalk }\end{array}$ & $\begin{array}{l}\text { Oligocene- } \\
\text { carly Eocene }\end{array}$ \\
\hline \multirow[t]{3}{*}{3} & $3 \mathrm{~A}$ & $29-40$ & $260-368$ & $\begin{array}{l}\text { Mudstone, } \\
\text { tuffaceous mudstone, } \\
\text { tuff }\end{array}$ & $\begin{array}{l}\text { Early Eocene- } \\
\text { late Paleocene (?) }\end{array}$ \\
\hline & 3B & $40-45$ & $368-418$ & $\begin{array}{l}\text { Muddy tuff, } \\
\text { lapilli tuff, } \\
\text { lapilli conglomerate }\end{array}$ & Late Paleocene (?) \\
\hline & $3 C$ & $45-52$ & $418-489$ & Arkosic sandstone & Late Paleocene (?) \\
\hline
\end{tabular}

${ }^{a} \mathrm{~A}$ hiatus between mid-Oligocene and mid-Eocene occurs within Unit 2.

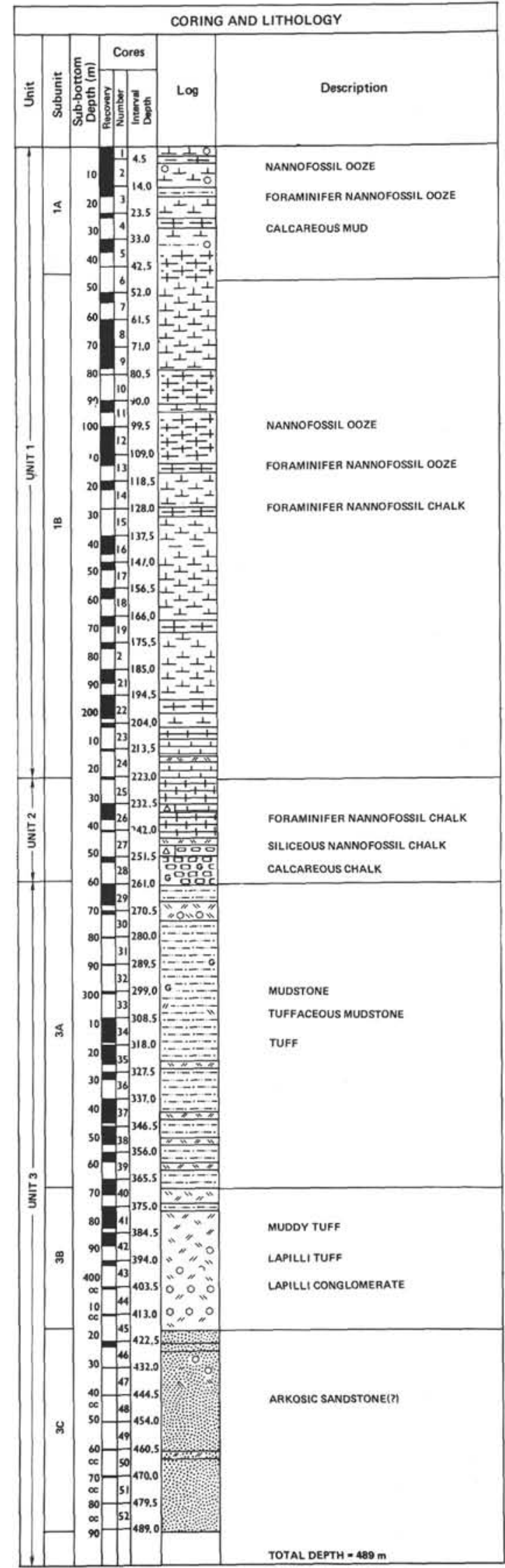

Figure 7. Lithological summary of Site 403. 


\section{Unit 1}

Sub-unit 1A: This sub-unit is characterized by marked fluctuations in $\mathrm{CaCO}_{3}$ content $(10-92 \%)$ which reflect an alternation of dominant lithologic types. In the upper 11 meters of the section, Quaternary in age, pale yellowish brown to very pale orange nannofossil ooze interbedded with moderate yellowish brown marly foraminiferal ooze is dominant. Interbeds average from 20 to $50 \mathrm{~cm}$ in thickness and the contacts appear to be gradational; the cores, however, were intensely disturbed by drilling. A distinct color change is evident at 11 meters, and the section below consists principally of alternating bluish white nannofossil ooze, light gray, marly foraminifer nannofossil ooze, and olive-gray calcareous mud. Here again the interbeds are 20 to $50 \mathrm{~cm}$ thick, but contacts between lithologic types are more commonly sharp. A suggestion of rhythmic alternation exists in Core 5 with white nannofossil ooze resting in sharp contact on calcareous mud and grading upward through marly ooze to calcareous mud. Limited bioturbation in the section is most evident just below the mud layers.

Compositions fluctuate widely in the section, particularly as regards quantity of calcareous biogenous remains and undifferentiated clay. Thus, the typical nannofossil ooze contains 75 to 85 per cent $\mathrm{CaCO}_{3}$, mostly nannofossils but with 10 to 15 per cent foraminifers, and the order of 5 per cent each of clay and siliceous biogenous remains. The marly oozes and foraminifer nannofossil oozes both are characterized by increased amounts of foraminifers, clay, and quartz, but generally have fewer siliceous remains. Nannofossils and foraminifers become scarce in the calcareous muds where clay and quartz prevail. The clay mineral suite is dominated by roughly equal parts of smectite and illite but contains a persistent small admixture of both chlorite and kaolinite.

Pebbles and terrigenous sand of all sizes occur sporadically throughout this unit, but are most common in Cores 2 to 5 . Most of the pebbles are one to two $\mathrm{cm}$ in diameter but range up to $5 \mathrm{~cm}$; a few appear faceted. Metamorphic lithologies, including quartzite, hornfels, amphibolite (?) and granulite, are most common among the pebbles, but graywacke sandstone, green calcareous mudstone, brown fossiliferous limestone, and vesicular basalt also were identified.

Sub-unit 1B: This sub-unit consists of nannofossil ooze and foraminifer nannofossil ooze. Foraminifer nannofossil ooze predominates in the upper part of the section (50-110 $\mathrm{m})$, nannofossil ooze in the middle part (110-190 m), and foraminifer nannofossil chalk prevails near the base. The change from ooze to chalk occurs at a depth of 200 meters according to visual observation of the cores, but the downhole sonic log suggests this change occurs at about 175 to 180 meters.

In terms of composition, the most distinctive feature of this sub-unit is its general uniformity compared to the remainder of the section at this site. The $\mathrm{CaCO}_{3}$ content averages about 90 per cent through the entire unit and does not fluctuate by more than \pm 5 per cent from the average. The most obvious variations in composition are in the nannofossil/foraminifer ratio. The nannofossil oozes typically contain 70 to 85 per cent nannofossils, 5 to 7 per cent foraminifers, 5 to 10 per cent clay, and a trace of siliceous microfossils, whereas the foraminifer/nannofossil oozes average about 45 to 60 per cent nannofossils and 25 to 35 per cent foraminifers. The clay mineral suite is dominated by smectite and illite which average about 50 per cent and 25 per cent, respectively, of the less than $2 \mu \mathrm{m}$ fraction. These vary sympathetically downhole with smectite showing a general increase in abundance where illite decreases. Kaolinite and chlorite occur throughout the sub-unit but generally comprise less than 10 per cent each and decline in abundance near the base.

Sediment color in this sub-unit is typically a rather uniform bluish white to very light gray, though occasional bands of bluish gray, pale green, and light olive-gray occur in some of the foraminifer-nannofossil oozes and small black streaks of pyrite are found throughout most of the section. In several cases (e.g., Cores 11, 14) the color bands reflect slight variations in texture which are related to foraminifer/nannofossil ratio and are suggestive of current lamination. Glauconite-filled foraminifers of Eocene age were found in a greenish band in Core 9 (upper Miocene) and a $10-\mathrm{cm}$ bed of marly nannofossil-foraminifer chalk in Core 24 contains up to 15 per cent of volcanic glass. Ice-rafted pebbles and coarse terrigenous sand are present down to Core 14 , but, Cores 8 through 14 show evidence of considerable disturbance and the presence of cavings from uphole. The lowermost ice-rafted materials considered to be definitely in place are in Core 5, which is upper Pliocene. Those in Cores 8 through 14 (late Miocene) are considered to represent downhole contamination.

\section{Unit 2}

The top of Unit 2 corresponds to a prominent hiatus between upper Miocene bluish white nannofossil chalk and late Oligocene grayish yellow-green foraminifer nannofossil chalk. A second prominent hiatus between middle Oligocene and middle Eocene occurs in the upper part of the unit and sediments at the base are early Eocene in age. Thus, within the sub-bottom depth interval of 223.5 to 260 meters corresponding to Unit 2, over $40 \mathrm{~m}$.y. of geologic history are spanned.

Greenish gray foraminifer nannofossil chalk and yellowish gray to pale orange siliceous/calcareous chalk are the dominant lithologies in Unit 2. Compared to the overlying Miocene section, these chalks contain less recognizable nannofossils, more unspecified carbonate (disaggregated nannofossils?), and more siliceous remains, principally radiolarians and sponge spicules. Siliceous remains reach their peak concentration $(25 \%)$ in the middle Eocene. Chlorite and kaolinite disappear from the clay mineral suite which is dominated by smectite with a small admixture of illite.

Near the base of the section (Cores 27, 28), interbeds of variable lithology, an abrupt drop in $\mathrm{CaCO}_{3}$ content, and marked variations apparent on the gamma-ray and sonic velocity logs reflect a transition to sediments characteristic of Unit 3. A 7-cm bed at the bottom of Core 27 consists of well-lithified vitric tuff. Basic (?) volcanic glass of silt size makes up 60 per cent of this sediment with most of the remainder composed of clay and unidentified opaque material. The tuff is clearly cross-laminated, indicative of ripple development and bottom transport. Core 28 consists 
principally of yellowish green chalk but, in contrast to overlying chalks, is very well laminated and crosslaminated in parts, intensely bioturbated in other parts, and contains a conspicuous admixture of coarse biogenous remains such as mollusk and crinoid fragments, echinoid spines, and sponge spicules. In places these are concentrated to form thin calcarenite layers. The entire core is glauconitic and near the base is a $3-\mathrm{cm}$ layer containing over 60 per cent glauconite along with 10 per cent siliceous biogenous remains and 10 per cent coarse silt- to sand-sized quartz.

\section{Unit 3}

This unit extends from a sub-bottom depth of 260 meters to the bottom of the hole $(499 \mathrm{~m})$ and ranges from lower Eocene to probable upper Paleocene. Most of the unit consists of interbedded and intermixed volcaniclastics and mudstone which have been categorized for the most part either as tuffaceous mudstone or muddy tuff depending upon which component dominates. Two main volcaniclastic "events" are recorded in the section. Tuffaceous material from the youngest event occurs in the upper part of Sub-unit $3 \mathrm{~A}$ (Cores 29 and 30) whereas that from the earlier event dominates most of Sub-unit $3 \mathrm{~B}$ and constitutes the main criteria for designating this as a sub-unit. Sub-unit $3 \mathrm{C}$ is relatively free of volcaniclastic debris. For details concerning the petrography of volcanogenic sediments at this and other sites on the Rockall Plateau, refer to Harrison et al., this volume.

Sub-unit 3A: The uppermost part of this unit (top Core 29) consists of greenish black glauconitic mudstone which records a transition downwards from the overlying unit. Worthy of note is the fact that $\mathrm{CaCO}_{3}$ content drops to near zero in this core, thus essentially completing a trend which is evident near the base of Unit 2 . Texturally, the mudstone varies from silty, very fine sand to sandy silt with an average clay component of about 10 to 20 per cent. The chief constituents of the mudstone include glauconite $(20-40 \%)$ and smectite $(40-60 \%)$, whereas the remainder is made up of quartz $(5-10 \%)$, sponge spicules $(10-15 \%)$, nannofossils $(5-10 \%)$, mica $(3-5 \%)$, and zeolite $(3-5 \%)$. Downward in Core 29, a progressive increase in the abundance of tuffaceous material is apparent and from the middle of Section 3 downward, volcanic ash and lapilli are the predominant constituents. The change portrayed by binocular microscope examination is one of occasional volcanic clasts "floating"' in a muddy matrix in the upper core to one of a framework of tuffaceous material with little mud matrix in the lower core. Accompanying this change is a corresponding decrease in the percentage of glauconite and quartz, an increase in both size and variety of volcanic clasts and, curiously, a progressive increase in abundance of megafossils, chiefly echinoid fragments and pelecypods. In Core 30 , volcaniclastics still predominate $(60-70 \%)$ but, by Core 31 , the percentage has diminished substantially and the prevailing lithology becomes dark gray to dark greenish gray slightly tuffaceous mudstone, which prevails through much of the remainder of the unit. The transition in lithology is clearly evident in the downhole sonic log with relatively low velocities at the top and through most of the lower unit corresponding to the mudstone and velocity peaks in Cores 20 and 30 which reflect the tuff layers.

In terms of composition, the mudstones in the lower part of the sub-unit are similar to those at the top except that glauconite becomes much less conspicuous where quartz, mica, and tuffaceous material become correspondingly more common. Smear slides and X-ray analyses on mudstones (Latouche et al., this volume) between Cores 32 and 40 indicate the following general composition: quartz (10-20\%), feldspar (10-20\%), mica (2-3\%), smectite $(30-50 \%)$, volcanic glass and lithic fragments $(15-25 \%)$, glauconite $(1-2 \%)$, zeolite $(5-10 \%)$, pyrite $(1-2 \%)$, and a persistent 1 to 2 per cent of fragmental plant remains, both translucent and opaque. $\mathrm{CaCO}_{3}$ amounts to less than 5 per cent, but a trace of nannofossils and megafossils was observed throughout the section. Heavy minerals identified in the smear slides include hornblende, augite, zoisite, epidote, titanite, and magnetite (?).

Distinct impression was gained by binocular microscope examination that the mudstones show a steady decrease in grain size downward if one excludes the volcanic detritus. Thus, whereas mudstones in Cores 30 to 34 are dominated by fairly well-sorted medium to coarse silt, the lenses and matrix of mudstone sandwiched within the tuffaceous material in Cores 38 to 40 are mainly olive-black silty clays. This size trend is accompanied by a change in the character of the sedimentary structures evident in the mudstone sequence. In the upper, more silty part of the unit, lamination and cross-lamination which reflect slight variations in silt/clay ratio are fairly common. Several examples of rather vague (ripple?) foreset lamination, one of flaser bedding, and a number of horizontal laminations on a millimeter scale were noted in Cores 34 to 36 . In all cases, the finer grained laminae are characterized by oriented mica flakes and wisps of detrital plant remains. Structures which are interpreted to reflect small-scale cut-and-fill are present in this interval as are a variety of contorted laminations believed related to bioturbation, gas escape, and perhaps soft sediment slumping or liquification. Deeper in the unit (Cores $38-40$ ) where tuffaceous material again becomes a prominent component of the section, sedimentary structures have a different aspect. Very common here are distorted and disrupted laminations of both claystone and fine tuffaceous material which appear to relate to input of coarse volcanic debris. Also common are graded layers of tuffaceous material. In general, these show normal grading from coarse tuff or fine lapilli up to fine muddy tuff or tuffaceous mudstone, but occasional inverse grading also was noted. Scale of the graded layers ranges from a few millimeters (base Section 37-3) to tens of centimeters (top of Section 40-1).

Sub-unit 3B: In the basal part of Sub-unit 3A, the amount of tuffaceous debris gradually increases at the expense of the incorporating mudstone and at a sub-bottom depth of about 368 meters (middle of Core 40), the volcanic component clearly becomes dominant so that the sediment is more appropriately termed a greenish black to olive-black muddy tuff. The change is indicated by an abrupt increase in the sonic velocity in the downhole log and by a sharp peak in the magnetic intensity. From this level to a sub-bottom 
depth of 415 meters, tuffaceous material predominates and serves as the main criterion for distinguishing Sub-unit 3B. In the upper part of the unit (down to Core 43), the vitric and lithic fragments comprising the tuff range from sand to granule in size and are angular. Mudstone matrix persists in this part of the section, in subordinate amounts, as do detrital plant fragments, pyrite, traces of glauconite, and fragmented megafaunal remains (chiefly pelecypods and gastropods). Notably the clay size fraction consists solely of poorly crystallized smectite and amorphous silica. Sedimentary structures are not conspicuous, but one sees evidence of graded bedding, occasional vague lamination, contorted lamination and bioturbation similar to the lower part of Sub-unit 3A.

Recovery was very poor in the lower part of this unit, but the meager bits of core available suggest an interbedded section of lapilli tuff (or lapilli conglomerate) and relatively soft muddy tuff and/or tuffaceous mudstone. Marked fluctuations in the downhole sonic log through this section support this. Velocity peaks correspond to the hard, calcite-cemented tuffs whereas lows reflect the intervening softer material. Notable also is the fact that peaks in the gamma-radiation log correspond to the sonic lows and presumably reflect the increased clay and abundance of organic matter witnessed in the softer layers.

Vitric and lithic fragments comprising the lapilli tuffs generally range between 4 and $8 \mathrm{~mm}$ and many are fairly well rounded. In Core 45 , the tuffaceous material occurs intermixed with subrounded to well-rounded granules of quartz, microcline and shell fragments indicating considerable reworking and mixing subsequent to its arrival at this site. Thin-section examination of this rock reveals that most of the lapilli are composed of turbid cryptocrystalline material which varies from pink to green to black. Many are at least slightly vesicular and some are highly so. A few lapilli are made up principally of crystal laths of andesine. This, coupled with the pale brown, low relief character of much of the glass, suggests the volcanism was primarily andesitic in nature.

Sub-unit 3C: The meager bits of core recovered near the bottom of the hole indicate that the quantity of tuffaceous material again drops off substantially and the section becomes dominated by alternating (?) unconsolidated muddy sand to fairly well-sorted, calcite-cemented sandstone. The first sign of the change is a small sandstone fragment observed in Core 45, however, the top of this sub-unit is picked at the position of a marked break in the downhole logs at a sub-bottom depth of 418 meters, between Cores 45 and 46 .

Core 46 , the uppermost in this unit, contains the following three distinct lithologies in order of increasing depth: (1) 0-60 cm - well-laminated tuffaceous siltstone; (2) 60 to $65 \mathrm{~cm}$ - lignitic mudstone; and (3) 65 to $115 \mathrm{~cm}$ - medium to very coarse unconsolidated sand.

The siltstone is olive-black in color and is characterized by well-developed lamination and cross-lamination. The coarser laminae range from 1 to $3 \mathrm{~mm}$ in thickness whereas finer grained laminae are generally one millimeter or less and contain oriented bits of mica and organic material. Smear-slide estimates (probably poor) indicate a composition of quartz (30\%), pale brown volcanic glass
$(25 \%)$, mica $(20 \%)$, lithic fragments $(10 \%)$, feldspar $(5 \%)$, and about 10 per cent clay. Hornblende is a conspicuous accessory.

The thin dusky yellowish brown mudstone which underlies the siltstone is texturally a silty clay which contains abundant opaque, fragmented plant remains. Shipboard measurements indicate this contains 5 to 6 per cent organic carbon and fragments of similar appearing material in the underlying sand contain as much as 12 per cent carbon, thus verging on lignite.

The upper part of the unconsolidated sand is badly disturbed, but immediately beneath the lignite this appears to be dominantly poorly sorted, medium to very coarse quartz with an admixture of volcanic ash and lapilli. Near the base of Core 46, fine to medium, moderately to well-sorted quartz sand, in graded beds the order of $1 \mathrm{~cm}$ thick, alternate with laminations of gray sandy mud. One thin lignitic layer a few millimeters thick also occurs in this section.

Recovery from the base of Core 46 to the bottom of the hole included : (1) a core catcher of unconsolidated medium to coarse arkosic(?) sand from Core 48 ; (2) fragments of dark greenish gray, fine to medium, subarkosic sandstone from Cores 50 and 51; and (3) a tablespoonful of soft sandy mud from Core 52 which well may be cavings.

The downhole sonic log through this section, which extends to the top of Core 50, suggests a sequence of well-consolidated sandstones (high velocity), the order of 3 to $5 \mathrm{~cm}$ thick alternating with poorly consolidated muddy sand or sandy mud (low velocity) intervals of similar thickness. A puzzling feature is the correlation of high gamma-ray values with the sandstones which may reflect concentration of radioactive material in lignitic fragments in the sandstone by connate waters.

\section{LITHOLOGY, SITE 404}

A total of 389 meters of section was drilled at Site 404 in sediments which ranged from the Quaternary to probably the late Paleocene. The limited recovery in the last three cores suggests that the oldest sediments penetrated are calcareous and tuffaceous conglomerates interbedded with sandstones and glauconitic mudstone. These beds are overlain by a probable deltaic sequence of carbonaceous to glauconitic mudstones, tuffaceous in part, with occasional interbedded sandstone and marly limestone, which range in age from Paleocene to early Eocene. A marked change in sedimentation conditions, reflecting deeper water and reduced terrigenous supply, is recorded by the accumulation of calcareous porcellanites from late-early Eocene into middle Eocene. A prolonged hiatus is present between the middle Eocene and late Miocene. In the late Miocene, a thick sequence of white nannofossil to foraminifer/ nannofossil ooze was deposited rapidly. The upper Pliocene and Quaternary section is characterized by alternating calcareous mud and marly foraminifer nannofossil ooze containing ice-rafted pebbles along with terrigenous quartz and feldspar.

Three main lithologic units and four sub-units are distinguished within the section. These are summarized in Table 4 and Figure 8 and, following, are described from the top down. 
TABLE 4

Lithologic Units, Site 404

\begin{tabular}{|c|c|c|c|c|c|}
\hline Unit & Sub-Unit & Cores & $\begin{array}{l}\text { Sub-Bottom } \\
\text { Depth }(. n)\end{array}$ & Lithology & Age \\
\hline \multirow[t]{3}{*}{1} & $1 \mathrm{~A}$ & $1-2$ & $0-28$ & $\begin{array}{l}\text { Marly foraminiferal/ } \\
\text { nannofossil ooze, } \\
\text { foraminiferal/nanno- } \\
\text { fossil ooze, } \\
\text { calcareous mud }\end{array}$ & Quaternary \\
\hline & 1B & $3-6$ & $104-199$ & $\begin{array}{l}\text { Nannofossil ooze, } \\
\text { foraminiferal/nannofossil } \\
\text { ooze }\end{array}$ & $\begin{array}{l}\text { Pliocene- } \\
\text { late Miocene }\end{array}$ \\
\hline & \multicolumn{5}{|c|}{ HIATUS } \\
\hline 2 & & $7-16$ & $199-294$ & $\begin{array}{l}\text { Calcareous porcellanites, } \\
\text { calcareous mudstone, } \\
\text { tuffaceous interbeds, } \\
\text { glauconitic mudstone }\end{array}$ & $\begin{array}{l}\text { Middle Eocene- } \\
\text { early Eocene }\end{array}$ \\
\hline \multirow[t]{2}{*}{3} & $3 \mathrm{~A}$ & 17.23 & $294-360.5$ & $\begin{array}{l}\text { Glauconitic mudstone, } \\
\text { tuffaceous mudstone, } \\
\text { sandstone, } \\
\text { marly limestone }\end{array}$ & $\begin{array}{l}\text { Early Eocene- } \\
\text { late Paleocene }\end{array}$ \\
\hline & 3B & $24-26$ & $360.5-389$ & $\begin{array}{l}\text { Sandstones, } \\
\text { calcareous tuffaceous } \\
\text { conglomerate }\end{array}$ & Late Paleocene \\
\hline
\end{tabular}

\section{Unit 1}

Sub-unit 1A: This sub-unit was sampled in two cores taken 12.5 meters apart and consists mainly of an alternation of light brown calcareous mudstone and very pale orange marly nannofossil ooze to pinkish gray foraminifer/nannofossil ooze. The principal lithologic variations of the sediment mainly reflect changes in the ratio of calcium carbonate to clay; the calcium carbonate content fluctuates from 20 to 80 per cent. The clay mineral assemblage is dominated by smectite and illite, but kaolinite and chlorite constitute a persistent 10 to 20 per cent each. Quartz and feldspars are present as are well-rounded pebbles $(4-40 \mathrm{~mm}$ in diameter) which occur sporadically throughout the sub-unit and consist of quartzite, hornfels, and granites. The diversity of rock species and the abundance of detrital minerals suggest an ice-rafted origin.

A dark greenish gray to black vitric tuff is present in Cores 2 to 6 ; refractive index measurements gave $\mathrm{n}=1.554$ for brown glass and $n=1.497$ for colorless shards indicating basaltic and rhyolitic sources respectively.

Sub-unit 1B: The sub-unit was sampled in four cores cut over the 104 to 199 meter depth interval. Cores 3 and 4 consist of bluish white nannofossil ooze and foraminifer/ nannofossil ooze containing exotic pebbles of mica-schist and hornfels that are interpreted to represent downhole contamination. Cores 5 and 6 consist of very light gray foraminifer/nannofossil ooze and nannofossil ooze. Occasional "gritty" zones due to increased foraminifer concentration are present. Near the base of Core 5, Section 2 the ooze is indurated to a nannofossil chalk that contains disseminated glauconite, pyrite, and plant fragments. Compositionally, sediments of this sub-unit differ from those in Sub-unit 1A in the following respects: a persistent high proportion of calcium carbonate $(\sim 80 \%)$, reduced content of kaolinite and chlorite which diminish downsection, and the absence of quartz and feldspars (Latouche, this volume).

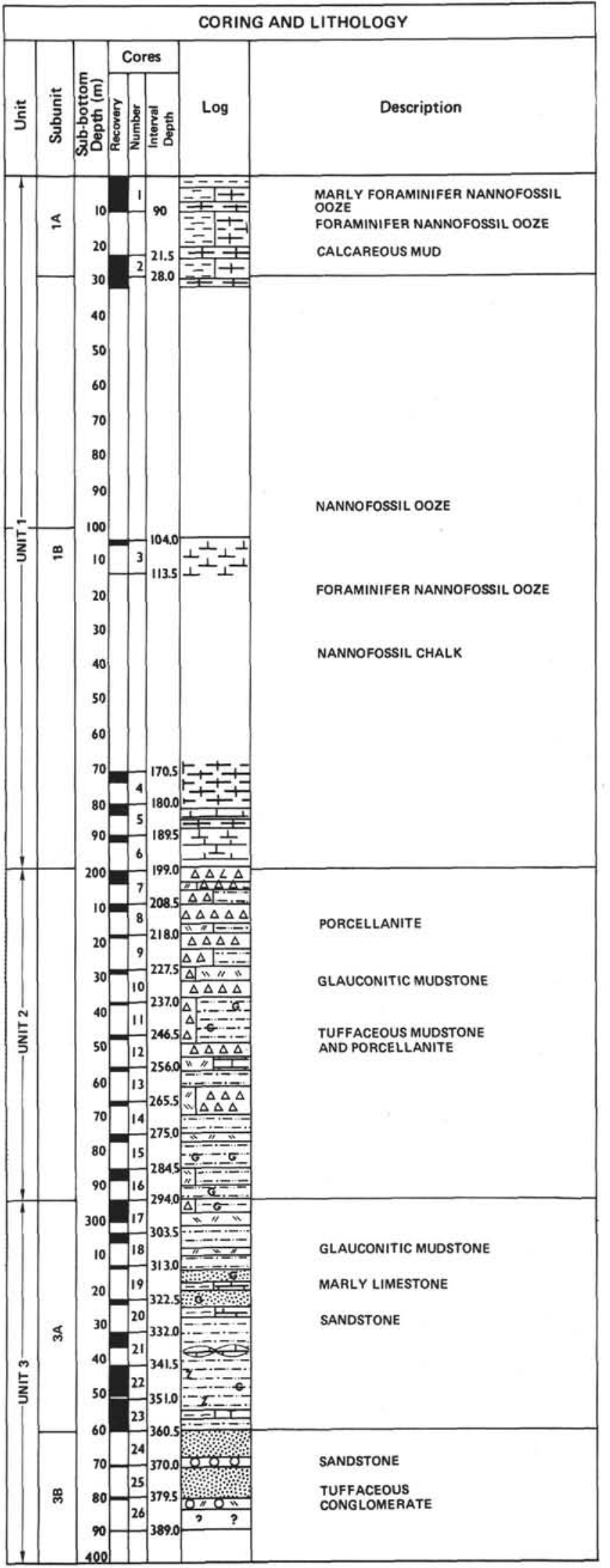

Figure 8. Lithological summary of Site 404. 


\section{Unit 2}

The boundary between Units 1 and 2 corresponds to the prominent hiatus between the upper Miocene bluish white nannofossil ooze and middle Eocene olive-yellow calcareous porcellanite. The lower boundary of Unit 2 has been drawn at the base of Core 16 which exhibits a transitional lithology toward that characteristic of Unit 3 and is also palynologically correlative with the base of Unit 2 at Site 403 (Costa and Downie, this volume).

Pale olive to dusky-green porcellanite, spicule-bearing mudstone, siliceous tuff, and glauconitic mudstone are the dominant lithologies in Unit 2. Compared to the overlying Miocene section, sediments of Unit 2 are richer in siliceous microfossils (chiefly sponge spicules and radiolarians) and much less calcareous. The clay mineral assemblage consists solely of smectite, well crystallized at the top and becoming poorly to very poorly crystallized toward the base. Clinoptilolite is frequently present and often abundant; quartz and feldspars (predominantly plagioclase) appear in small amounts near the base of the unit. A distinctive heavy mineral assemblage comprised of olivine $(0.5 \%)$ and augite $(99.5 \%)$, possibly derived from a basaltic source area, dominates most of Unit 2. Towards the base, however, in Core 16, Section 2 and Core 17, an assemblage comprised of diopside $(81.5 \%)$, hypersthene $(13 \%)$, apatite $(2.5 \%)$, garnet $(1 \%)$, zircon $(1 \%)$, tourmaline $(1 \%)$, biotite, and rare muscovite appears.

The upper part of the unit consists of interbedded calcareous porcellanite and spicule-bearing mudstone with occasional glauconite-rich, olive-gray tuffaceous porcellanite interbeds. Plain and cross-lamination are common and bioturbation is present throughout. The calcareous porcellanite comprising Core 11 is largely composed of sponge spicules with foraminifers and radiolarians of well-sorted sand grade. The tuffaceous porcellanite of Core 14 is similarly composed of well-sorted spicules, radiolarians, and foraminifers with well-sorted glass shards set in a clayey matrix. The glass $(25 \%)$ has a refractive index higher than 1.57 indicating a basaltic affinity. Glauconite and mudstone become increasingly abundant towards the base of the unit and reflect a transition to lithologies characteristic of Unit 3. The glauconite forms ooliths, pseudo-ooliths, irregular pellets, and micaceous flakes that are associated with other micas. Irregular and microenterolithic patches of glauconite may accompany ooliths and replace or penetrate other constituents such as radiolarians and the central axes of sponge spicules. A thin-section study of the tuffaceous mudstone in Sample 16-2, $147 \mathrm{~cm}$ showed rounded pellets and fragmental glauconite which is microcrystalline with botryoidal structure. Microfossils are predominant with sponge spicules, foraminifers, radiolarians, and collophane scraps. The fine sand and silt fraction consists of fresh angular plagioclase grains and quartz. The pyroclasts (Harrison et al., this volume) are feldspar/microlitic lava particles $(0.1$ $\mathrm{mm}$ ) set in a matrix of microcrystalline calcite with some clay, interstitial bioclasts, and granular opaque oxides. Within Unit 2, a total of eight tuffaceous interbeds were cored although tuffaceous material is liberally sprinkled through much of the section.

\section{Unit 3}

Most of Unit 3 consists of glauconitic mudstone with interspersed sandstones, marly limestones, and volcaniclastics. In comparison to Unit 2, Unit 3 is characterized by more quartz, a decrease in calcareous and siliceous organisms, a predominance of poorly crystallized smectite, and a distinctively different heavy mineral assemblage which consists predominantly of hornblende $(68.5 \%)$ and epidote (18\%) (Harrison et al., this volume). Carbonaceous material and pyrite nodules are also common in parts of Unit 3.

Sub-unit 3A: The uppermost part of Sub-unit 3A (Cores 17 and 18) consists of glauconitic mudstone and siliceous mudstone that is transitional with the base of Unit 2. The base of Sub-unit $3 \mathrm{~A}$ has been defined by the change from mudstones to sandstones at the base of Core 23 .

The tuffaceous glauconitic mudstone comprising the upper part of Sub-unit $3 \mathrm{~A}$ includes silty sand, sandy silt, and silty clay. These contain common fragmented megafaunal remains, and typically are bioturbated. A thin-section study of the siliceous, glauconitic mudstone comprising Section 17-1 shows an abundance of angular resistates (chiefly quartz and alkali feldspar along with mica and sponge spicules) which are poorly sorted and average about $0.9 \mathrm{~mm}$. Rounded glauconite pellets up to $1.5 \mathrm{~mm}$ across are common. The matrix contains specks of zeolite (clinoptilolite) up to $0.1 \mathrm{~mm}$ across, hornblende, and much chloritic material. The glauconitic mudstone of Core 17 passes down into a tuffaceous glauconitic mudstone that becomes more sandy toward the base marking increased quartz and feldspar. The tuff found in Section 18-2 is petrographically similar to tuffs from Cores 30 and 35 of Site 403 and contains reworked pyroclasts with subordinate orthoclasts; the volcanic glass has a refractive index of 1.55 suggesting a basaltic composition.

Fine-grained, glauconitic sandstone interbedded with marly limestones is present through the depth interval of 313 to 332 meters (Cores 19 and 20). The sandstones are composed chiefly of quartz, feldspar, and glauconite, poorly to moderately sorted and calcite cemented. Tuffaceous material is conspicuous in parts. Mudstone, generally greenish black to dark greenish gray, again predominates in the lower part of the sub-unit (Cores 21 to 23). These contain occasional interbeds and nodules of marly limestone. Streaks of fragmental plant debris, pyrite, and zeolite (clinoptilolite) are common through most of this section; glauconite and coarse tuffaceous material occur sporadically. Fragmented mollusk remains are conspicuous in Core 23. Compared mineralogically to mudstones in the overlying section, these are richer in quartz and feldspar (chiefly plagioclase) and contain illite as well as smectite (largely poorly crystallized) in the clay mineral assemblage. Texturally, the mudstones consist chiefly of firm sand and coarse silt and they show common evidence of plane and cross lamination as well as bioturbation. Sandy beds are present near the base (Core 23) indicating a transition to Sub-unit 3B.

Thin-section study of the mudstones in Cores 22 and 23 show the common occurrence of angular, sand-sized (0.06$0.09 \mathrm{~mm}$ ) grains of quartz, microcline, and oligoclase, 
along with micas, bioclasts, and argillized pyroclasts. Glauconite is present as ooliths and pseudo-ooliths. The clay matrix contains zeolites, microframboidal pyrite, and carbonaceous filaments.

Sub-unit 3B: The limited recovery below Core 23 indicates the dominant lithology near the bottom of the hole is sandstone with interbedded conglomerate and minor (?) glauconitic mudstone. The sandstones are mainly fine- to medium-grained and consist chiefly of quartz, mica, and lithic fragments with relatively minor feldspar, glauconite, and zeolite. Granule-sized lithic fragments found in Core 25 include quartzite and sandstone, basalt, schist, and hornfels . The tuffaceous conglomerate of Core 26 contains lapilli and shell fragments including one large fragment of an oyster shell.

\section{BIOSTRATIGRAPHY}

\section{Site 403}

Coring was continuous from sea floor to 489 meters at Site 403 , and Neogene foraminifer/nannofossil ooze and a thick sequence of Eocene and Paleocene volcaniclastic sediments were recovered (Figure 9). The Neogene sediments contained abundant, excellently preserved microfossil assemblages from a high latitude which, unfortunately, did not contain all the marker species that give the more precise stratigraphic resolution in tropical areas. This difference in assemblages on one occasion (upper to lower Pliocene boundary) caused slightly different age assignments based on foraminifers and nannofossils.

Sedimentation appears to have been continuous throughout late Miocene to Recent time. A uniform, pure white, upper Miocene nannofossil ooze is present from Core 8 to the base of Core $24(61.5-223 \mathrm{~m})$. All but one of these 18 cores contain nannofossils assigned to the long-ranging Zone NN 11, and foraminifers evenly distributed throughout Zones N.18 to N.16. The exceedingly high upper Miocene sedimentation rate was probably due to the influx of the fine fraction that had been winnowed from other places. Numerous reworked upper Eocene planktonic foraminifers are present.

Most of the Neogene sediments tended to fluidize upon recovery, affording little opportunity for detailed analysis; in particular, no paleomagnetic measurements could be conducted. Thus, a unique opportunity to establish an absolute bio- and chronostratigraphy for high latitudes was lost.

A hiatus of nearly $15 \mathrm{~m} . \mathrm{y}$. separates a short section of upper Oligocene sediments in Core 25 from the overlying upper Miocene.

A 15 to $25 \mathrm{~m} . \mathrm{y}$. hiatus is recorded between Cores 25 and 26. Middle Eocene foraminifer marl and glauconitic sand occur in Cores 26 and 27. This marl is rich in diatoms and radiolarians; the same occurrence was found in sediments of the same age in previous DSDP sites in the North Atlantic. A hiatus of $3.8 \mathrm{~m}$.y. between Cores 27 and 28 is indicated by nannofossils. Unfortunately, the scarce, poorly preserved foraminifers of Core 28 failed to resolve this time interval.

A sequence of terrigenous and volcaniclastic sediments occurs from Core 29 to Core 52 , at a depth of 489 meters, where drilling terminated. These sediments are essentially

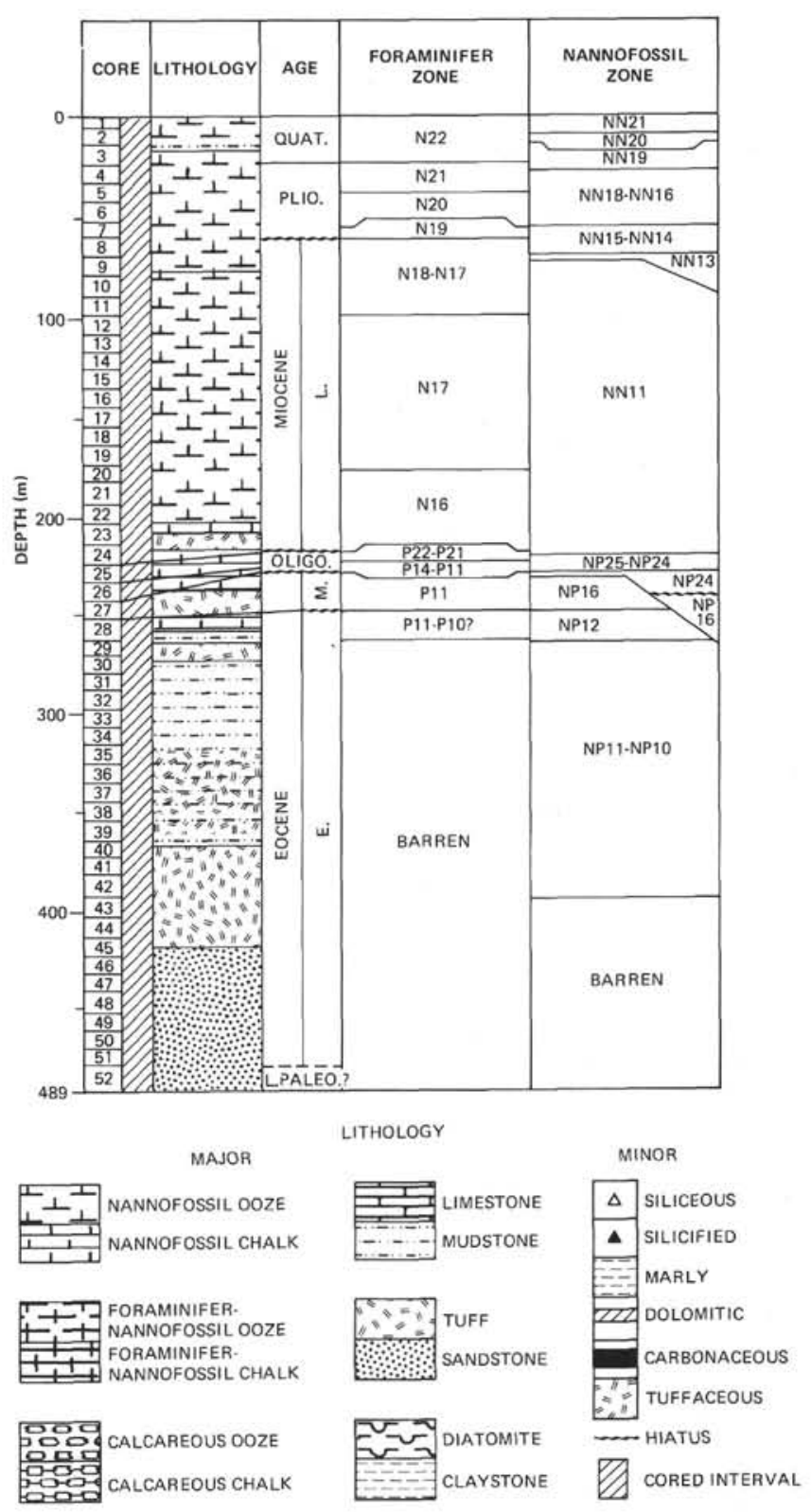

Figure 9. Biostratigraphic summary of Site 403.

barren of calcareous microfossils. Nannofossils contained in a few samples date this sequence as early Eocene. Foraminifers and ostracodes were recovered on occasion, but were so poorly preserved that they did not indicate much beyond a marine habitat, an interpretation also supported by calcareous worm tubes, fecal pellets, and crustacean fragments in Core 35. The sequence was entirely barren of calcareous microfossils below Core 40 . Some dates, however, were obtained by use of palynomorphs including dinoflagellates. Core 25 yielded poor material of no diagnostic value suggestive of the upper Miocene. Core 29 contained abundant lower Eocene species. Cores 34 to 40 yielded lower Eocene to upper Paleocene dinoflagellates. Cores 42 and 46 yielded poor assemblages, consistent with an upper Paleocene interpretation.

The benthic foraminifers of the entire Neogene section indicate deposition in a bathyal environment. The most 
typical indicator species of abyssal North Atlantic conditions, Epistominella exigua, is absent. The same environment of deposition was indicated for the Oligocene section and the foraminifer marl of Cores 26 and 27. An upper bathyal environment was indicated for the sediments of Core 28 , and the underlying clastic series was probably laid down in shallow, inner shelf to coastal waters. Palynological analysis indicates a late Paleocene to early Eocene deltaic environment which became progressively more marine, probably by flooding of the delta, upwards in the section to the early Eocene upper bathyal conditions. Analysis of the ostracode faunas agrees with the paleobathymetry established by benthic foraminifer and dinoflagellate analyses (Costa et al., this volume).

\section{Foraminifers}

An upper Pleistocene to upper Miocene (Zone N.16) nannofossil-foraminifer ooze occurs in Cores 1 to 24 . Pleistocene sediments contain abundant assemblages of well-preserved foraminifers, mainly planktonic, dominated by Globorotalia inflata, Globigerina bulloides, and Globigerina pachyderma. About 1 per cent benthic foraminifers are present indicating a lower bathyal environment.

The boundary between the Pleistocene and the uppermost Pliocene is placed at the bottom of Core 3 where the first Globorotalia tosaensis, with transitional forms between Globorotalia truncatulinoides and Globorotalia tosaensis s.s., occurs. According to Berggren (1970) the appearance of Globigerina atlantica in Core 4 indicates that Pliocene sediments were reached.

Within the interval from Cores 4 to 8 , Globorotalia crassaformis and the first Globigerina praebulloides occur together in Sample 8, CC. This apparently is the boundary between lower Pliocene and upper Miocene sediments. The benthic foraminifer assemblage (about 1 per cent of the total foraminiferal fauna) indicates a lower bathyal environment. Sample 5, CC contains 3.3 per cent benthics dominated by Globocassidulina subglobosa which indicates cold lower bathyal water.

Uppermost Miocene (Zone N.18 to top of Zone N.17) is represented down to Core 11 where Globorotalia margaritae and Globorotalia pleisiotumida are present. Numerous reworked upper Eocene planktonic foraminifers, such as Globigerapsis index and Globorotalia centralis, are present.

Upper Miocene sediments (Zones N.17 to N.16) were recovered in Cores 12 to 24. The presence of Globorotalia merotumida in Sample 20, CC indicates that the boundary between Zones N.17 and N.16 is in Core 20.

Throughout this entire upper Miocene sequence benthic foraminifers remain scarce ( 1 to 2 per cent of the total foraminiferal fauna) and indicate a lower bathyal environment. The planktonic foraminifer assemblages often show low diversity which may be due to cold water.

Within Sample 25, CC occurs an important change. Foraminifers are scarce and their preservation is moderate but radiolarians are abundant, indicating dissolution. Benthic foraminifers are more abundant $(6.6$ per cent of the total foraminiferal fauna) and indicate a bathyal environment. The presence of Chiloguembelina indicates an
Oligocene age (nannofossil and palynological age determinations agree fairly well), but Globigerinoides primordius also occurs, indicating latest Oligocene time. Thus there is evidence that the first appearance of Globigerinoides is in the upper Oligocene and not at the boundary between the Oligocene and Miocene. The absence of at least the middle and lower Miocene section marks an important hiatus.

Another hiatus is marked between Samples 25, CC and 26 , CC. Sample 26 , CC contains a poorly preserved assemblage of heavily encrusted middle Eocene planktonic foraminifers (Globigerapsis index, Globigerina senni, Globorotalia rohri), a few benthic foraminifers, and common radiolarians. At least the lower Oligocene and upper Eocene are absent. Core 27 contains a middle Eocene planktonic foraminifer assemblage dominated by Globigerina boweri and also containing Globorotalia bullbrooki and Globorotalia centralis (Zone P.11). Benthics comprise less than 1 per cent of the foraminifer fauna. Glauconite is abundant in Sample 28, CC, forming numerous casts of radiolarians, diatoms, and foraminifers. Benthic foraminifers, which comprise more than 50 per cent of the total foraminiferal fauna, indicate an upper bathyal environment. The planktonic foraminifers are middle Eocene (Zones P.11 to P.10).

From Core 29 to the bottom of the hole, most of the samples are barren of foraminifers. Occasionally, poorly preserved benthic foraminifers (often casts) were found which indicated a shallow water environment. The presence of abundant volcanic vesicular glass fragments indicates a volcano-sedimentary formation. Core 35 , Section 3 contained three pieces of crustacean claws. Core 38 contained fecal pellets and possibly crustacean coprolites, and small worm tubes occurred in several samples near the bottom of the hole.

\section{Nannofossils}

Pleistocene sediments were recovered in Core 1 to Core 4 $(0-33.0 \mathrm{~m})$. The Emiliania huxleyi Zone (NN 21) occurs from Core 1 to Sample 2-3, 41-42 cm, the Gephyrocapsa oceanica Zone (NN 20) from Samples 2-3, $49-50 \mathrm{~cm}$ to 2 , CC. Core 3 and Core 4 , Section 1 belong to the Pseudoemiliania lacunosa Zone (NN 19).

Sediments are rich in well-preserved nannofossils. Reworked species from the Cretaceous are rare in some samples. Few diatoms occur in Cores 1 and 2. Coccolithus pelagicus, Cyclococcolithus leptoporus, and the small variety of Gephyrocapsa oceanica are the most frequent upper Pliocene species. Pseudoemiliania lacunosa, Coccolithus doronicoides, Discolithina japonica, and Pontosphaera pacifica are abundant within the Pseudoemiliania lacunosa Zone (NN 19).

The Pliocene/Pleistocene boundary is recognized by the disappearance of Cyclococcolithus macintyrei between Samples 4-1, 98-99 $\mathrm{cm}$ and 4, CC.

The sequence from Samples 4, CC to 6, CC (33.0-52.0 $\mathrm{m})$ belongs to the upper Pliocene (Discoaster surculus to Discoaster brouweri Zone, NN 16/NN 18). A subdivision of this interval is not possible because of the scarcity or absence of discoasters. Discoaster brouweri occurs sporadically in Samples 5-3, 45-46 cm and 5, CC. 
Sediments are rich in well-preserved to slightly etched nannofossils. Diatoms and silicoflagellates are rare in almost all samples. Coccolithus pelagicus, Cyclococcolithus macintyrei, Coccolithus doronicoides, Pseudoemiliania lacunosa, and Syracosphaera pulchra are abundant. A distinct decrease of Pontosphaera pacifica and Discolithina japonica is observed within the uppermost Pliocene.

Discoasters and scyphospheres are more frequent in the sediments of the lower Pliocene of Cores 7 and 8 (52.0-71.0 $\mathrm{m})$, which indicates higher water temperatures. Samples $7-1,67-68 \mathrm{~cm}$ to $8-3,128-129 \mathrm{~cm}$ belong to the stratigraphic interval of the Discoaster asymmetricus/Reticulofenestra pseudoumbilica Zone (NN 14/NN 15). A subdivision of these two zones is not possible because of the absence of Ceratolithus tricorniculatus.

The Ceratolithus rugosus Zone (NN 13) occurs from Samples $84,49-50 \mathrm{~cm}$ to probably 8, CC. A few specimens of Ceratolithus rugosus are present. Discoaster pentaradiatus is small and also the bifurcations at the ends of the rays are not very distinct, which is caused by lower water temperatures. Nannofossils are abundant; they are slightly etched in the lower part of this sequence. Diatoms and silicoflagellates occur in all samples.

The Discoaster quinqueramus Zone (NN 11) of the upper Miocene is extremely thick $(71.0-223.0 \mathrm{~m})$. It includes the sequence from Samples 9-1, 46-48 $\mathrm{cm}$ to 24 , CC. Fluctuations in the abundance of discoasters and of the CCD within this zone indicate fluctuations of the water temperatures. Sediments are rich in nannofossils. Their preservation varies from well preserved to more or less strongly etched. Discoasters are often slightly overgrown. Diatoms and silicoflagellates in general are scarce throughout this sequence. Reworked species from the Eocene are present in several samples. Ceratolithus tricorniculatus occurs sporadically; Sphenolithus abies and discoasters are scarce because of low water temperatures in high latitudes.

A hiatus, which represents an interval of about 18 m.y., lies between Cores 24 and 25. Middle and lower Miocene sediments are absent. The upper Miocene is underlain by the middle-upper Oligocene (Sphenolithus distentus/ Sphenolithus ciperoensis Zone (NP 24/NP 25) which is determined from Samples 25-1, 21-22 cm to 26-3, 45-47 $\mathrm{cm}$. Sediments are rich in nannofossils which are etched and partially broken. Some reworked species from the Eocene are present in several samples. Sphenoliths are absent from Oligocene deposits.

Another hiatus exists between Samples 26-3, $45-46 \mathrm{~cm}$ and 26-3, 130-131 cm representing an interval of about 13 m.y., and includes the upper Eocene and lower Oligocene. The middle Eocene (Discoaster taninodifer Zone, NP 16) occurs from Samples 26-3, 130-131 cm to 27, CC $(236.0-251.5 \mathrm{~m})$. Siliceous microfossils as well as nannofossils are common. The preservation is moderate to poor.

A hiatus, representing an interval of about $5 \mathrm{~m} . \mathrm{y}$. lies between the Discoaster taninodifer Zone (NP 16) and the Marthasterites tribrachiatus Zone (NP 12) of the lower Eocene. It includes the upper part of the lower Eocene and a part of the middle Eocene. The Discoaster taninodifer Zone
(NP 16) is underlain by the Marthasterites tribrachiatus Zone (NP 12) which occurs from Samples 28-1, 11-12 cm to $28, \mathrm{CC}$. Nannofossils are abundant; they are overgrown and broken. Species of the genus Toweius are frequent; Marthasterites tribrachiatus and Discoaster lodoensis are rare.

Samples from Core 29 to Core 42, Section 1 $(261.0-394.0 \mathrm{~m})$ are poor in nannofossils. The whole sequence belongs to the Marthasterites contortus/ Discoaster binodosus Zone (NP 10/NP 11) of the lower Eocene. Marthasterites tribrachiatus is missing from Samples $34-4,45-46 \mathrm{~cm}$ to 41 , CC. A few specimens of Marthasterites bramlettei occur in several samples. This species is typical for the nannoplankton Zone NP 10. According to this observation, the boundary between the two zones probably lies in Core 34 , Section 3 on the basis of the last occurrence of Marthasterites bramlettei in Sample $34-3,45-47 \mathrm{~cm}$.

Other species are: Coccolithus pelagicus, Chiasmolithus bidens, Transversopontis pulcher, Zygolithus dubius, Discolithina fimbriata, Sphenolithus primus, Zygodiscus plectopons, and Ellipsolithus macellus. Discoasters are present sporadically. Nannofossils are well preserved. Their scarcity may be due to dilution by the high amount of terrigenous material.

The sediments from Core 42 to Core $52(384.0-489.0 \mathrm{~m})$ are barren of nannofossils.

\section{Palynomorphs and Dinoflagellates ${ }^{2}$}

Cores 46 to 42 are upper Paleocene. Mixed, cuticular, and tracheidal debris dominate throughout. Terrestrial pollen and spores are abundant, with taxodiacean and conifer pollen predominating. Dinocysts are few but consistent with a Paleocene age. The environment was littoral, possibly deltaic.

Cores 41 to 35 (Zones Ia, Costa and Downie, in press) show some increase in the number of dinoflagellate cysts, indicating a slight increase of marine influence. Apectodinium is common in these assemblages, which are of upper Paleocene to lower Eocene. Terrestrial material predominates. Pediastrum sp., a fresh-water Chlorophyta, occurs in small quantities throughout this interval.

Cores 34 to 29 yield lower Eocene dinocyst assemblages of Zone Ib. Wetzeliella meckelfeldensis first appears in Section 34-5. The proportion of dinocysts increases markedly in Core 29, indicating initial flooding of the littoral zone. An abundance of Micrhystridium, Spiniferites, and Cyclonephelium compares closely with the early shallow water transgression of the London Clay.

Cores 28 and 26 are barren of palynomorphs.

Core 25 is poor in pollen and contains a practically monospecific dinocyst assemblage of Spiniferites cf. pseudofurcatus; the presence of Tectatodinium pellitum indicates an age not older than late Eocene.

Cores 18 and 19 yield dinocyst assemblages of Zone VIII. Core 3 yields a rich assemblage of Pleistocene type (Zone IX).

\footnotetext{
${ }^{2}$ Contribution by Lucy I. Costa and Charles Downie, Geology Department, The University, Mappin Street, Sheffield S135D, United Kingdom.
} 
Reworking was not observed in the Paleocene and Eocene samples; some reworking of Eocene material occurs in Core 25 and becomes common in Core 18 and, more especially, Core 9 . The assemblage of Core 3 is dominated by reworked material, of which Upper Cretaceous and Eocene elements are prevalent.

The Thermal Alteration Index of palynomorphs is generally low (1.5-2), but, in Section 42-1, it rises to 4 , indicating temperatures around $350^{\circ} \mathrm{C}$ and a local high heat source.

\section{Ostracodes}

The upper Miocene to Recent is represented by an ostracode fauna essentially composed of: Henryhowella asperrima, Bradleya dictyon, Poseidonamicus, and Krithe with less frequent Agrenocythere, Bairdia, Cytheropteron sp. 26, Echinocythereis echinata, and Thalassocythere acanthoderma. The upper Miocene is relatively rich in this diversified fauna, but in the upper Pliocene and Quaternary section, this fauna is considered depleted.

The Eocene fauna is poor, consisting only of Burtonia, Argilloecia, and Trachyleberidea prestwichiana. The Paleocene (Core 43) is represented by Hazelina(?).

\section{Site 404}

The upper 150 meters were spot-cored at Site 404 in order to reach the lower Eocene-Paleocene objective. Coring was then continuous from 150.5 meters to the bottom of the hole at 379.5 meters. Well-preserved Pleistocene, Pliocene, and Miocene calcareous microfossils from foraminifer/ nannofossil oozes were recovered from the top 199 meters. Middle Eocene siliceous and calcareous mudstones from 199 to 227 meters contained a poorly preserved calcareous microfauna and flora. Siliceous microfossils, such as radiolarians, diatoms, and sponge spicules were common or abundant.

The remainder of the section was lower Eocene and upper Paleocene and consisted of a succession of volcaniclastic, glauconitic, terrigenous, and biogenous sediments. From the top to the bottom of this sequence, the foraminifers showed progressively more severe signs of glauconitization and/or mechanical abrasion. Planktonic foraminifers were absent from 290 meters downwards; benthic foraminifers were absent from 302 to 351 meters. Nannofossils show a similar trend, becoming progressively scarcer downhole (absent in the two bottommost cores), and are represented by heavy, dissolution-resistant species.

Two significant gaps exist in this record. The first, between the upper Miocene and the middle Eocene, represents a hiatus of about $32 \mathrm{~m} . \mathrm{y}$. The second, between the middle and lower Eocene, is of lesser magnitude, about 4 m.y. (Figure 10).

The record of the benthic foraminifers indicates lower bathyal depths for Site 404 from the Holocene back to late Miocene time. The only indication of a change during the late Miocene is an increase in upper bathyal to shelf-edge specimens, and an increase in the relative abundance of benthic foraminifers downhole. Middle Eocene sediments contain a mixture of bathyal and upper slope species, suggesting an upper bathyal depth of deposition, if the assemblage is autochthonous. Should the fauna be a mixture of autochthonous deep water and allochthonous upper slope

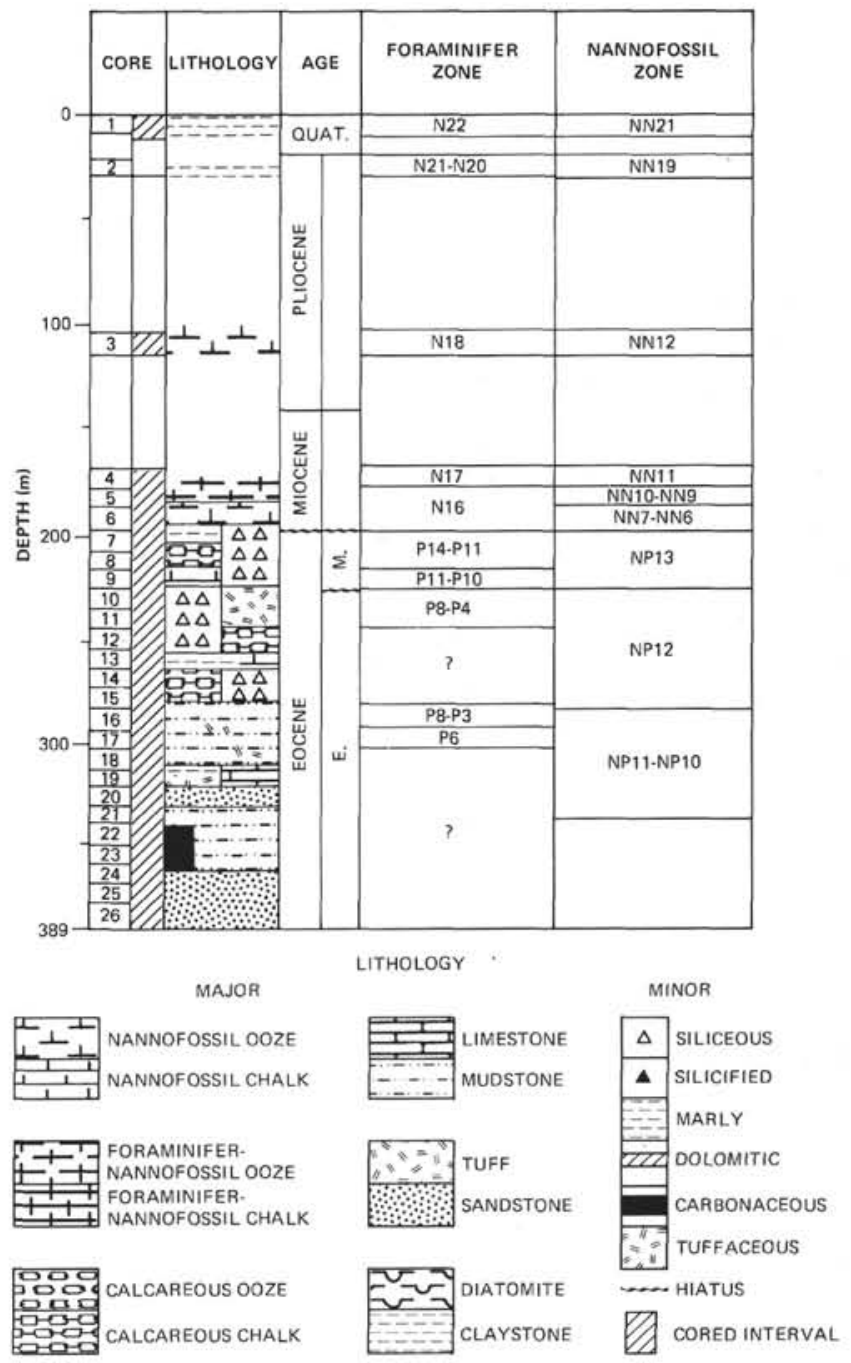

Figure 10. Biostratigraphic summary of Site 404.

specimens, then depth of deposition could correspond to a lower continental slope type of deposition. No deep water species are present in the lower Eocene samples. They contain, however, abundant planoconvex specimens of Cibicides, normally found in shallow water where they grow attached to submerged vegetation. Below the barren zone (302 to $352 \mathrm{~m}$ ) a sparse fauna contains forms common with the lower Eocene "London Clay" or "Varengeville" formation which is considered to represent a shallow $(<100$ m) water deposit.

Palynomorphs and dinoflagellates from the lower part of the hole indicate a late Paleocene deltaic environment with some marine elements. The early Eocene was marked by a flooding of the delta and a shallow marine environment equivalent to the middle to upper London Clay (Costa and Downie, this volume). The ostracode fauna indicates a similar bathymetric evolution of this site as the foraminifer fauna (Peypouquet, this volume).

\section{Foraminifers}

Sample 1, CC (9 m) contains an abundant, wellpreserved Pleistocene foraminifer assemblage (Zone N.22) with scarce Globorotalia truncatulinoides and abundant Globigerina bulloides and Globorotalia inflata. Benthic 
foraminifers are sparse (less than 1 per cent of the foraminiferal fauna) and indicate a lower bathyal environment.

Sample 2, CC $(28 \mathrm{~m})$ shows common Globorotalia tosaensis, $G$. crassaformis, and abundant $G$. inflata. The presence of $G$. tosaensis indicates uppermost Pliocene. Some Pulleniatina primalis are present which seems to indicate proximity to the shelf. Benthic foraminifers are more numerous but remain sparse.

Sample 3 , CC $(105 \mathrm{~m})$ is near the Pliocene/Miocene boundary (Zone N.18). The planktonic foraminifer assemblage contains Globigerina bulloides, $G$. riveroae, Globorotalia miocenia, G. crassula, and G. plesiotumida. Benthic foraminifers are sparse (less than 1 per cent), but indicate a bathyal environment.

Cores 4 to 6 contain upper Miocene planktonic foraminifers (Zones N.17 to N.16). From Core 4 (175 m) downward, the hole was continuously cored. Core 6 contains frequent Globorotalia tosaensis together with Globorotalia pseudomiocenica, G. pleisiotumida, and abundant Globigerina praebulloides.

A hiatus occurs between Samples 6, CC and 7, CC. Middle Eocene foraminifers are in Sample 7, CC. The assemblage of this core is poor and not well preserved. Sponge spicules are abundant, and radiolarians and especially diatoms are common. Planktonic foraminifers are small and misshapen. Globorotalia rohri is present. The sparse benthics indicate an upper bathyal to outer-shelf environment.

Sample 9, CC also contains middle Eocene planktonics $G$. rohri, Globigerina boweri) in a poor state of preservation. Benthic foraminifers comprise about 40 per cent of the total foraminiferal fauna. The presence of Buliminella and Trifarina could indicate an upper bathyal environment. There is a discrepancy between the ages determined by foraminifers and nannoplankton in this core. Nannoplankton species are lower Eocene.

Sample 10, CC contains abundant sponge spicules. The presence of planoconvex Cibicides, a benthic foraminifer genus, which grow attached to algae, bryozoa, or marine grasses, indicates a shelf environment. Planktonics are few and small. All Globigerina are lower Eocene to upper Paleocene (Zones P.8 to P.4), and are of the Globigerina linapertura-G. triangularis group. Sample 11, CC contained a similar assemblage.

The sediment in Cores 12 to 15 was hard and the microfauna unidentifiable.

Cores 16 and 17 , especially Core 17 , contain a relatively good assemblage of benthic foraminifers. Cibicidiinae are the most frequent, mainly Cibicidoides propius. Nodosariids, lenticulinids, Lagena, Globocassidulina, and Globulina are present. Bolivinopsis adamsi and Pulsiphonina prima were also found. This assemblage of benthic foraminifers has species common with the fauna of the lower Eocene "London Clay"' and "Varengeville", formations. Also present are ostracodes similar to those of the lower Eocene and upper Paleocene, and echinoid spines, a good indicator of shallow water.

The "London Clay" formation has been interpreted to have been deposited in a shallow (less than $100 \mathrm{~m}$ ), probably deltaic or inner-shelf environment. Planktonic foraminifers are sparse (maximum of $26 \%$ of the foraminif- eral fauna), always of the Globigerina linaperturatriangularis group, and small, indicating transport into the site of deposition.

Cores 18 to 25 are either barren or contain benthic assemblages similar to, but less abundant than, Core 17 (Cores 23 and 25). It thus appears that the entire lower Eocene-upper Paleocene section was deposited in a shallow inner shelf, probably deltaic, environment.

\section{Nannofossils}

Core $1(0-9.0 \mathrm{~m})$ contains forms belonging to the Emiliania huxleyi Zone (NN 21) of the Quaternary. Well-preserved nannofossils are abundant; a few reworked species from the Cretaceous and Eocene are present in almost all samples. They are more frequent in Sample 1-4, $62-64 \mathrm{~cm}$, whereas autochthonous nannofossils are scarce. Coccolithus pelagicus, Cyclococcolithus leptoporus, Emiliania huxleyi, and the small variety of Gephyrocapsa oceanica are abundant.

The Pseudoemiliania lacunosa Zone (NN 19) occurs in Core $2(21.5-28.0 \mathrm{~m})$. The most important species are Coccolithus pelagicus, Discolithina japonica, Pontosphaera pacifica, Cyclococcolithus leptoporus and Pseudoemiliania lacunosa. Nannofossils are abundant and are well preserved.

Core 3 contains the lower Pliocene Ceratolithus tricorniculatus Zone (NN 12) although only one specimen of Ceratolithus tricorniculatus was found along with Discoaster brouweri, D. pentaradiatus, and D. surculus. Nannofossils are abundant and partially broken; discoasters are rare. The Discoaster quinqueramus Zone (NN 11) of the upper Miocene occurs in Core 4 (170.5-180.0 m). The sediments are rich in slightly etched nannofossils. Coccolithus pelagicus and Reticulofenestra pseudoumbilica are the most frequent species. The abundance of discoasters is variable and they are slightly overgrown.

Core 5 probably represents the stratigraphic interval of the Discoaster hamatus/Discoaster calcaris Zone (NN 9/ $\mathrm{NN} 10$ ). A more precise age determination is not possible, either because discoasters occur sporadically, or because they are heavily overgrown and their identification uncertain.

On the basis of the presence of numerous specimens of the variety of Coccolithus pelagicus, which is described by Bukry (this volume) as Coccolithus miopelagicus, Core 6 probably represents the middle Miocene. The species seems to be typical for the lower part of the middle Miocene (approximately nannoplankton Zone NN 6/NN 7). The middle Miocene section is underlain by lower Eocene sediments, and the hiatus represents an interval of about 36 m.y.

The Discoaster lodoensis Zone (NP 13) occurs from Core 7 to Core 9 on the basis of the absence of Discoaster sublodoensis and Marthasterites tribrachiatus. Discoasters are scarce in this sequence. Discoaster lodoensis occurs sporadically, and is frequent only in Sample 7-1, 61-62 cm. A few specimens of Imperiaster obscurus were observed in almost all samples. This species is most abundant in Sample 8-1, 63-65 cm. Imperiaster obscurus was described, until now, only from the Discoaster binodosus Zone (NP 11) and Marthasterites tribrachiatus Zone (NN 12). The sediments are rich in siliceous microfossils; nannofossils are abundant 
in several layers. They are partially strongly etched, and are absent in the volcanic ash layer of Sample $8, \mathrm{CC}$. The amount of siliceous microfossils decreases below Core 8 , Section 2. They are absent from Sample 11, CC downwards. The Marthasterites tribrachiatus Zone (NP 12) occurs from Core 10 to Core 16, Section 1. Marthasterites tribrachiatus is rare and Discoaster lodoensis is present only sporadically. Nannofossils are abundant from Core 11 downwards and are poorly preserved.

The sequence from Core 16, Section 2 to at least Core 21 (286.0-341.5 m) belongs to the Marthasterites contortus/Discoaster binodosus Zone (NP 10/NP 11) of the lower Eocene. The determination of the boundary between these two zones is difficult, and probably can be placed between Core 17 and Core 18. Only one specimen of Marthasterites bramlettei occurs in Sample 21 4, 47-48 cm. Nannofossils are scarce from Core 17 downwards, which is caused by the high amount of terrigenous material. Sediments of Core 21 to Core 26 (332.0-389.0 m) are barren of nannofossils.

\section{Palynormorphs and Dinoflagellates ${ }^{3}$}

Cores 23 to 21 (Zone Ia) are upper Paleocene to lower Eocene and compare closely with Cores 41 to 35 of Site 403 , although they are somewhat richer in dinocysts. Apectodinium spp. dominate the marine element of an essentially littoral sediment. Core 23 yields the upper Paleocene indicator $A$. aff. augustum.

Core 20 to Section 16-2 yield Zone Ib (Costa and Downie, in press) (lower Eocene). In Core 20, Wetzeliella meckelfeldensis occurs with Apectodinium sumissum, indicating equivalence with the lowermost Ypresian. Sections 17-3 and 17-5 closely resemble Core 29 of Site 403 , and mark the initial flooding of the area. A dominance of Micrhystridium and Spiniferites suggests inshore sedimentation.

Section 16-1 and Core 14 (Zone II) are also lower Eocene. The dinocysts indicate a fluctuating, more or less shallow, marine environment, and an equivalence with the upper London Clay. No equivalent has been recognized at Site 403.

Cores 12 to 10 yield Zone III (lower Eocene), equivalent to the lower part of the Bracklesham Beds of England. Dinocysts become abundant, indicating increasing water depth to offshore conditions. Hemicystodinium zoharyi is dominant in Section 12-1, and probably indicates warm water. Thalassiphora and Areoligera become dominant in Core 10 .

Core 8 is a deep water mid Eocene sediment, poor in palynomorphs. Leptodinium dominates a practically monospecific assemblage in Section 8-2; the few dinocysts recovered from Section 8-1 appear to indicate equivalence with Zone IV.

Core 7 is barren. Core 6 is poor in palynomorphs and yields only a few Eocene dinocysts, possibly reworked.

Cores 4 and 2 are also poor in dinocysts; the few observed indicate Miocene-Pliocene (Zone VIII).

With the exception of the Eocene dinocysts occurring in Core 6 , reworking was not observed in this hole.

\footnotetext{
${ }^{3}$ See footnote 2 .
}

Section 8-2 yields highly carbonized material (Thermal Alteration Index $=3-5$ ) which could be attributed to diagenetic changes associated with chert formation. In the remainder of the samples from this site, the thermal alteration is low (Thermal Alteration Index $=1-2$ ).

\section{Ostracodes}

Only Poseidonamicus occurs in the Pliocene-Pleistocene section. The upper Miocene sediments contain: Henryhowella asperrima, Cytherella consueta, Krithe, and Poseidon-amicus. The Eocene is represented by $\mathrm{Her}$ manites? (reticulate form), Paracypris, Parakrithe, and Loxoconcha. Only Hermanites? (tuberculate form) occurs in the Paleocene section.

\section{PHYSICAL PROPERTIES}

\section{Site $\mathbf{4 0 3}$}

Determinations of physical properties (in addition to downhole logs of gamma ray and sound speed) involved 50 samples from 489 meters of hole for an average of one sample per 9.7 meters or one sample per 7.9 meters for the top 394 meters of hole. The introduction to this volume includes discussion of purpose and procedures for these measurements and related calculations.

The ranges of determinations on cores include: coring time $(.2-7.6 \mathrm{~min} / \mathrm{m})$, sound speed $(1.6-4.1 \mathrm{~km} / \mathrm{s})$, wet bulk density $\left(1.17-2.48 \mathrm{~g} / \mathrm{cm}^{3}\right)$, sound impedance (2.16-10.19 units), porosity $(18-69 \%)$, and water content $(8-43 \%)$. The data presentation consists of numerical tables in this site report (Tables 5 and 6 ) and depth plots on the superlogs in the pocket of this volume.

Compaction and per cent $\mathrm{CaCO}_{3}$ notably influence the physical properties in the top 260 meters of the hole, including a possible seismic reflector at about 65 meters. Between the ocean bottom and sub-bottom depth of 50 meters the increase in wet bulk density along with decreases in porosity and water content reasonably relate to the increase in per cent $\mathrm{CaCO}_{3}$ (from 60 to $90 \%$ ). However, between depths of 50 and 70 meters, the increases in porosity and water content seem inconsistent with the continued increase in wet bulk density. The trend of increasing sound speed shown by the downhole log between depth 115 and 200 meters (along with continued increase of wet bulk density and decreases of porosity and water content) indicates greater elasticity, the cause of which (compaction or cementation?) remains unexplained. Between depths of 200 and 260 meters, the decrease in wet bulk density with increases of porosity and water content seems consistent with the decrease in per cent $\mathrm{CaCO}_{3}$, which also would explain the decrease in sound speed (between depths of 200 and $240 \mathrm{~m}$ ), but the abrupt increase in sound speed (between 240 and $260 \mathrm{~m}$ ) requires further explanation.

Between sub-bottom depths of 260 and 395 meters composition (mudstone versus volcanics), along with silicification related to the volcanics, apparently control the physical properties including probable seismic reflectors at 265 and between 350 and 380 meters. Silicification related to volcanics in both the 260 to 270 and 350 to 380 intervals has caused abrupt increases in sound speed, wet bulk 
TABLE 5

Physical Property Summary, Site 403

\begin{tabular}{|c|c|c|c|c|c|c|c|c|c|c|c|c|c|c|c|c|c|c|c|}
\hline \multirow[b]{4}{*}{$\begin{array}{c}\text { Sample } \\
\text { (Interval in cm) }\end{array}$} & \multirow[b]{4}{*}{$\begin{array}{c}\text { Depth } \\
\text { Sub- } \\
\text { Bottom } \\
(\mathrm{m})\end{array}$} & \multicolumn{8}{|c|}{$\begin{array}{l}\text { Sound Velocity }(\mathrm{km} / \mathrm{s}) \\
\text { (Hamilton Frame) }\end{array}$} & \multicolumn{3}{|c|}{$\begin{array}{c}\text { Bulk Density } \\
\left(\mathrm{g} / \mathrm{cm}^{3}\right)\end{array}$} & \multicolumn{2}{|c|}{$\begin{array}{c}\text { Sound } \\
\text { Impedance }\end{array}$} & \multicolumn{2}{|c|}{$\begin{array}{l}\text { Porosity } \\
(\%)\end{array}$} & \multirow{4}{*}{$\begin{array}{c}\mathrm{H}_{2} \mathrm{O} \\
(\%) \\
\text { (by } \\
\text { wt.) }\end{array}$} & \multirow[b]{4}{*}{$\begin{array}{l}\mathrm{CO}_{3} \\
(\%) \\
\end{array}$} & \multirow[b]{4}{*}{ Lithology } \\
\hline & & \multicolumn{2}{|c|}{ Slabs } & \multicolumn{3}{|c|}{ Plugs } & \multicolumn{2}{|c|}{ Anisotropy } & & & & & g & & & & & & \\
\hline & & & & Rot & & Flat & $\|-1$ & $\|-1$ & & & & & $\left(\mathrm{~cm}^{2} / \mathrm{s}\right.$ & $10^{5}$ & & & & & \\
\hline & & $\begin{array}{c}\| \\
\text { to } \\
\text { Beds }\end{array}$ & $\begin{array}{c}1 \\
\text { to } \\
\text { Beds }\end{array}$ & $\begin{array}{c}11 \\
\text { to } \\
\text { Beds }\end{array}$ & $\begin{array}{c}1 \\
\text { to } \\
\text { Beds }\end{array}$ & $\begin{array}{c}\| 1 \\
\text { to } \\
\text { Beds }\end{array}$ & $\begin{array}{c}+ \\
\text { or } \\
- \\
\end{array}$ & $\begin{array}{l}1 \\
(\%)\end{array}$ & $\mathrm{C}^{\circ}$ & 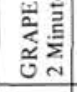 & 总官 & 弟官 & 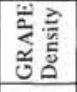 & 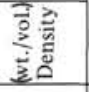 & |ٕ: & $\begin{array}{l}\text { Wt. } \\
\mathrm{H}_{2} \mathrm{O} \\
\text { Vol. }\end{array}$ & & & \\
\hline $1-2,126-131$ & 2.79 & 1.67 & & & & & & & 14 & 1.59 & 1.31 & & 2.66 & 2.19 & & 48.46 & 37.00 & & $\tan$ ooze \\
\hline $1-4,62-70$ & 5.16 & 1.69 & & & & & & & 14 & 1.67 & 1.39 & & 2.82 & 2.35 & & 47.94 & 34.46 & & $\tan$ ooze \\
\hline $2-2,71-79$ & 6.75 & 1.65 & & & & & & & 14 & 1.58 & & & 2.61 & & & & & & $\tan$ ooze \\
\hline $2-5,61-68$ & 11.48 & 1.60 & & & & & & & 14 & & 1.35 & & & 2.16 & & 44.86 & 33.19 & & white ooze \\
\hline $2-5,142-150$ & 12.29 & & & & & & & & & & 1.36 & & & & & 45.14 & 33.08 & & white ooze \\
\hline $3-2,116-123$ & 17.45 & 1.63 & & & & & & & 15 & 1.58 & 1.37 & & 2.58 & 2.23 & & 45.94 & 33.46 & & brown ooze \\
\hline $5-1,128-130$ & 34.29 & & & & & & & & & & 1.17 & & & & & 39.69 & 34.01 & & white ooze \\
\hline $\begin{array}{l}5-2,126-130 \\
7-1,60-64\end{array}$ & $\begin{array}{l}35.78 \\
52.62\end{array}$ & $\begin{array}{l}1.70 \\
1.71\end{array}$ & & & & & & & 13 & 1.62 & & & 2.75 & & & & & & white ooze \\
\hline $\begin{array}{l}7-1,60-64 \\
7-1,140-150\end{array}$ & 53.45 & & & & & & & & 14 & 1.71 & $\begin{array}{l}1.41 \\
1.47\end{array}$ & & 2.92 & 2.41 & & $\begin{array}{l}40.86 \\
38.57\end{array}$ & $\begin{array}{l}29.04 \\
26.28\end{array}$ & & $\begin{array}{l}\text { white ooze } \\
\text { white ooze }\end{array}$ \\
\hline $\begin{array}{l}7-1,140-150 \\
8-2,77-86\end{array}$ & 63.85 & 1.70 & & & & & & & 14 & 1.80 & 1.71 & & 3.06 & 2.91 & & 59.36 & 34.77 & & white ooze \\
\hline $8-5,80-85$ & 68.33 & 1.67 & & & & & & & 14 & & 1.75 & & & 2.92 & & 58.06 & 33.26 & & white ooze \\
\hline $8-6,80-82$ & 69.81 & & & & & & & & & 1.82 & & & & & & & & & white ooze \\
\hline $9-5,99-108$ & 77.94 & 1.73 & & & & & & & 13 & 1.66 & 1.49 & & 2.87 & 2.58 & & 62.29 & 41.71 & & white ooze \\
\hline $11-2,73-77$ & 92.25 & 1.69 & & & & & & & 17 & 1.83 & 1.71 & & 3.09 & 2.89 & & 59.33 & 34.66 & & white ooze \\
\hline $12-6,144-150$ & 108.47 & & & & & & & & & & 1.75 & & & & & 51.86 & 29.69 & & white ooze \\
\hline $12-7,34-39$ & 108.87 & 1.70 & & & & & & & 22 & & 1.67 & & & 2.84 & & 55.13 & 32.92 & & white ooze \\
\hline $13-1,35-40$ & 109.38 & 1.65 & & & & & & & 18 & 1.78 & 1.63 & & 2.94 & 2.69 & & 55.57 & 34.05 & & white ooze \\
\hline $14-2,48-52$ & 120.50 & & & & & & & & 17 & & 1.66 & & & & & 63.82 & 38.36 & & white ooze \\
\hline $18-2,117-123$ & 159.20 & & & & & & & & & & 1.77 & & & & & 51.46 & 32.44 & & white ooze \\
\hline $\begin{array}{l}21-2,56 * 59 \\
21-3,93-96\end{array}$ & $\begin{array}{l}186.58 \\
188.95\end{array}$ & & & & & & & & & $\begin{array}{l}1.83 \\
1.89\end{array}$ & 1.70 & & & & & 56.29 & 33.04 & & white ooze \\
\hline & $\begin{array}{l}188.95 \\
197.00\end{array}$ & 1.60 & & & & & & & & $\begin{array}{l}1.89 \\
1.91\end{array}$ & 1.74 & & 3.06 & 2.80 & & & & & white ooze \\
\hline $\begin{array}{l}22-2,97-103 \\
22-5,94-99\end{array}$ & 201.47 & 1.64 & & & & & & & $\begin{array}{l}17 \\
17\end{array}$ & $\begin{array}{l}1.91 \\
1.74\end{array}$ & 1.67 & & $\begin{array}{l}3.06 \\
2.78\end{array}$ & 2.74 & & $\begin{array}{l}59.03 \\
54.09\end{array}$ & $\begin{array}{l}33.95 \\
32.41\end{array}$ & & white ooze \\
\hline $\begin{array}{l}22-5,94-99 \\
22-6,32-35\end{array}$ & 202.34 & 1.65 & & & & & & & 20 & 1.14 & & & 2.10 & & & 54.09 & 32.41 & & $\begin{array}{l}\text { white ooze } \\
\text { white ooze }\end{array}$ \\
\hline $26-2,140-150$ & 235.45 & 1.55 & & & & & & & & & & & & & & 58.49 & 37.77 & & $\begin{array}{l}\text { white ooze } \\
\text { white ooze }\end{array}$ \\
\hline $27-1,10-13$ & 242.12 & & & 1.68 & 1.67 & 1.68 & +0.01 & +0.01 & 19 & 1.62 & & & 2.72 & & & & & & tan chalk \\
\hline $28-1,24-28$ & 251.76 & 1.77 & & & & & & & 19 & 1.82 & & 1.77 & 3.22 & 3.13 & & 55.42 & 31.32 & & green ash \\
\hline $29-1,32-36$ & 261.34 & 1.83 & 1.80 & 1.82 & & 1.83 & & & 19 & 1.62 & & 1.58 & 2.96 & 2.89 & & 68.51 & 43.33 & & black mudstone \\
\hline $29-2,130-133$ & 263.82 & 1.88 & 1.83 & 1.88 & 1.87 & 1.91 & +0.01 & +0.01 & 18 & 1.66 & & 1.63 & 3.12 & 3.06 & & 65.72 & 40.42 & & black mudstone \\
\hline $29-4,74-77$ & 266.26 & 2.24 & 2.24 & 2.22 & 2.19 & 2.21 & +0.03 & +0.01 & 19 & 1.90 & & 1.81 & 4.22 & 4.02 & & 56.64 & 31.35 & & tuff \\
\hline $30-1,25-27$ & 270.76 & 2.36 & 2.36 & 2.38 & 2.40 & 2.41 & +0.02 & +0.01 & 21 & 1.93 & & 1.83 & 4.59 & 4.36 & & 53.85 & 29.43 & & black tuff \\
\hline $34-2,48-55$ & 310.52 & 1.99 & 1.95 & 2.03 & 1.93 & 2.00 & +0.10 & +0.05 & 21 & 1.76 & & 1.75 & 3.54 & 3.52 & & 57.68 & 32.99 & & black tuff \\
\hline $34-4,22-27$ & 313.25 & 1.97 & 1.92 & 1.94 & 1.93 & 1.98 & +0.01 & +0.01 & 21 & 1.74 & & 1.76 & 3.41 & 3.45 & & 57.57 & 32.79 & & black tuff \\
\hline $34-4,140-150$ & 314.45 & & & & & & & & & & & 1.84 & & & & 51.60 & 28.08 & & black tuff \\
\hline $35-1,31-34$ & 318.33 & 1.98 & 1.93 & 1.96 & 1.95 & 1.99 & +0.01 & +0.06 & 20 & 1.73 & & 1.70 & 3.43 & 3.37 & & 60.03 & 35.21 & & black mudstone \\
\hline $35-4,66-70$ & 323.18 & 2.07 & 2.02 & 2.05 & 2.03 & 2.03 & +0.02 & +0.01 & 20 & 2.03 & & 1.68 & 4.16 & 3.44 & & 63.02 & 37.61 & & black mudstone \\
\hline $36-1,69-73$ & 328.21 & 1.84 & & 1.85 & 1.81 & 1.85 & +0.04 & +0.02 & 21 & 1.93 & & 1.71 & 3.57 & 3.16 & & 59.98 & 35.06 & & black mudstone \\
\hline $37-2,62-66$ & 339.14 & 2.06 & 1.96 & 2.04 & 1.97 & 1.98 & +0.07 & +0.04 & 20 & 1.81 & & 1.75 & 3.69 & 3.57 & & 57.61 & 32.89 & & black mudstone \\
\hline $37-5,87-91$ & 343.89 & 1.95 & 1.86 & & 1.85 & 1.94 & & & 20 & 1.71 & & 1.66 & 3.33 & 3.24 & & 62.35 & 37.48 & & black mudstone \\
\hline $38-3,62-65$ & 350.14 & 1.78 & 1.72 & 1.80 & 1.73 & 1.80 & +0.07 & +0.04 & 19 & 1.77 & & 1.73 & 3.19 & 3.11 & & 58.24 & 33.65 & & black mudstone \\
\hline $38-4,65-69$ & 351.67 & & 4.10 & 4.11 & 4.11 & 4.13 & 0.0 & 00.0 & 19 & 2.48 & & 2.43 & 10.19 & 9.99 & & 18.35 & 7.56 & & green-linestone \\
\hline $39-2,137-140$ & 358.89 & & 1.89 & & 1.88 & & & & 19 & 1.62 & & 1.65 & 3.06 & 3.12 & & 65.24 & 39.65 & & tuffa mudstone \\
\hline $39-3,55-59$ & 359.57 & 2.27 & 2.23 & 2.22 & 2.27 & 2.27 & -0.05 & -0.02 & 19 & 2.02 & & 1.91 & 4.59 & 4.34 & & 51.96 & 27.18 & & tuffa mudstone \\
\hline $40-1,68-71$ & 366.20 & 2.03 & 1.97 & 2.01 & 1.96 & 2.05 & +0.05 & +0.03 & 19 & 1.71 & & 1.68 & 3.47 & 3.41 & & 64.07 & 38.15 & & muddy tuff \\
\hline $41-2,76-79$ & 377.28 & & 2.53 & 2.52 & 2.56 & 2.51 & ++.01 & $<0.01$ & 19 & 1.91 & & 1.89 & 4.81 & 4.76 & & 49.79 & 26.29 & & muddy tuff \\
\hline $41-4,96-102$ & 380.49 & 2.52 & 2.57 & 2.54 & 2.55 & 2.51 & -0.01 & $<0.01$ & 19 & 1.96 & & 1.91 & 4.94 & 4.81 & & 48.40 & 25.32 & & muddy tuff \\
\hline $42-1,4-8$ & 384.56 & 2.47 & 2.44 & 2.46 & 2.44 & 2.49 & +0.02 & +0.01 & 19 & 1.86 & & 1.85 & 4.55 & 4.55 & & 50.41 & 27.26 & & muddy tuff \\
\hline $42-3,2-6$ & 387.54 & 2.39 & 2.35 & 2.35 & 2.35 & 2.38 & 0.0 & 0.0 & 19 & 1.90 & & 1,83 & 4.50 & 4.34 & & 54.16 & 29.65 & & muddy tuff \\
\hline $43-1,103-107$ & 395.05 & 2.41 & 2.30 & 2.41 & 2.31 & 2.40 & +0.10 & +0.04 & 19 & 1.93 & & 1.87 & 4.65 & 4.51 & & 50.00 & 26.77 & & muddy tuff \\
\hline 44 & & & & & & & & & & & & & & & & & & & \\
\hline 56 & $\begin{array}{l}\text { nts } \\
489.00\end{array}$ & & & & & & & & & & & & & & & & & & \\
\hline $\mathrm{TD}=$ & & & & & & & & & & & & & & & & & & & \\
\hline
\end{tabular}

density, and sound impedance with abrupt decreases in porosity and water content.

Fluctuations in gamma ray reasonably result from complex associations of radioactive versus non-radioactive volcanics, absorption of uranium ions on organic material, and radioactive minerals in arkosic sandstone. The increase in gamma ray between depths of 240 and 275 meters parallels the influx of volcanics, but the volcanics in the 350 to 385 meter interval show up as a gamma-ray low. The arkosic sandstones between depths 418 and 460 meters indicate high radioactivity.

\section{Site 404}

Determination of physical properties involved 48 samples from 389 meters of hole for an average of one sample per 8.1 meters or one sample per 5 meters for the bottom 219 meters of hole. Weather prevented obtaining any downhole logs.

The ranges of determinations on cores include: coring time $(0.2-3.8 \mathrm{~min} / \mathrm{m})$, sound speed $(1.7-3.88 \mathrm{~km} / \mathrm{s})$, wet bulk density $\left(1.37-2.35 \mathrm{~g} / \mathrm{cm}^{3}\right)$, sound impedance (2.14-9.12 units), porosity (22-69\%), and water content $(9-49 \%)$.

The wide fluctuations in physical properties generally relate to changes in composition including perhaps three seismic reflectors at sub-bottom depths of 270,315 , and 360 meters indicated by abrupt impedance increases. The increase in per cent $\mathrm{CaCO}_{3}$ between the ocean bottom and sub-bottom depth of 180 meters reasonably causes the increase in wet bulk density without increase in sound speed. The high percentage of $\mathrm{SiO}_{2}$ between depths of 200 and 240 meters reasonably causes the low in wet bulk 
TABLE 6

Physical Property Summary, Site 404

\begin{tabular}{|c|c|c|c|c|c|c|c|c|c|c|c|c|c|c|c|c|c|}
\hline \multirow[b]{3}{*}{$\begin{array}{c}\text { Sample } \\
\text { (Interval in } \mathrm{cm} \text { ) }\end{array}$} & \multirow[b]{3}{*}{$\begin{array}{l}\text { Depth } \\
\text { Sub- } \\
\text { Bottom } \\
\text { (m) }\end{array}$} & \multicolumn{6}{|c|}{$\begin{array}{l}\text { Sound Speed }(\mathrm{km} / \mathrm{s}) \\
\text { (Hamilton Frame) }\end{array}$} & \multicolumn{3}{|c|}{$\begin{array}{l}\text { Bulk Density } \\
\left(\mathrm{g} / \mathrm{cm}^{3}\right)\end{array}$} & \multicolumn{2}{|c|}{$\begin{array}{l}\text { Sound } \\
\text { Impedance }\end{array}$} & \multicolumn{2}{|c|}{$\begin{array}{l}\text { Porosity } \\
(\%)\end{array}$} & \multirow[b]{3}{*}{$\begin{array}{l}\mathrm{H}_{2} \mathrm{O} \\
(\%)\end{array}$} & \multirow{3}{*}{\multicolumn{2}{|c|}{ Lithology }} \\
\hline & & \multirow[b]{2}{*}{$\mathrm{C}^{\circ}$} & \multicolumn{3}{|c|}{ Measurements } & \multicolumn{2}{|c|}{ Anisotropy } & \multirow[b]{2}{*}{ 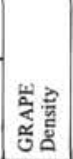 } & \multirow[b]{2}{*}{ 总高 } & \multirow[b]{2}{*}{ है } & {$\left[\frac{\mathrm{g}}{\left(\mathrm{cm}^{2} /\right.}\right.$} & c) $] 10^{5}$ & & & & & \\
\hline & & & 总 & $\begin{array}{c}\| \\
\text { to } \\
\text { Beds } \\
\end{array}$ & $\begin{array}{c}1 \\
\text { to } \\
\text { Beds }\end{array}$ & $\begin{array}{c}\|-1 \\
+ \\
-\end{array}$ & $\frac{1}{\%}$ & & & & 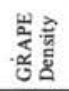 & 总言 & 裚 & $\begin{array}{l}0 \\
i^{2} \\
5\end{array}$ & & & \\
\hline $2-4,140-150$ & 27.45 & & & & & & & & 1.57 & & & & & 65.63 & 41.76 & & \\
\hline $2-6,106-111$ & 30.09 & 18 & split & 1.72 & & & & $c_{1.60}$ & 1.49 & & 2.75 & 2.56 & & 65.28 & 43.88 & & white ooze \\
\hline $2-6,123-127$ & 30.25 & 18 & split & 1.69 & & & & $c_{1.64}^{1.00}$ & 1.67 & & 2.77 & 2.82 & & $\begin{array}{l}03.20 \\
61.49\end{array}$ & 32.92 & & brown ooze \\
\hline $3-1,64-70$ & 104.67 & 19 & split & 1.70 & & & & & 1.71 & & & 2.91 & & 58.53 & 34.32 & & white ooze \\
\hline $4-1,140-150$ & 171.95 & & & & & & & & 1.57 & & & & & 65.29 & 41.47 & & white ooze \\
\hline $5-1,90-95$ & 180.93 & 19 & split & 1.73 & & & & 1.72 & 1.64 & & 2.98 & 2.84 & & 56.63 & 34.54 & & white ooze \\
\hline $5-2,136-141$ & 182.89 & 19 & split & 1.81 & & & & 1.78 & & 1.75 & 3.22 & 3.17 & & 55.15 & 31.51 & & white chalk \\
\hline $6-2,10-14$ & 191.12 & 21 & split & 1.70 & & & & & 1.66 & & & 2.82 & & 56.33 & 34.03 & & white ooze \\
\hline $7-2,116-120$ & 201.68 & 21 & split & 1.77 & & & & & & 1.42 & & 2.51 & & 67.89 & 47.70 & & sility chalk \\
\hline $7-2,140-150$ & 201.95 & & & & & & & & 1.37 & & & & & 61.72 & 45.10 & & \\
\hline $\begin{array}{l}8-1,103-105 \\
9\end{array}$ & 209.54 & & & & & & & & & 1.45 & & & & 67.83 & 46.67 & & \\
\hline $10-1,80-83$ & 228.31 & 21 & slab & 1.79 & & & & 1.51 & & 1.46 & 2.70 & 2.61 & & 67.30 & 46.12 & & chalk mottled \\
\hline $11-1,52-56$ & 237.54 & 21 & slab & 1.41 & & & & 1.53 & & 1.52 & 2.16 & 2.14 & & 68.91 & 45.45 & & chalk mottled \\
\hline $12-1,60-66$ & 247.13 & 21 & plug & 3.74 & 3.79 & -0.05 & -0.01 & 1.99 & & 2.08 & 7.44 & 7.78 & & 13.53 & 6.49 & & chert glau. \\
\hline $14-1,38-41$ & 265.90 & 21 & plug & 2.08 & 2.04 & +0.04 & +0.02 & 1.49 & & 1.46 & 3.10 & 3.04 & & 69.10 & 47.21 & & tuff limy \\
\hline $15-1,32-44$ & 275.38 & 21 & plug & 2.82 & 2.49 & +0.33 & +0.13 & 1.86 & & 1.92 & 5.25 & 5.40 & & 30.85 & 16.03 & & mudstone \\
\hline $16-1,37-42$ & 284.90 & 21 & plug & 2.86 & 2.68 & +0.18 & +0.07 & 1.93 & & 1.93 & 5.52 & 5.52 & & 32.44 & 16.83 & & mudstone glau. \\
\hline $16-1,98-101$ & 285.50 & 21 & plug & 2.61 & 2.49 & +0.12 & +0.05 & 1.71 & & 1.78 & 4.46 & 4.65 & & 43.82 & 24.64 & & mudstone glau. \\
\hline $16-2,25-28$ & 286.27 & 21 & plug & 1.87 & 1.80 & +0.07 & +0.04 & 1.73 & & 1.71 & 3.24 & 3.20 & & 53.96 & 31.49 & & limestone marly \\
\hline $16-2,96-99$ & 286.98 & 21 & plug & 2.63 & 2.57 & +0.06 & +0.02 & 1.91 & & 1.93 & 5.02 & 5.08 & & 37.37 & 19.39 & & mudstone, glau. \\
\hline $17-1,113-118$ & 295.16 & 19 & plug & 1.77 & 1.78 & -0.08 & -0.01 & 1.57 & & 1.47 & 2.78 & 2.60 & & 73.51 & 49.97 & & mudstone, glau. \\
\hline $17-3,86-89$ & 297.88 & 19 & plug & 1.85 & 1.79 & +0.06 & +0.03 & 1.62 & & 1.67 & 3.00 & 3.09 & & 64.06 & 38.37 & & mudstone, glau. limy \\
\hline $17-3,140-150$ & 298.45 & 19 & & & & & & & & 1.63 & & & & 66.04 & 40.48 & & mudstone, tuffa \\
\hline $17-4,90-94$ & 299.42 & 19 & plug & 1.89 & 1.89 & 0.0 & +0.0 & 1.73 & & 1.71 & 3.27 & 3.23 & & 61.36 & 35.83 & & mudstone, tuffa \\
\hline $17-5,22-26$ & 300.24 & 19 & plug & 2.04 & 2.02 & +0.02 & +0.01 & 1.77 & & 1.67 & 3.61 & 3.41 & & 63.52 & 38.07 & & mudstone, tuffa \\
\hline $17-6,10-13$ & 301.62 & 19 & plug & 1.87 & 1.84 & +0.03 & +0.02 & 1.66 & & & 3.10 & & & & & & mudstone, tuffa \\
\hline $18-1,11-14$ & 303.63 & 18 & plug & 1.89 & 1.86 & +0.03 & +0.02 & 1.65 & & 1.62 & 3.12 & 3.06 & & 65.13 & 40.22 & & mudstone tuffa \\
\hline $18-1,122-125$ & 304.74 & 18 & plug & 1.87 & 1.86 & +0.01 & +0.01 & 1.71 & & 1.69 & 3.20 & 3.16 & & 62.83 & 37.19 & & mudstone tuffa \\
\hline $18-2,14-16$ & 305.15 & 18 & plug & 1.76 & 1.73 & +0.03 & +0.02 & 1.65 & & 1.62 & 2.90 & 2.85 & & 65.19 & 40.23 & & mudstone tuffa \\
\hline $18-2,44-46$ & 305.45 & 18 & plug & 2.50 & 2.49 & +0.01 & +0.00 & 2.35 & & & 5.88 & & & & & & mudstone tuffa \\
\hline $18-2,90-92$ & 305.91 & 18 & plug & 2.06 & 2.08 & -0.02 & -0.01 & 1.84 & & & 3.79 & & & & & & mudstone tuffa \\
\hline $20-1,112-114$ & 323.63 & 18 & plug & 3.88 & 3.83 & +0.05 & +0.01 & 2.26 & & 2.35 & 8.77 & 9.12 & & 21.84 & 9.30 & & sandstone aruosic \\
\hline $21-1,06-09$ & 322.58 & 19 & plug & 2.72 & 2.76 & -0.04 & -0.01 & 2.05 & & 2.01 & 5.58 & 5.71 & & 40.28 & 20.00 & & mudstone \\
\hline $21-4,43-49$ & 336.96 & 19 & plug & 1.90 & 1.86 & +0.04 & +0.02 & 1.62 & & 1.65 & 3.08 & 3.14 & & 61.75 & 37.53 & & mudstone tuffaeous \\
\hline $22-1,04-08$ & 341.56 & 20 & plug & 2.12 & 2.06 & +0.06 & +0.03 & 1.80 & & 1.74 & 3.82 & 3.69 & & 58.36 & 33.58 & & mudstone tuffaeous \\
\hline $22-2,146-150$ & 344.48 & 20 & plug & 1.78 & 1.74 & +0.04 & +0.02 & 1.69 & & 1.66 & 3.01 & 2.95 & & 59.84 & 36.14 & & mudstone tuffaeous \\
\hline $22-3,126-133$ & 345.80 & 20 & plug & 1.99 & 1.93 & +0.06 & +0.03 & 1.64 & & 1.68 & 3.26 & 3.34 & & 62.79 & 37.28 & & mudstone \\
\hline $22-4,133-138$ & 347.36 & 20 & plug & 1.73 & 1.70 & +0.03 & +0.02 & 1.73 & & 1.72 & 2.99 & 2.98 & & 51.13 & 33.14 & & mudstone \\
\hline $22-4,140-150$ & 347.45 & 20 & & & & & & & & 1.60 & & & & 66.82 & 41.65 & & mudsonte \\
\hline $22-5,105-108$ & 348.57 & 20 & plug & 1.91 & 1.86 & +0.05 & +0.03 & 1.70 & & 1.68 & 3.25 & 3.21 & & 61.59 & 36.69 & & mudstone \\
\hline $23-2,24-27$ & 352.76 & 20 & plug & 1.85 & 1.79 & +0.06 & +0.03 & 1.68 & & 1.67 & 3.11 & 3.09 & & 62.32 & 37.31 & & mudstone \\
\hline $23-3,144-149$ & 355.47 & 20 & plug & 2.13 & 2.13 & 0.0 & 0.0 & 1.85 & & 1.76 & 3.94 & 3.75 & & 56.92 & 32.28 & & mudstone \\
\hline $23-4,135-140$ & 356.88 & 20 & plug & 1.89 & 1.85 & +0.04 & +0.02 & 1.67 & & 1.71 & 3.16 & 3.23 & & 59.57 & 34.87 & & mudstone \\
\hline $23-5,142-147$ & 358.45 & 20 & plug & 1.86 & 1.81 & +0.05 & +0.03 & 1.67 & & 1.70 & 3.11 & 3.16 & & 59.36 & 34.91 & & mudstone \\
\hline $23-6,52-54$ & 359.03 & 20 & plug & 2.46 & 2.38 & +0.08 & +0.03 & 2.03 & & 1.96 & 4.99 & 4.82 & & 48.21 & 24.63 & & mudstone \\
\hline $24-1,11-15$ & 360.63 & 20 & plug & 2.45 & 2.49 & -.04 & -0.02 & 2.03 & & 1.96 & 4.97 & 4.80 & & 43.42 & 22.11 & & sandstone \\
\hline $25-1,05-10$ & 370.75 & 20 & plug & 1.98 & 1.98 & 0 & 0 & 2.26 & & 2.27 & 4.47 & 4.49 & & 28.98 & 12.75 & & sandstone \\
\hline $26-1,10-18$ & 376.64 & 20 & plug & 2.58 & 2.59 & -0.01 & 0 & 2.14 & & 2.12 & 5.52 & 5.49 & & 36.86 & 17.38 & & conglomerate \\
\hline Total depth & 389.00 & & & & & & & & & & & & & & & & \\
\hline
\end{tabular}

density along with increases in porosity and water content where the sound speed shows little change. The three impedance highs (probably seismic reflectors) apparently indicate calcareous porcellanite $(270 \mathrm{~m})$, limestone $(315$ $\mathrm{m})$, and sandstone $(360 \mathrm{~m})$; the sound speeds and wet bulk densities increase where the porosities and water contents decrease.

Prominent impedance lows at sub-bottom depths of 285 to 305 and 335 to 360 meters relate to glauconitic mudstones and carbonaceous mudstones, respectively. In both intervals the porosities and water contents increase abruptly causing sharp decreases in the wet bulk densities and sound speeds.

\section{DOWNHOLE LOGGING, SITE 403}

\section{Mann}

Borehole Compensated Sonic/Gamma Ray/Caliper (BHCS/GR/CAL) logs were run at Site 403; other logs were not run because of deteriorating weather conditions and pipe was pulled immediately after the sonic run. All depths quoted in this section refer either to depths marked on the logging runs or to their equivalent sub-sea bottom depths.

In the discussion of the lithological units and sub-units, the lithological data and depths have been taken from the site summaries and Initial Core Description. Figure 11 is a composite of the logging curves plotted against depth matched against cores. A generalized stratigraphic summary and the main logging breaks are also shown in Figure 11.

Figure 12 shows the good correlation between drilling and logging results. Where discrepancies in depth appear to be artificial, a double arrow marking has been used. Other logging markers that may have lithological and/or sedimentological significance have been additionally marked in the depth column.

The physical properties data generally match the logging results except in zones of poor recovery between 120 and 300 meters and from 400 meters to total depth. 


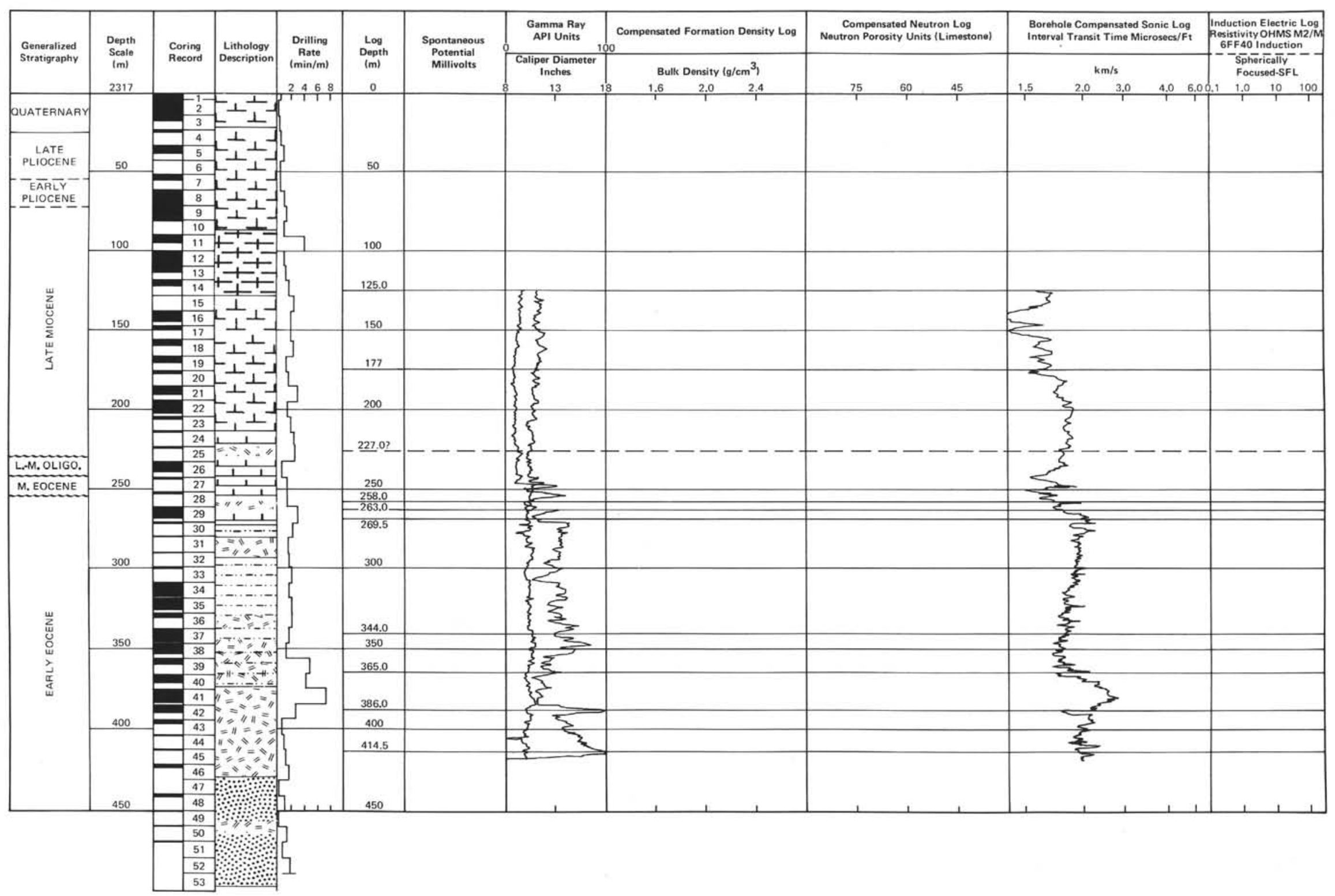

Figure 11. Downhole logs and generalized stratigraphy Site 403 with principal logging breaks. 
SITE 403

percentage $\underset{\mathrm{CaCO}_{3}}{\mathrm{Clay}}+$

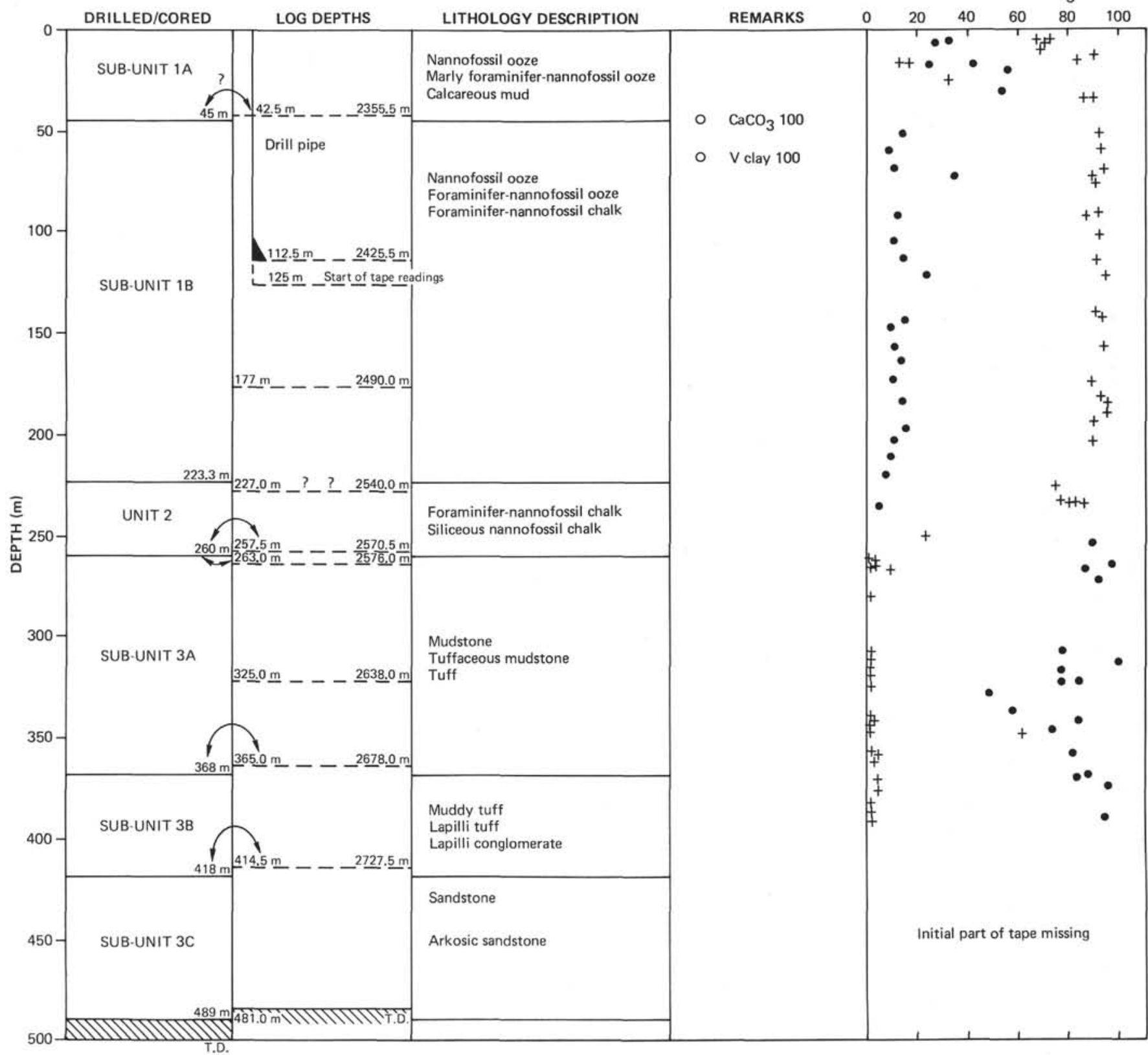

Figure 12. Correlation of lithologic units and logging breaks, Sites 403 and 404.

\section{Interpretation}

\section{Unit 1}

Sub-unit 1A (2313.0-2358.0 m [0-45.0 m]): The only log recorded over this interval was the gamma ray which was measured through the drill pipe. The log shows a sea-bed depth of 2313 meters $(0 \mathrm{~m})$. The lithology consists predominantly of marly foraminifer/nannofossil ooze, nannofossil ooze, and calcareous mud.

Sub-unit 1B (2358.0-2536.3 m [45.0-223.3 m]) Figure 12: The marked fall in the gamma-ray reading at 2355.5 meters indicates a much reduced clay mineral content. Although no clear correlation between cores and logs can be established at this depth, the change in the gamma-ray log agrees well with the change in clay mineralogy that defines the top of Sub-unit 1B if the good core/log correlation observed in Core 29 is extrapolated upward.

Entry into the hole from the drill pipe took place at 2425.5 meters $(112.5 \mathrm{~m})$. The digitally recorded well $\log$ data do not pick up until 125.0 meters and these have been marked in Figure 12.

The caliper curve may be less reliable than the readings indicate since the sonic log has recorded borehole velocities, as for example, over the intervals 2425.5 to 2336.0 meters, 2451.0 to 2456.0 meters, and 2460.0 to 2463.0 meters. The sonic curve does show, however, a trend toward more consistent values from 2490.0 meters $(177.0 \mathrm{~m})$ which may correspond to the change from onset of the foraminifer/nannofossil ooze to chalk first observed in hand specimen at about 200 meters. 
Unit 2 (2536.3 m-2573.0 m [223.3-260.0 m]) Figure 13

Correlation between logs and cores suggests that the base of Sub-unit 1B occurs at a log equivalent depth of 2540.0 meters $(227.0 \mathrm{~m})$ although there is no direct evidence from the logs to support the pick at this depth.

The strongest correlation between cores and logs found in the hole occurs at 2576.0 meters $(263.0 \mathrm{~m})$ which corresponds to the sharp contact between glauconitic mudstone and volcanic tuff observed in Core 29. Shipboard measurements of density across the contact show a change from $1.55 \mathrm{~g} / \mathrm{cm}^{3}$ to $1.9 \mathrm{~g} / \mathrm{cm}^{3}$ accompanied by sharp increase in sonic velocity from $1.37 \mathrm{~km} / \mathrm{s}$ to $1.5 \mathrm{~km} / \mathrm{s}$. This change places the base of Unit 2 at 2590.5 meters $(257.5 \mathrm{~m})$ where the sonic $\log$ values increase from $137 \mathrm{~km} / \mathrm{s}$ to 1.5 $\mathrm{km} / \mathrm{s}$ at the top of the glauconite mudstone section. In Core 29 , the fall in $\mathrm{CaCO}_{3}$ content to nearly zero confirms the major lithological break.

\section{Unit 3 (2573.0-2812.0 m [260.0-499.0 m]) Figure 13}

Sub-unit 3A (2573.0-2687.0 $\mathrm{m}$ [260.0-368.0 m]): The top of Sub-unit $3 \mathrm{~A}$ is confirmed on the logs at 2571.0 meters $(258.0 \mathrm{~m})$. The uppermost part of Core 29 consists of glauconitic mudstone (glauconite $20-40 \%$ ) with mica (3-5\%) and clay minerals (up to $10 \%$ ). Below 2576.0 meters $(263.0 \mathrm{~m})$, there is a progressive increase in tuffaceous material which continues to 2582.5 meters $(269.5 \mathrm{~m})$ where the gamma ray shows a sharp increase from around 30 API units to 60 API units. Between 2582.5 and 2657.0 meters $(344.0 \mathrm{~m})$, mudstones containing little glauconite are the predominant lithology (Cores 31-35). Breaks in the core record correlate well with inflection points observed on the gamma-ray curve.

Mica is an important constituent especially in the mudstone sections of Unit 3. In such cases, the use of a scintillometer scanner would help to confirm the $\log /$ core correlation in zones of poor core recovery and, by segregation, confirm if the mica present has a radioactive component which affects the GR reading.

Within Sub-unit 3A, it is suspected that the caliper curve is unreliable due to partial jamming of the caliper.

From 2657.0 meters $(344.0 \mathrm{~m}$ ) to 2678.0 meters $(365.0$ $\mathrm{m})$, tuffaceous material again becomes a prominent component. This is in good agreement with the suggested base of Sub-unit 3A where a rapid increase in tuffaceous material was established in Core 40 . The gamma-ray curve also shows a marked inflection at this point. The core descriptions suggest that peaks on the gamma-ray curve between 2646.0 and 2665.5 meters may reflect large concentrations of plant debris. In this case, scintillometer scanning and segregation could be used to test this assumption.

Sub-unit 3B (2681.0-2731.0 m [368.0-418.0 m]) Figure 14: Below the basal part of Sub-unit $3 \mathrm{~A}$ (Core 40), the proportion of tuffaceous material increases at the expense of mudstone so that Core 41 can be described as a muddy tuff. Below the middle of Core 42 , there is an increase in clay mineral content. Between 2699.0 and 2703.0 meters $(386.0-390.0 \mathrm{~m})$ the presence of a mudstone bed can be inferred by analogy with uphole log characteristics. From

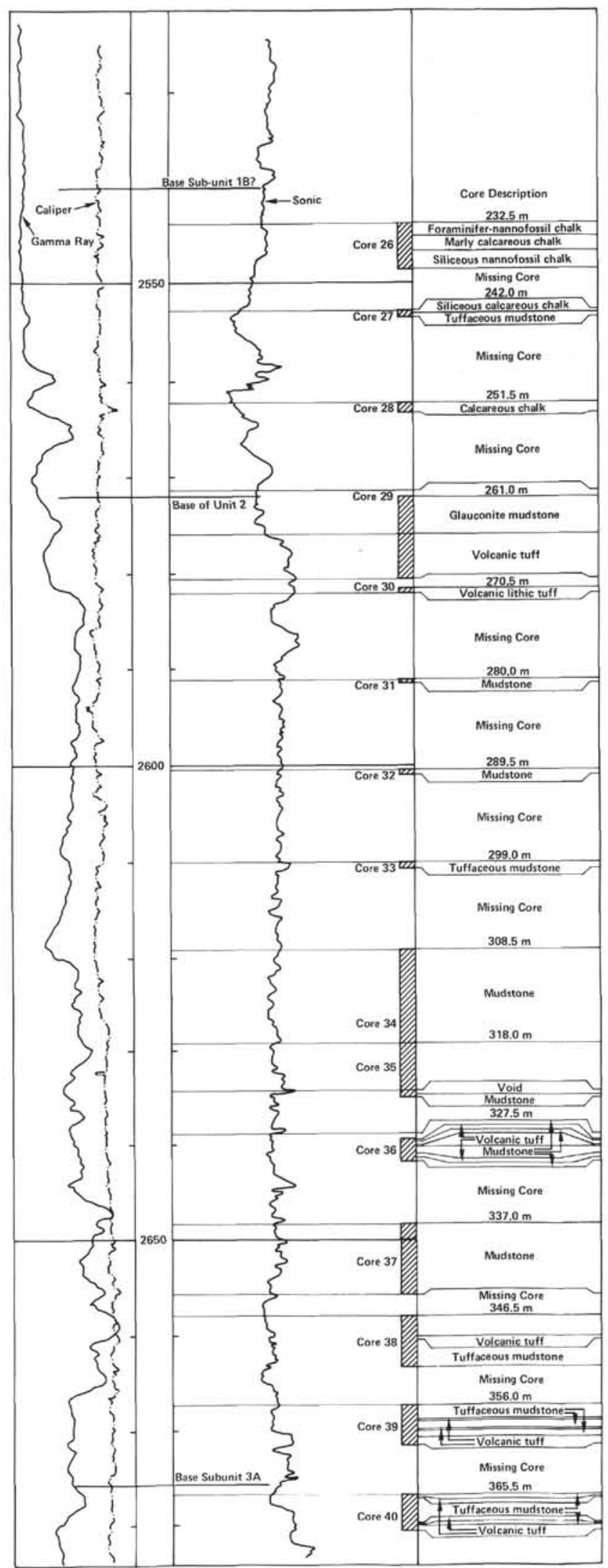

Figure 13. Core-log correlation: 232.5 to 365.5 meters; lithologic Units 2 and 3. 


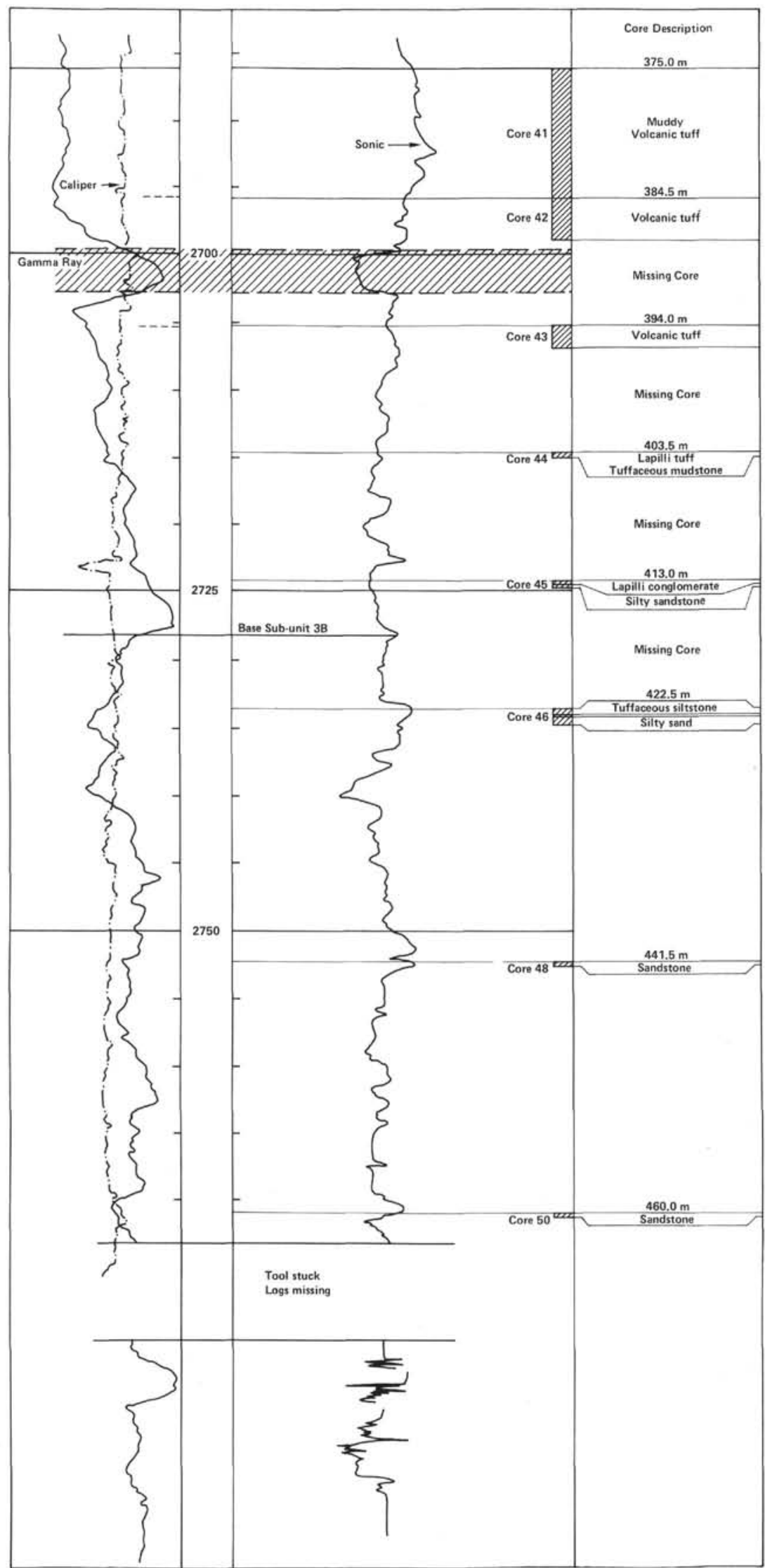

Figure 14. Core-log correlation: 375.0 to 460.0 meters; lithologic Unit 3. 
2703.0 meters $(390.0 \mathrm{~m})$ to the base of Sub-unit $3 \mathrm{~B}$, the gamma-ray curve shows a well-defined gradient that suggests increasing clay mineral content. Below 2727.5 meters, core recovery was poor and, although the amount of tuffaceous material has decreased radically, any conclusions concerning lithology are speculative.

\section{Crossplots}

Greater detail regarding the background and use of crossplots has already been given in the Site 401 Report together with references.

Only a limited number of combination plots were possible on this well because of the reduced logging suite (sonic GR, CAL).

\section{Sonic Versus Gamma-Ray " $Z$ " Plot - Caliper Size Superimposed}

Figure $15(2438.0-2547.0 \mathrm{~m}$ [125.0-234.0 m]) shows the fairly consistent GR readings in the range 10 to 20 API units. Above 2490.0 meters $(177.0 \mathrm{~m})$ the sonic readings exceed $165 \mu \mathrm{s}$. Below this depth to the base of Sub-unit 1B, there is less scatter and sonic readings show a much tighter grouping from $150 \mu \mathrm{s}$ to $165 \mu \mathrm{s}$. These two groups have been marked on the plot.

Figure $16(2547.0-2575.0 \mathrm{~m}$ [234.0-262.0 m]) readings are confined to Unit 2. The upper part of the section shows a continuation of the mainly chalk deposition seen at the base of Sub-unit 1B. The increasing marly content as shown by the GR peaks is clearly seen on the plot and most of the same readings remain in excess of $160 \mu \mathrm{s}$.

Figure 17 (2575.0-2679.0 m [262.0-366.0 m]) covers essentially Sub-unit $3 \mathrm{~A}$. Note the abrupt shift in plotted points to the southwest. The upper glauconitic mudstone has been marked by corridor lines and shows the GR readings in the range 30 to 40 API units. At 2582.0 meters $(269.5 \mathrm{~m})$ there is an abrupt shift in the GR reading from 30 to 40 to 60 API units which correlates with the mainly mudstone lithology seen in Cores 31 to 35 . Tuffaceous material again becomes prominent towards the base of the section.

Figure $18(2679.0-2699.0 \mathrm{~m}$ [366.0-386.0 m]) covers the upper section of Sub-unit 3B. The amount of tuffaceous material present markedly increases and is shown by a reduction in sonic reading to 120 to $140 \mu \mathrm{s}$.

In Figure $19(2700.0-2730.0 \mathrm{~m}[387.0-417.0 \mathrm{~m}])$ the mudstone bed of 2699.0 to 2703.0 meters (386.0-390.0 m) is well marked by the rise in GR reading to nearly $100 \mathrm{API}$ units and the accompanying increase in $\Delta_{t}$ to $160 \mu \mathrm{s}$. A distinct gradient on the GR marking an increase in clay mineral content is seen on the 1:200 logs. In view of the fairly steady sonic reading, there may well be a fining downwards sequence superimposed.

Figure $20(2438.0-2730.0 \mathrm{~m}[125.0-417.0 \mathrm{~m}])$ is a composite of Figures 15 to 19 inclusive with the main lithology patterns indicated.

\section{CONCLUSIONS}

1) The reduced logging suite has rendered core/log correlation more difficult. A density log would have been invaluable in reinforcing the interpretation.

2) Although the caliper is apparently reliable, there is good reason to believe that the device was partially jammed.
3) The core/log correlation through the hole is based mainly on the evidence from Core 29 where the change in sonic velocity and density at the junction between the glauconitic mudstone and volcanic tuff can be matched with the logs.

4) Log depths are approximately two to three meters shallower than core depths.

5) Gamma-ray peaks appear to reflect increases in clay content although it is probable that micas may also contribute to the total gamma-ray activity. However, this contribution may be small because a gamma-ray minimum is associated with a mica content of 20 per cent in Core 46 .

6) Routine scintillometer scanning of cores may aid core/log correlation and is recommended as standard procedure.

\section{CORRELATION OF SEISMIC PROFILES WITH DRILLING RESULTS}

Seismic reflection data in the vicinity of Sites 403 and 404 consisted principally of a detailed multichannel seismic survey made by Seismograph Services (England) Ltd., for the Institute of Oceanographic Sciences (UK) on behalf of the Department of Energy. The multichannel data were acquired using a 2160-cubic inch airgun array and 48-channel hydrophone with 50 meters between traces. The digitized data were resampled at $4 \mathrm{~ms}$ and subjected to true amplitude recovery prior to 24 -fold processing using deconvolution before and after stack and time varied filtering. Profiles across the sites have also been processed using diffraction stack migration and 24-fold equalizing stacking with instrument phase compensation.

Site 403 was located close to SP 14980 on profile IPOD-76-7 on the seismic profile occupied by Glomar Challenger during the site approach. Site 404 was located at SP 15460 on the adjacent profile IPOD-76-8 (Figures 5, 6, 21).

The multichannel seismic profiles across the sites show several reflectors of contrasting acoustic character discussed here in order of increasing depth.

Reflector 1 is overlain at Site 403 by about $0.3 \mathrm{~s}$ of acoustically transparent sediments characterized by a few laterally impersistent reflectors that are unconformable internally and with respect to reflector 1 . The sequence decreases laterally in thickness from $0.3 \mathrm{~s}$ at SP 15000 to $0.26 \mathrm{~s}$ beneath the channel at SP 15100 . Towards the base of this sequence, a stronger reflector $1 \mathrm{~A}$ pinches out against reflector 1 at SP 15010 on line IPOD-76-7 and at SP 15550 on line IPOD-76-8. The intra $1 \mathrm{~A}-1$ sequence thickens southeastward on profiles IPOD-76-7 and IPOD-76-8.

Reflector 2 lies at about $0.52 \mathrm{~s}$ depth at SP 14980 on profile IPOD-76-7 and is a strong, slightly irregular, westward dipping reflector. Within the intra 2-1 section, reflectors $2 \mathrm{~A}(0.40 \mathrm{~s})$ and $2 \mathrm{~B}(0.49 \mathrm{~s})$ onlap eastward against reflector 2. Reflector $2 \mathrm{~B}$ is thus cut out and the intra $2-1$ section reduced to $0.1 \mathrm{~s}$ thickness at Site 404 . The general westward thickening of the intra $2 \mathrm{~A}-1$ sequence and divergence of reflectors $2 \mathrm{~A}$ and $2 \mathrm{~B}$ suggest a westward progradation. The intersecting profiles (e.g., IPOD-76-5) show that reflectors $2 \mathrm{~A}$ and $2 \mathrm{~B}$ may form the top and bottoms of two southwesterly prograding units. 


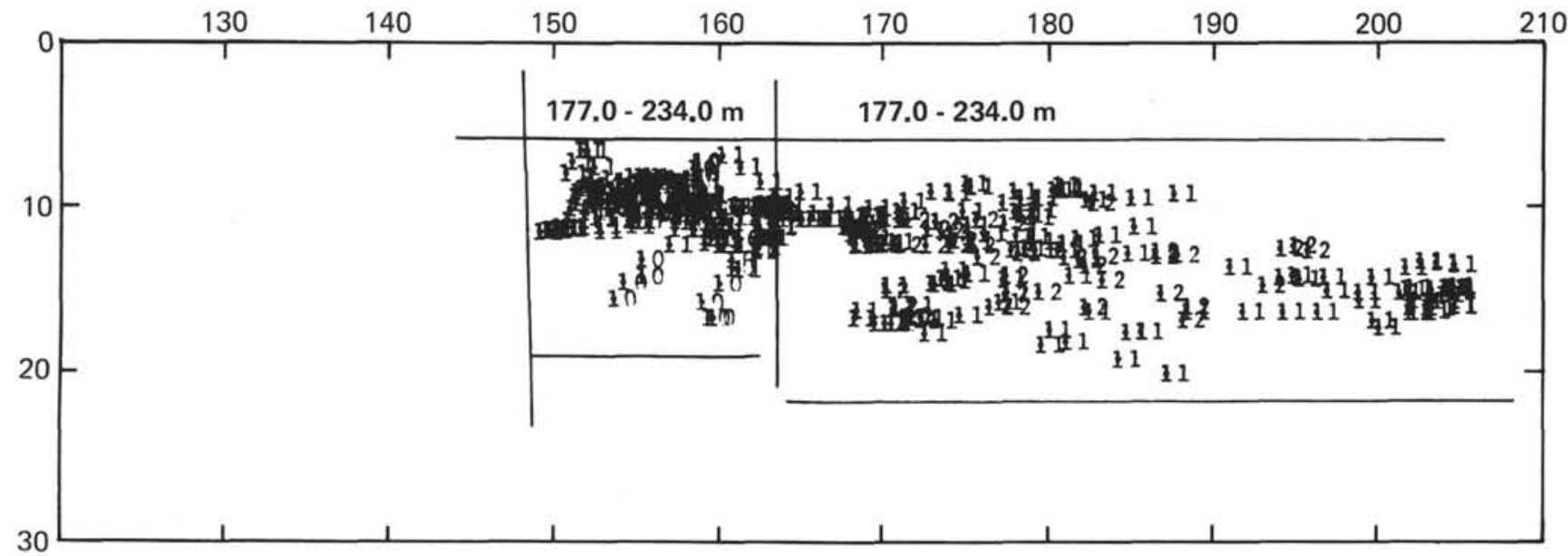

Figure 15. Sonic versus gamma-ray " $Z$ " plot (2438.0 to $2547.0 \mathrm{~m}, 125.0$ to $234.0 \mathrm{~m}$ ).

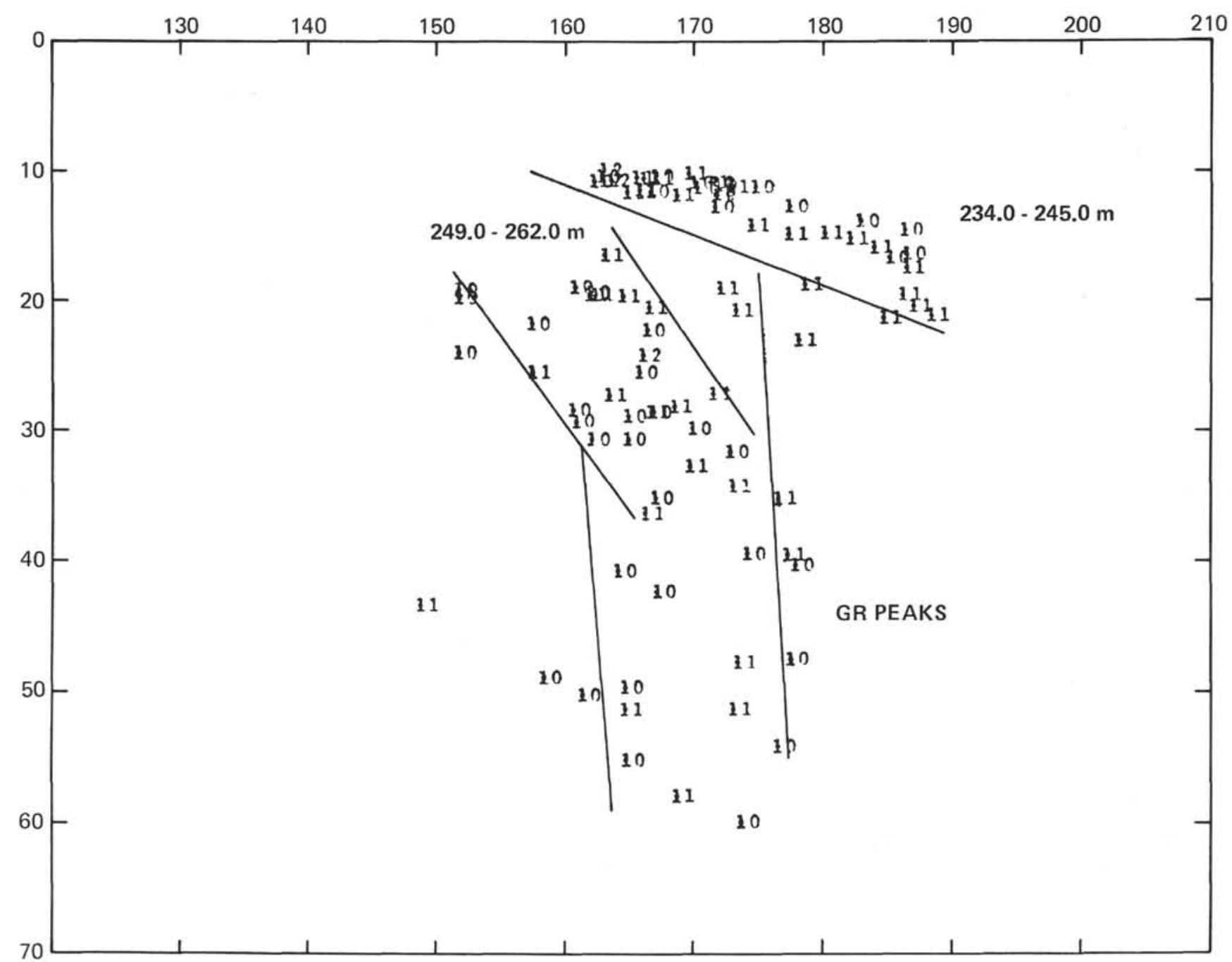

Figure 16. Sonic versus gamma-ray " $Z$ " plot (2547.0 to $2575.0 \mathrm{~m}, 234.0$ to $262.0 \mathrm{~m})$. 


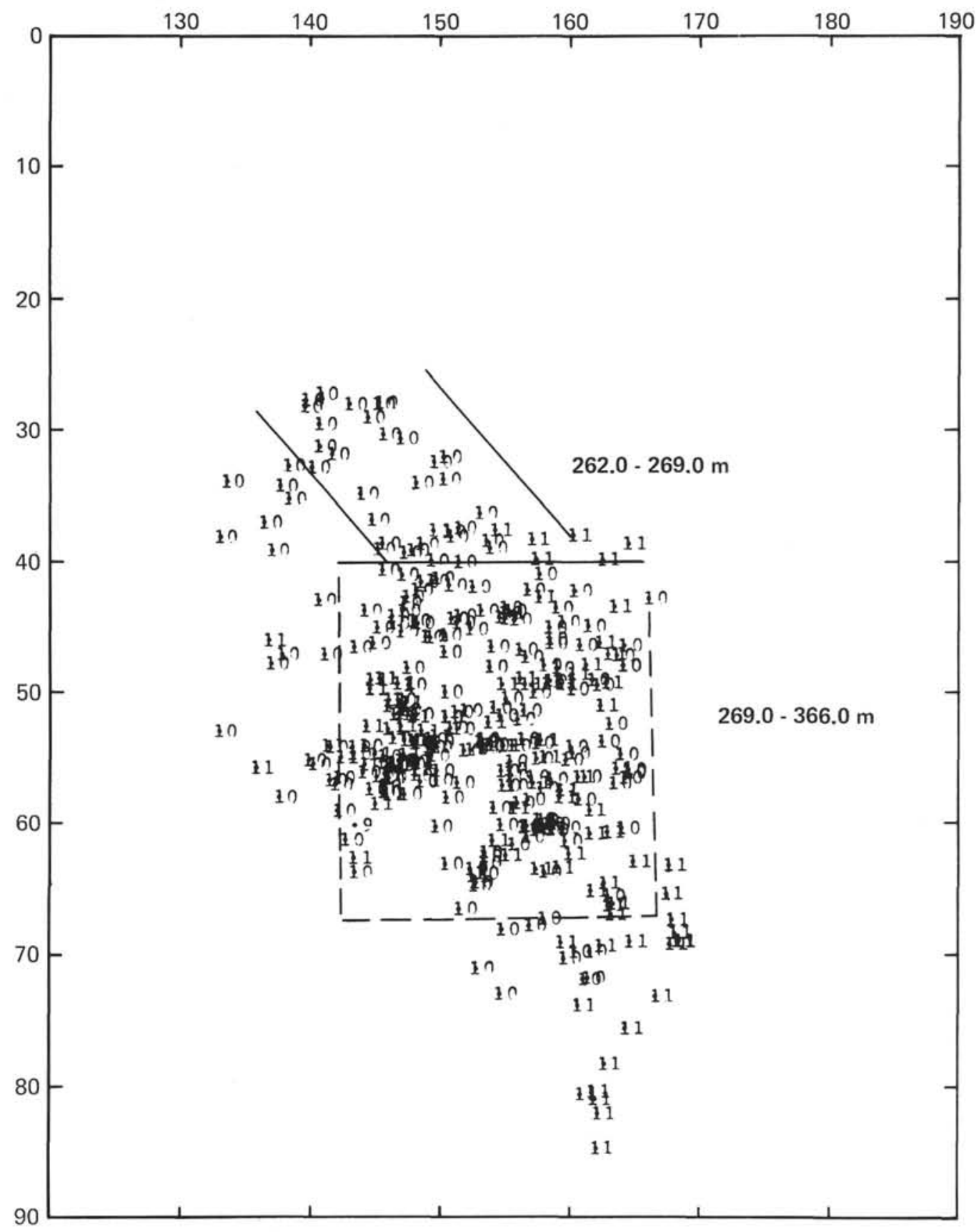

Figure 17. Sonic versus gamma-ray " Z" plot $(2575.0$ to $2679.0 \mathrm{~m}, 262.0$ to $366.0 \mathrm{~m})$. 


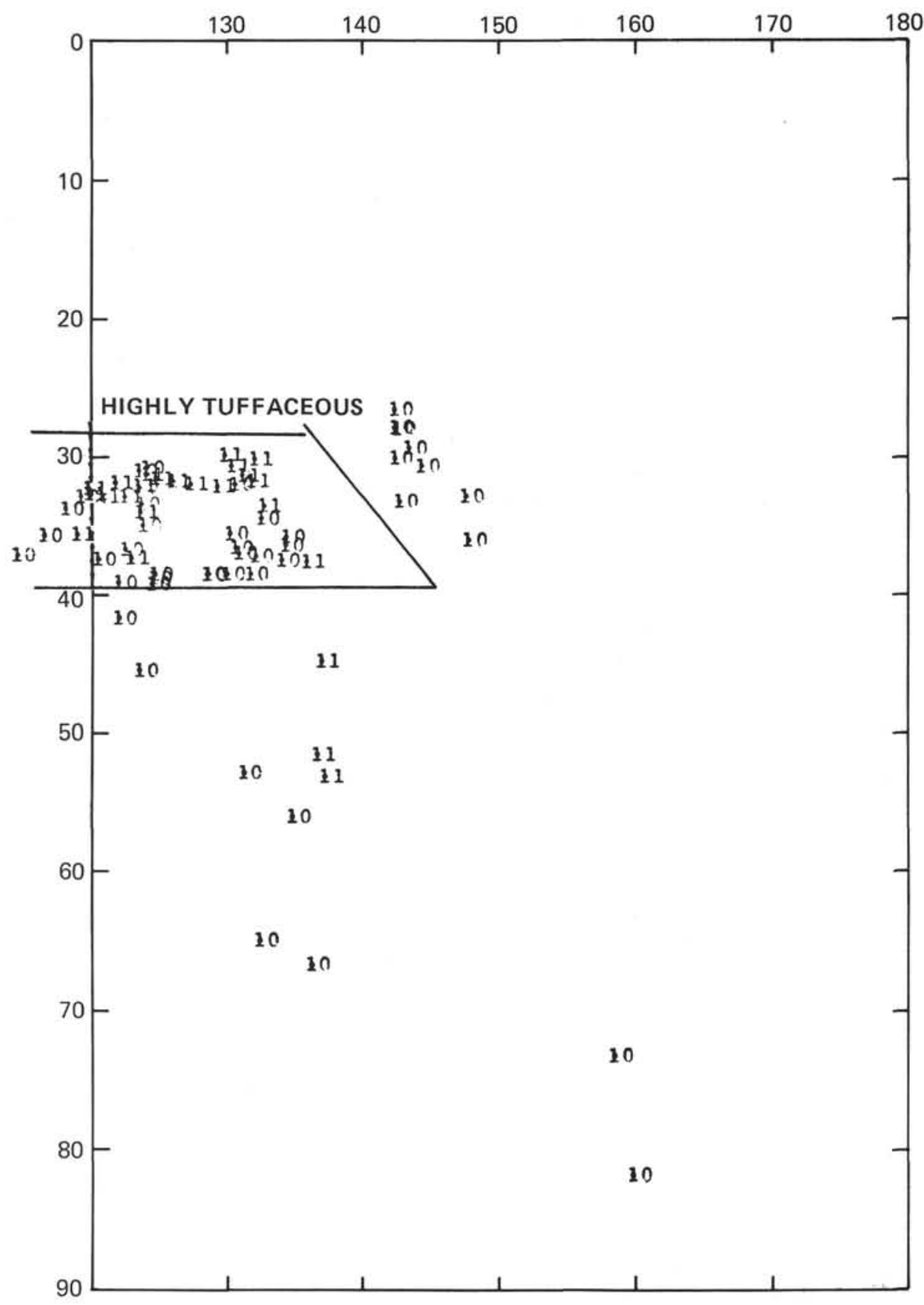

Figure 18. Sonic versus gamma-ray " $Z$ " plot (2679.0 to $2699.0 \mathrm{~m}, 366.0$ to $386.0 \mathrm{~m}$ ). 


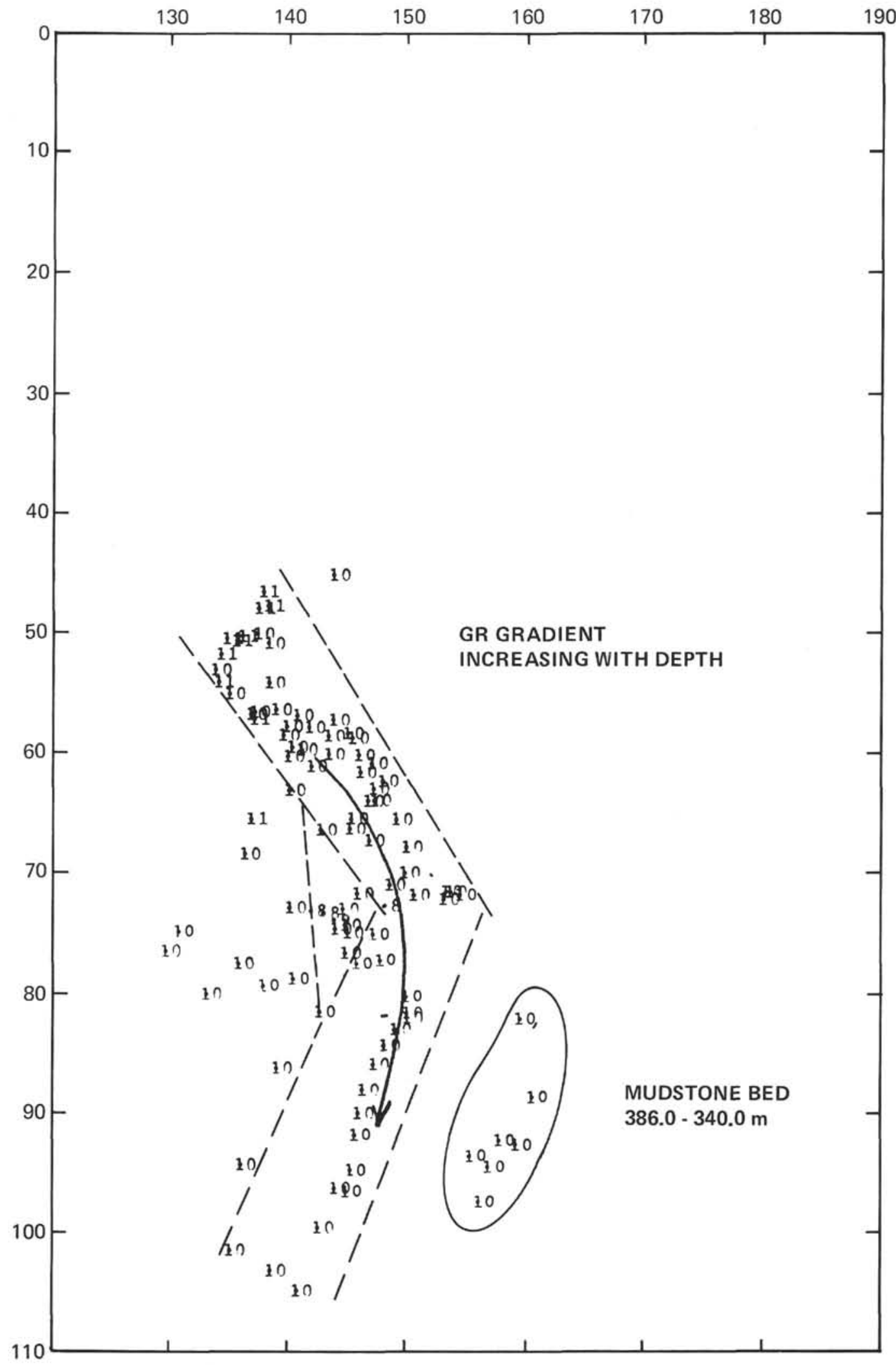

Figure 19. Sonic versus gamma-ray " $Z$ " plot (2700.0 to $2730.0 \mathrm{~m}, 387.0$ to $417.0 \mathrm{~m})$. 


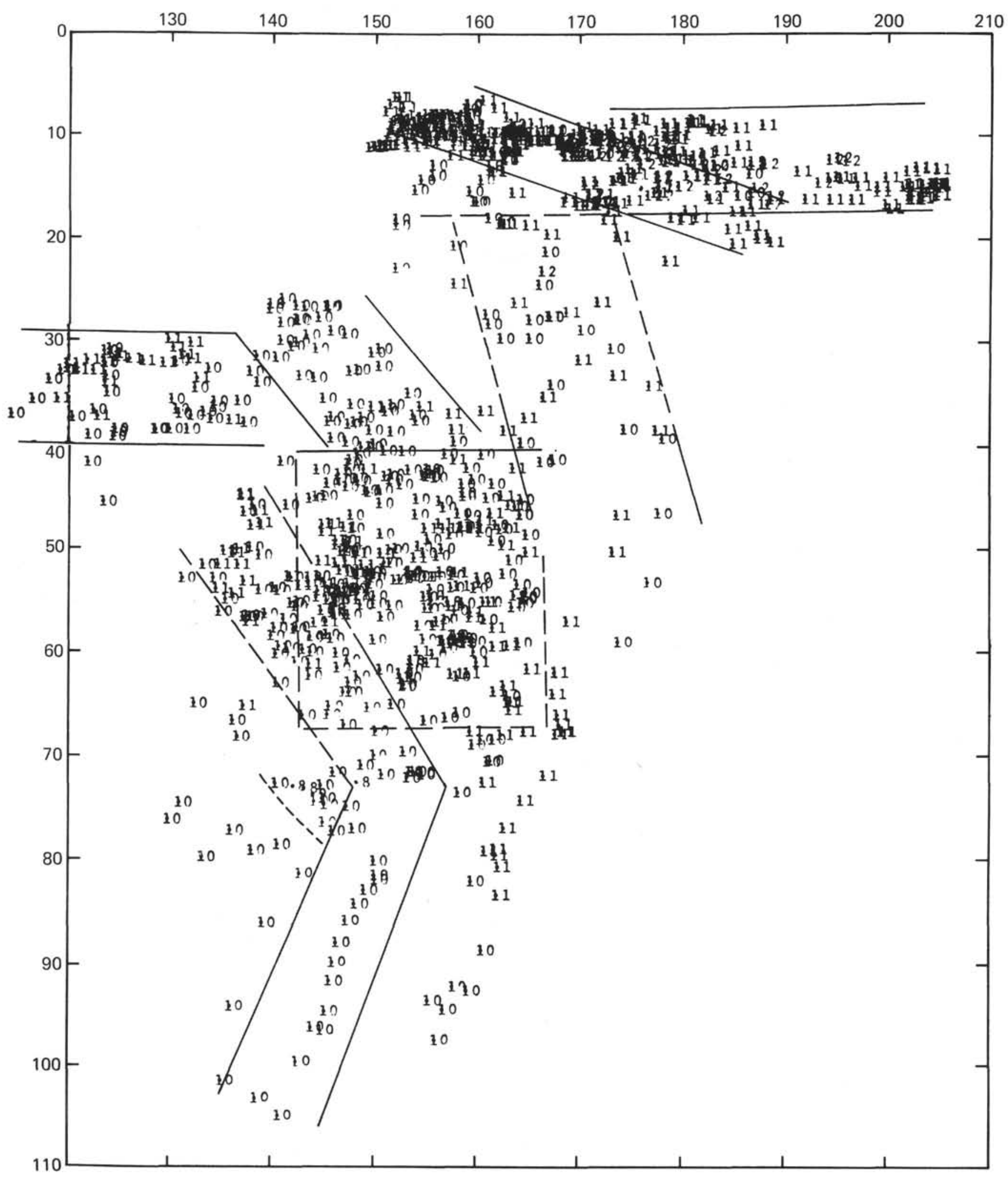

Figure 20. Sonic versus gamma-ray composite of Figures 15 to 19; principal lithologies also shown. 


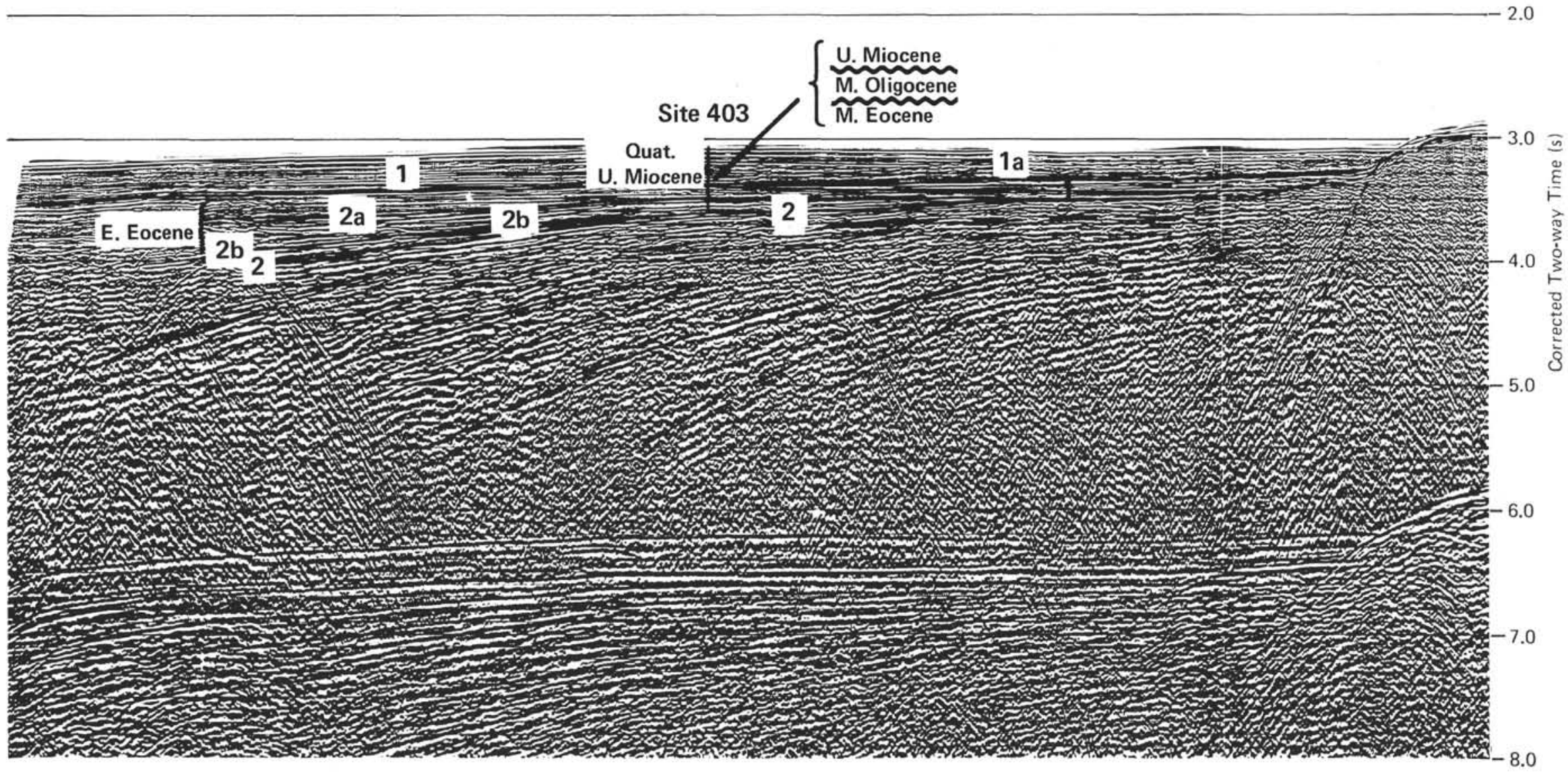

Figure 21. Multichannel seismic profile IPOD 76-8 through Sites 403 and 404. 
Beneath reflector 2 , at least $2.5 \mathrm{~s}$ of sedimentary section is present. Within the section, flat-lying reflectors dip more steeply to the northwest in a manner suggestive of westward deltaic progradation. The flat-lying reflectors at SP 15000 may, for example, represent the topset beds of a deltaic sequence. It should be noted that reflector 2 overlaps eastward over this section but, to the west, reflectors $2,2 \mathrm{~A}$, and $2 \mathrm{~B}$ appear as single events in a depositional continuum that extends up to reflector 1 and is broken only by the change in the character of the reflectors at the level of reflector 2 .

For Site 403, correlation between the seismic reflectors and stratigraphy has been made using synthetic seismograms generated from the single gamma-sonic log run downhole. The principles of generation of synthetic seismograms from acoustic and density logs have been described previously and will not be repeated here. As in the other holes logged during Leg 48 , it was necessary to suspend the drill stem about 100 meters below the sea bed to support the bumper subs so that the upper part of the hole was not logged. To provide the control to construct an accurate velocity model between the sea bed and the top of the sonic $\log$, a sonic velocity $\log$ was generated by interpolating between the shipboard measurements on the cores of sonic velocity. From this log and the downhole $\log$, synthetic seismograms (Figure 22) were generated assuming a mean density of $1.0 \mathrm{~g} / \mathrm{cm}^{3}$. The synthetic seismograms generated using zero-phase bandpass filters approximating 20 and $30 \mathrm{~Hz}$ Ricker wavelets and time-varied filtering included displays of primaries, only primaries without transmission loss, all order multiples only, primaries plus all order multiples.

The generalized lithology of Site 403 is shown with the gamma-sonic log in Figure 23. Between the sea bed and 230 meters, there are no major changes in sonic velocity or carbonate content in the lithologically uniform foraminifer/ nannofossil oozes and chalks. The unconformity between the upper Miocene and Oligocene strata is associated with a decrease in sonic velocity, but no change in carbonate content, and does not apparently give rise to a reflection. Between 240 and 260 meters, there are several sharp changes in sonic velocity and gamma, one of which marks the unconformity between the middle Eocene and the lower Eocene. However, the peak in acoustic impedance does not coincide with the unconformity but with a tuff, some 28 meters below. The synthetic seismogram shows that this bed lies at $0.30 \mathrm{~s}$ depth in close agreement with the observed depth of reflector 1 .

A second peak in sonic velocity and acoustic impedance at 365 meters in tuffaceous calcareous mudstones also coincides with an increase in drilling rate and decrease in gamma. The synthetic seismogram gives a travel time to this depth of $0.42 \mathrm{~s}$ in good agreement with the observed depth of reflector $2 \mathrm{~A}$ of $0.40 \mathrm{~s}$. At 465 meters, the sonic tool stuck in unconsolidated sands and quartzose tuffaceous mudstones which yield poor recovery. The integrated travel time to this depth is $0.48 \mathrm{~s}$ and suggests that reflector $2 \mathrm{~B}$ may arise from lithified beds at the base of the unconsolidated sands.

The correlations of the reflectors at Site 403 are summarized below and in Figure 23.

\begin{tabular}{|c|c|c|c|}
\hline & & ce & \\
\hline $0.41 \mathrm{~s}$ & $\begin{array}{l}\text { reflector } 1 \\
\text { reflector } 2 \mathrm{~A}\end{array}$ & lower Eoc & $\begin{array}{l}\text { tuffaceous calcareous } \\
\text { mudstone }\end{array}$ \\
\hline $0.49 \mathrm{~s}$ & reflector $2 B$ & lower Eocene? & $\begin{array}{l}\text { base unconsolidated } \\
\text { quartzose tuffaceous } \\
\text { sandstones? }\end{array}$ \\
\hline $.54 \mathrm{~s}$ & refle & not pen & \\
\hline
\end{tabular}

At Site 404 , the following reflectors are present:

\begin{tabular}{ll}
\hline reflector 1A & $0.23 \mathrm{~s}$ \\
reflector 1 & $0.33-0.34 \mathrm{~s}$ \\
reflector 2 & $0.41 \mathrm{~s}$ \\
\hline
\end{tabular}

Because no logs could be run downhole at Site 404, the correlation between the seismic reflectors and the cored section is based largely on the physical properties using the procedure outlined in this section of the Site 400 Report (this volume). In brief, variations in wet bulk density, sonic velocity, carbonate content and acoustic impedance were compared to lithologies and drilling rates. In addition, a multichannel velocity analysis at nearby SP 15479 provided interval velocities and depths as a further constraint.

\begin{tabular}{cccc}
\hline $\begin{array}{c}\text { Depth (sub-sea bed) } \\
\text { (ms two-way time) }\end{array}$ & $\begin{array}{c}\text { Interval } \\
\text { Velocity } \\
\text { (km/s) }\end{array}$ & $\begin{array}{c}\text { Thickness } \\
\text { (m) }\end{array}$ & $\begin{array}{c}\text { Depth } \\
\text { (sub-sea bed) } \\
(\mathrm{m})\end{array}$ \\
\hline 0-50 & 1.480 & 37 & 37 \\
$50-250$ (reflector 1A) & 1.639 & 164 & 201 \\
$250-330$ (reflector 1) & 1.490 & 60 & 261 \\
$350-450$ (reflector 2) & 1.990 & 119 & 380 \\
& & 380 & \\
\hline
\end{tabular}

The shipboard sonic velocity measurements gave a mean velocity of $1.7 \mathrm{~km} / \mathrm{s}$ to 180 meters sub-sea bottom. Below this depth, carbonate content decreases in parallel with a decrease in acoustic impedance from 3.17 to 2.51 . These changes occur at the unconformity between the upper Miocene nannofossil chalks and middle Eocene porcellanites. The unconformity at 195 meters is at a calculated two-way time of $0.23 \mathrm{~s}$ in good agreement with the observed depth of reflector $2 \mathrm{~A}$ and the multichannel velocity analysis. Below this depth, substantial variations in acoustic impedance from 7.78 to 2.60 are present between 247 and 295 meters depth. Tuffaceous and calcareous porcellanites between 237.0 and 256.0 meters may correspond to a strong reflection immediately above reflector 1 . The most marked change is, however, at about 290 meters where sonic velocity falls from 2.6 to $1.8 \mathrm{~km} / \mathrm{s}$ and acoustic impedance from 5.08 to 2.60 corresponding to the appearance of tuffaceous glauconitic mudstones of early Eocene age (cf. Site 403). This depth corresponds to a two-way time of $0.30 \mathrm{~s}$ at a velocity of $2.4 \mathrm{~km} / \mathrm{s}$ (averages between 190 and $290 \mathrm{~m}$ ) in good agreement with reflector 1 . Below this depth, the next major change in acoustic impedance from 3.16 to 4.80 is at 360.5 meters marking the change from mudstones to sandstones. The travel time to this depth using an average velocity of $2.1 \mathrm{~km} / \mathrm{s}$ is $0.4 \mathrm{~s}$ in good agreement with the observed depth of reflector 2 . 


$\begin{array}{ccccc}\text { ZERO PHASE BANDPASS } & \text { ZERO PHASE BANDPASS } & \text { A TIME VARIANT BANDPASS FILTER } \\ \text { FILTER APPROXIMATING A } & \text { FILTER APPROXIMATING A } & 12-15 & 50-55 \mathrm{~Hz} & \text { AT } 3.9 \mathrm{sec} \\ \text { 20 Hz RICKER WAVELET } & \text { 30 Hz RICKER WAVELET } & 7-10 & 40-44 \mathrm{~Hz} & \text { AT } 4.4 \mathrm{sec}\end{array}$
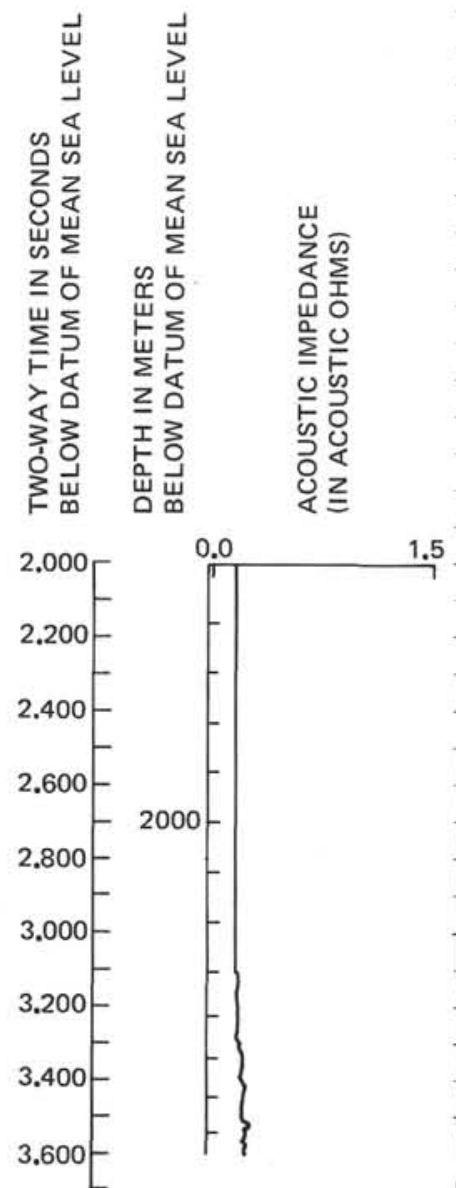
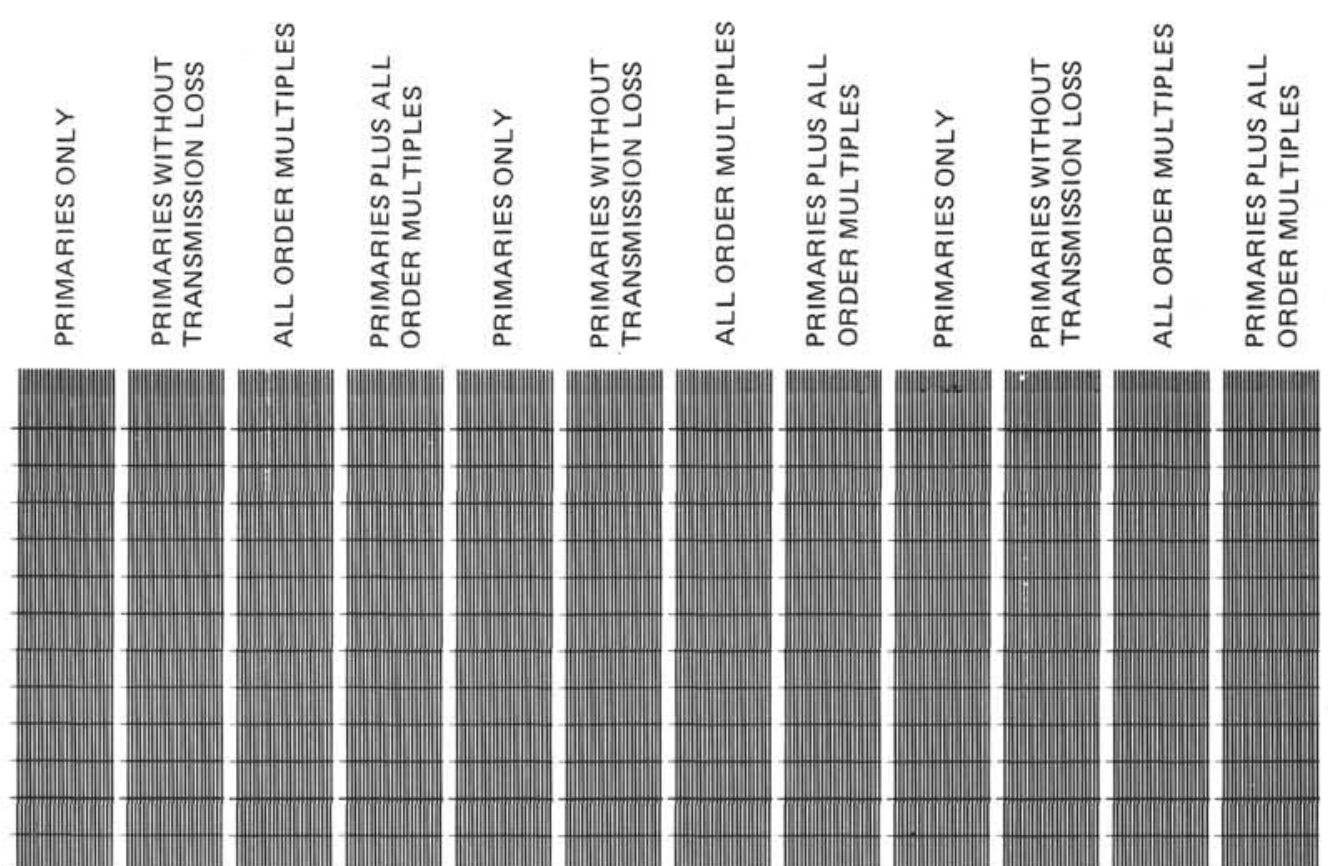


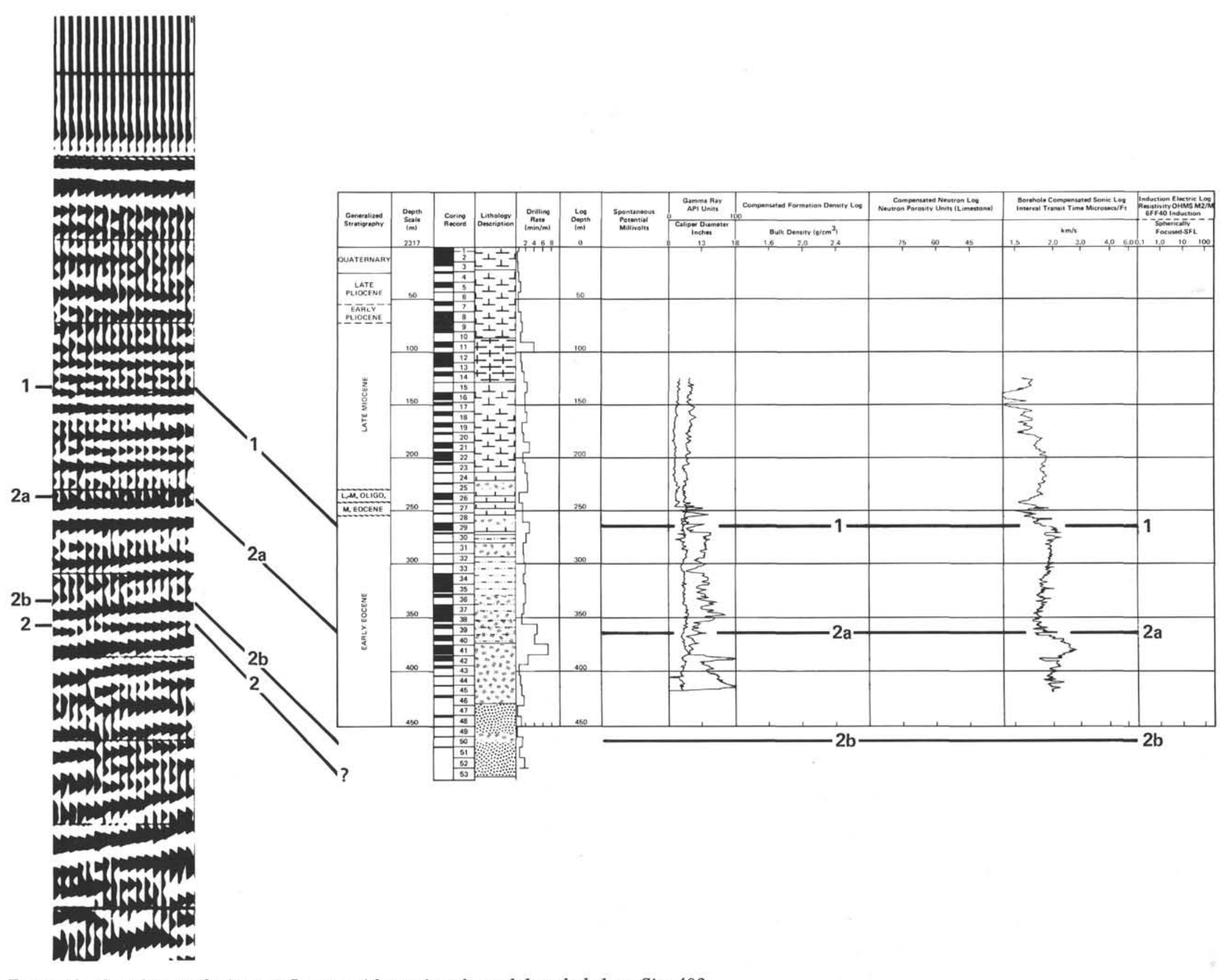


Conceivably, reflector 2 may arise from the conglomerate cut in the last core.

\section{SEDIMENTATION RATES}

\section{Site $\mathbf{4 0 3}$}

Based on nannofossil and foraminifer age determinations, the sedimentation rate for the Pliocene/Quaternary sequence at Site 403 is calculated to be $18 \mathrm{~m} / \mathrm{m}$.y., with no change during that time (Figure 24). A small hiatus, representing an interval of about $1.4 \mathrm{~m} . \mathrm{y}$., can be assumed for the lowermost Pliocene, based on nannofossils.
The thickness of the upper Miocene (NN 11 to N.16/ N.17) is 143.0 meters, representing a sedimentation rate of about $35 \mathrm{~m} / \mathrm{m}$.y. This rather large thickness of upper Miocene oozes may have accumulated by the winnowing effect of bottom currents flowing to the north along the west margin of Hatton Bank. The upper Miocene is underlain by middle to upper Oligocene sediments (NP 24/NP 25 to PN 21 to P.22), the hiatus marking an interval of about 15 m.y.; only 13.0 meters of middle-upper Oligocene sediment are present.

Another hiatus exists between the middle-upper Oligocene and the middle Eocene (NP 16 to P.11 to P.13)

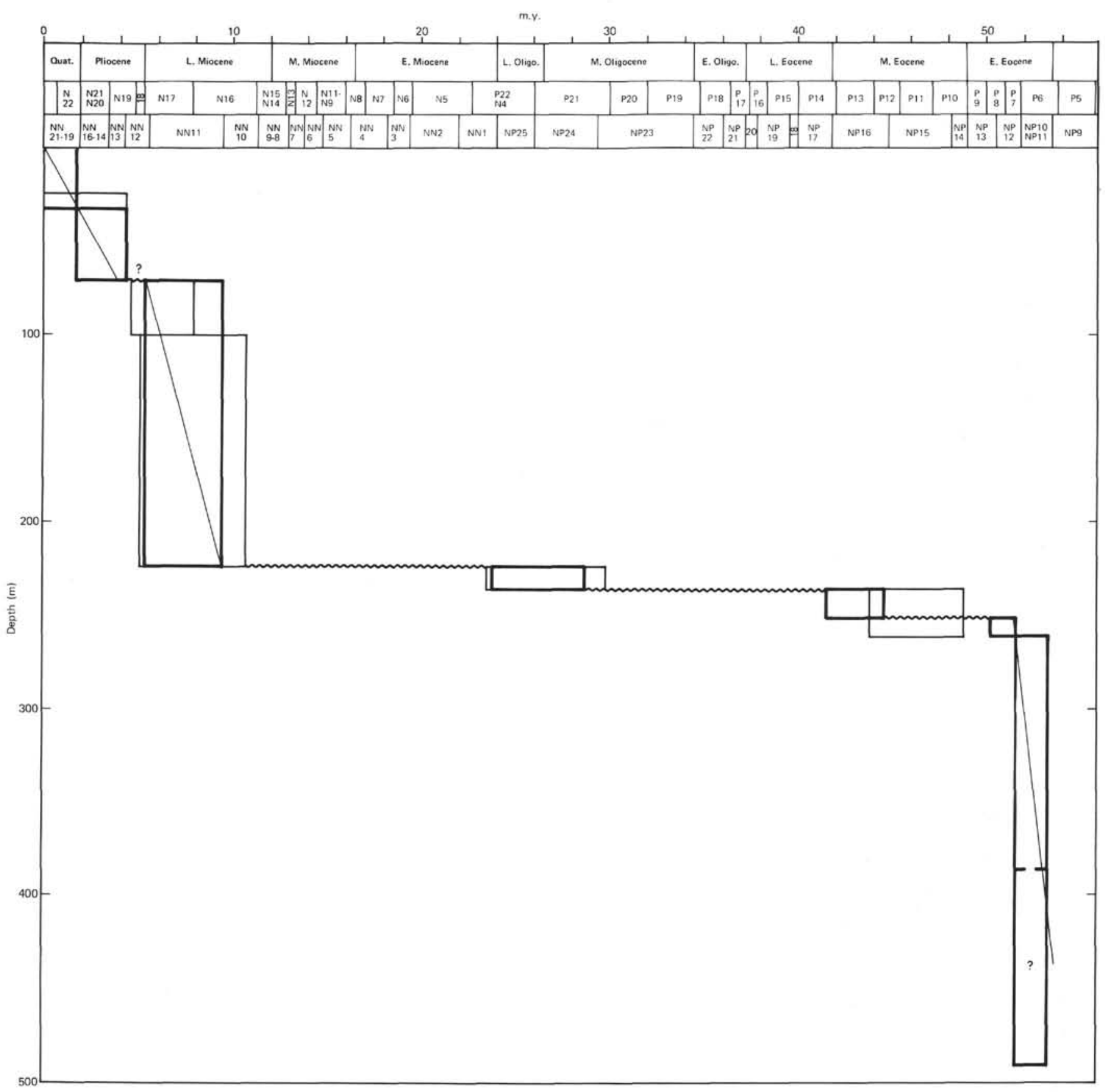

Figure 24. Sedimentation rate curve at Site 403. 
representing an interval of at least 13 m.y.; only 1.30 meters of middle Eocene sediments were recovered. The middle Eocene NP 16 zone is underlain by the lower Eocene NP 12 zone, the hiatus representing about $6.0 \mathrm{~m}$.y. The great number of hiatuses may reflect the high activity of bottom currents.

Lower Eocene sediments (lowermost NP 12 to NP 10) encompass at least from 251.5 to 381.5 meters (Cores 2841). Below, from 384.5 meters to the bottom of the hole at 490.0 meters, the sequence is barren of nannofossils. Assuming that the base of the Eocene lies in Sample 41, CC (what is not proven), the sedimentation rate for the lower Eocene sequence is at least $71.0 \mathrm{~m} / \mathrm{m} . \mathrm{y}$. However, according to Figure 24, the base of the Eocene is not reached in Core 41 , and the sedimentation rate, calculated from this figure, is as high as $87 \mathrm{~m} / \mathrm{m}$.y. Assuming the same sedimentation rate for the underlying sequence, the Paleocene/ Eocene boundary could be expected at about 402 meters, which corresponds with a lithological change from tuffaceous mudstone and lapilli tuff and conglomerates to sandstone. The high rate probably can be explained by the large input of volcanic material, either reworked or directly derived from subaerial volcanoes on the Reykjanes Ridge to the west.

\section{Site 404}

Sedimentation rates at Site 404 , which was drilled close to Site 403, are, as before, based on nannofossils and foraminifers (Figure 25). For the upper part of the sequence, which is spot cored, rates are imprecise. However, a rate of about $23 \mathrm{~m} / \mathrm{m} . \mathrm{y}$. can be assumed for the Pliocene/ Quaternary section which is slightly higher than the rate calculated for this stratigraphic interval at Site 403. A rate for the middle?/upper Miocene sequence was not calculated because of uncertain age determinations.

A hilatus, representing an interval of 38 to $40 \mathrm{~m} . \mathrm{y}$., lies between Core 6 and Core 7 , and a sedimentation rate of about $46 \mathrm{~m} / \mathrm{m} . \mathrm{y}$. is calculated for the 139 meters of lower Eocene sediments. Assuming the same sedimentation rate for the underlying sediments, the Paleocene/Eocene boundary could be expected at 360 meters, which corresponds well with the distinct change in lithology from mudstone to sandstone at this level and equates with the same lithological change at the Paleocene/Eocene boundary at Site 403 . The sandstones are probably of Paleocene age.

The lesser sedimentation rate for the lower Eocene sequence at Site 404 may be because of lesser volcanic material which was abundant at Site 403 .

\section{SUMMARY AND CONCLUSIONS}

Sites 403 and 404 were drilled on the southwest margin of the Rockall Plateau in 2317 to 2322 meters of water. Site 403 bottomed at 489 meters but was aborted due to torquing in unconsolidated sands. Site 404 was drilled nearby in an attempt to penetrate to the deeper horizons not reached in Site 403.

The rectilinear southwest margin of the Rockall Plateau is considered to have formed during spreading phases initiated at $76 \mathrm{~m} . \mathrm{y}$. and $56 \mathrm{~m} . \mathrm{y}$. The east-west segment of the margin was probably a fracture zone with an offset of about 100 miles, active between 76 and $56 \mathrm{~m} . \mathrm{y}$. The north- east-southwest segment of the margin apparently formed by rifting between Greenland and Rockall followed by spreading at $52 \mathrm{~m} . \mathrm{y}$. The basement of this margin is structured into a series of sediment-filled basins (Roberts et al., this volume) that strike parallel to the oldest magnetic anomalies recorded in the adjacent ocean crust. Sites 403 and 404 were located in one such basin approximately 30 $\mathrm{km}$ east of the oldest magnetic anomaly $(-24)$, and were selected from an IOS multichannel seismic survey of the basin.

Seismic profiles across the basin show a prominent unconformity at about $0.54 \mathrm{~s}$ depth. Below this unconformity, a series of strong, locally faulted reflectors dip oceanward in a manner suggestive of contemporaneous deposition and subsidence. The section below the unconformity is closely comparable to sections observed beneath the Outer Vøring Plateau and in the Lofoten Basin which have caused considerable controversy as to their age, nature, and relationship to the end of rifting and onset of spreading. Overlying this unconformity is a well-bedded sequence that exhibits progradation and thickens oceanward. The top of this interval is defined by a strong reflector at about $0.32 \mathrm{~s}$ depth that was considered to mark the onset of a more vigorous bottom circulation (Roberts, 1975).

The major objective of these sites was to examine the structural and stratigraphic evolution of a margin differing from the Bay of Biscay in age and the absence of tilted and rotated fault blocks.

Site 403 was cored continuously to TD but the upper part of the section at Site 404 was cored intermittently to 170 meters.

\section{Lithology}

The section penetrated at Sites 403 and 404 can be divided into three stratigraphic units ranging in age from Quaternary to late Paleocene. At Site 403, prominent hiatuses were found between the Oligocene and the upper Miocene and between the Oligocene and the lower Eocene. However, at Site 404 the Oligocene is absent and the upper Miocene rests directly on the middle Eocene.

\section{Unit 1}

Sub-unit 1A of Sites 403 and 404 consists of nannofossil ooze, marly foraminifer/nannofossil ooze, and calcareous mud. The clay mineral assemblage is dominated by smectite and quartz, though kaolinite and chlorite are present in persistent small amounts (10-20\%). Pebbles of various lithologies are present throughout the unit and may represent ice-rafted detritus. Benthic foraminifers indicate deposition in lower bathyal conditions with evidence of incursions of cold lower bathyal water (Murray, this volume). The sedimentation rate for the Pliocene and Quaternary was $18 \mathrm{~m} / \mathrm{m}$.y. (Figure 24 and Figure 25).

Sub-unit 1B consists of nannofossil ooze and foraminifer/nannofossil chalk. Megascopic observations suggest that the change from ooze to chalk occurs at 200 meters although the logs suggest a shallower depth of 176 meters. The sub-unit is characterized by its general uniformity and high carbonate content with the most significant variations occurring in the foraminifer- 


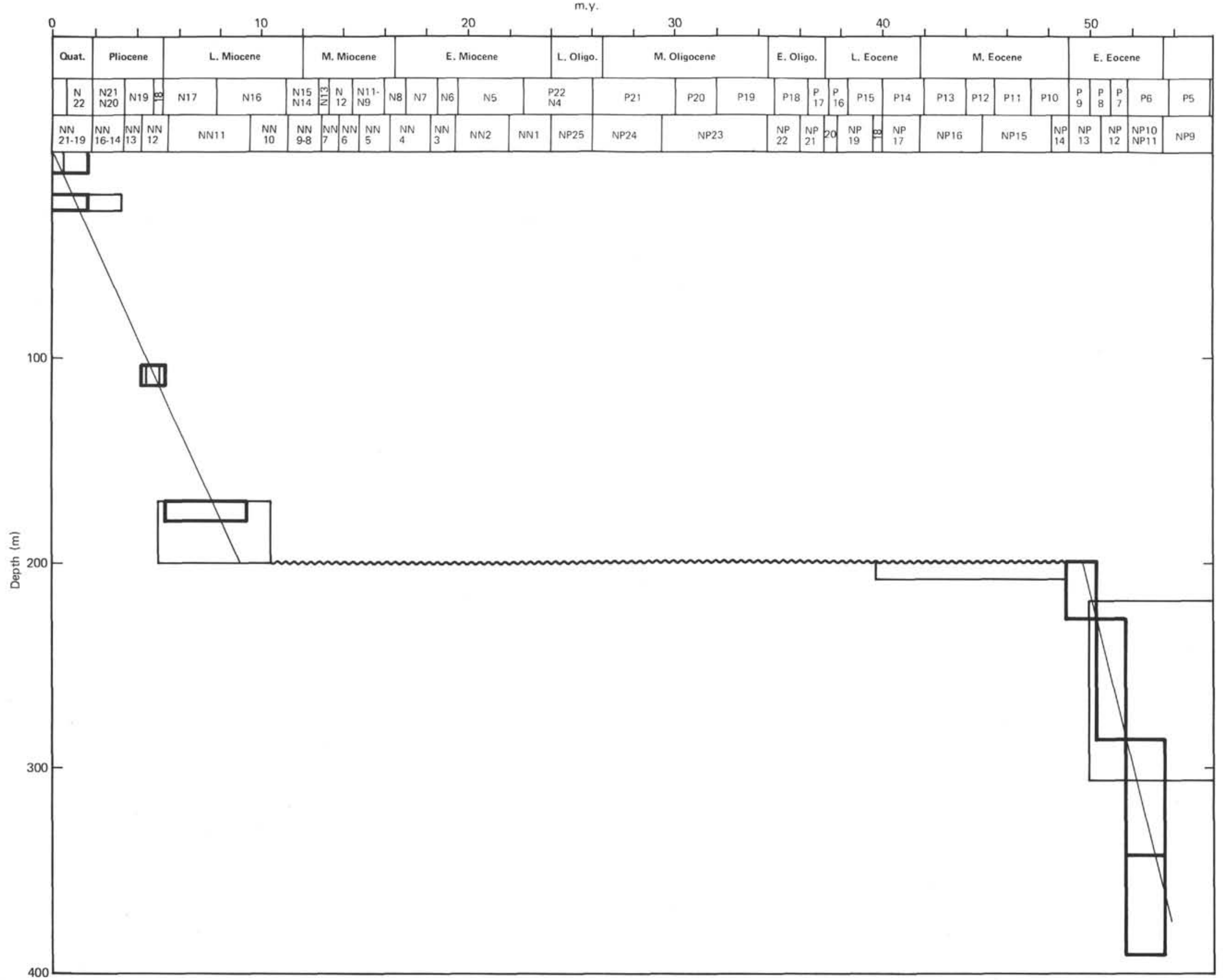

Figure 25. Sedimentation rate curve at Site 404. 
nannofossil ratio. Quartz and feldspar are absent, and kaolinite and chlorite are much reduced. The upper Miocene sediments were deposited in water depths between 2200 and 2400 meters at about $35 \mathrm{~m} / \mathrm{m}$.y. A small hiatus of about 1.4 m.y. may be present in the lower Pliocene.

\section{Unit 2}

At Site 403, the boundary between Unit 1 and Unit 2 corresponds to the $15-\mathrm{m} . \mathrm{y}$. hiatus between the upper Miocene and the middle/upper Oligocene: a second hiatus of at least $13 \mathrm{~m} . \mathrm{y}$. between the Oligocene and middle Eocene is also present within Unit 2. A third hiatus representing an interval of about $6.0 \mathrm{~m} . \mathrm{y}$. is present between the middle Eocene and lower Eocene. At Site 404, the Oligocene is absent and a hiatus of 38 to $40 \mathrm{~m}$.y. lies between the upper Miocene and the middle Eocene. The sediments at the base of Unit 2 in Sites 403 and 404 are early Eocene in age. It should be noted that Unit 2 is 37 meters thick at Site 403 compared to 95 meters at Site 404 .

At Site 403, greenish gray foraminifer/nannofossil chalk and yellowish gray to pale orange siliceous/calcareous chalk are the dominant lithologies of Unit 2 , in contrast to the olive-green to dusky-green porcellanites, spicule-bearing mudstones, siliceous tuffs, and glauconitic mudstones that predominate at Site 404. In the lower part of Unit 2 at Sites 403 and 404, glauconitic mudstones become more abundant, reflecting the transition to lithologies characteristic of Unit 3. Close to the base of the unit, there is a major change in mineralogy marked by the disappearance of the characteristic quartz, feldspar, and poorly crystallized smectite assemblage of Unit 3 and the appearance of illite, kaolinite, and chlorite. The distinctive heavy mineral assemblage comprising olivine and augite that characterizes much of Unit 2, is replaced by an assemblage comprised of diopside, tourmaline, hypersthene, apatite, zircon, and tourmaline (Harrison et al., this volume).

Plane cross-laminae and coarse biogenous remains of well-sorted sand grade are common and, in places, concentrated into thin calcarenite layers. Within Unit 2 of Site 404, eight tuffaceous interbeds are present and the glass shards of Core 14 have an R.I. of 1.57 indicating a basaltic affinity.

Studies of the benthic foraminifers (Murray, this volume) show a distinct change at the base of Unit 2 from mid-inner shelf depths below to an outer shelf environment at the base. The benthic foraminiferal paleoecology indicates a progressive deepening throughout deposition of Unit 2 until depths were about 600 meters by late Oligocene time. At Site 404, the middle Eocene fauna at the top of Unit 2 indicates outer-shelf depths in the probable range of 100 to 180 meters. It should be noted that the base of Unit 2 at Sites 403 and 404 is paleontologically correlative.

\section{Unit 3}

Most of Unit 3 consists of interbedded volcaniclastics and mudstones, distribution of which constitutes the main criteria for definition of the sub-units. There are significant differences in the lithology of Unit 3 at Sites 403 and 404 and the sites are therefore summarized separately. At both sites, however, the uppermost part of Unit 3 marks a significant change in the depositional environment shown both by heavy mineral assemblages and paleoecology.
Sub-unit 3A of Site 403 in its uppermost part consists of greenish black mudstone transitional with the basal part of overlying Unit 2 . The prominent tuff of air-fall origin found in Core 29 is considered to cause reflector 1. Through the sub-unit, there is an apparent steady decrease in size downward of the mudstones accompanied by a change in the character of the sedimentary structures. In the upper part, laminae, cross-laminae, and examples of foreset laminae are common, but below, where tuffaceous material is more abundant, the laminae are disrupted. Graded layers of tuffaceous material are also common. Benthic foraminifer studies indicate a changing paleoenvironment during deposition of Sub-unit 3A. For example, species that are dominant in deltaic marine environments of normal salinity of less than 10 meters depth occur in Core 34 in association with species indicative of brackish to marine waters, and may indicate deposition in a shallow inner shelf environment adjacent to a river. However, the assemblage Core 29 indicates deepening to mid or inner-shelf depths $(<100 \mathrm{~m})$ (Murray, this volume).

Sub-unit $3 \mathrm{~B}$ is distinguished by a predominance of tuffaceous material compared to Sub-unit $3 \mathrm{~A}$ above. The change is clearly marked by an abrupt increase in sonic velocity (that correlates with reflector $2 \mathrm{~A}$ ) and a change from tuffaceous mudstone to muddy tuff (Core 40). In the upper part of the sub-unit, angular vitric and lithic sands and granules comprising the tuff are associated with detrital plant fragments and fragmented megafaunal remains. Sedimentary structures are not conspicuous although there is evidence of graded bedding and contorted lamination comparable to the lower part of Sub-unit 3A. The limited core recovered from the lower part of the sub-unit and log data suggest an interbedded section of lapilli tuff (lapilli conglomerate), muddy tuff, and/or tuffaceous mudstone. Considerable reworking is indicated by intermixing of tuffaceous material with subrounded to well-rounded granules of quartz, microcline, and shell fragments. Conspicuous oligoclase-andesine and andesine-labradorite particles (pyroclasts?) may indicate andesitic volcanism (Harrison et al., this volume). The organic matter present in Core 42 has a high thermal index of 4 indicating temperatures around $350^{\circ} \mathrm{C}$ that may indicate a local heat source (volcanic?). The palynological assemblages are poor but indicate minor and only occasional marine invasions (Costa and Downie, this volume).

Sub-unit 3C of Site 403 (with poor core recovery) is characterized by decreasing tuffaceous material and the presence of alternating (?) unconsolidated muddy sand and fairly well-sorted calcite cemented sandstone. Other lithologies present include well-laminated tuffaceous siltstone, lignitic mudstone, and medium to very coarse unconsolidated sand. Arkosic sandstone is present in the basal section. The synthetic seismograms suggest that reflector $2 \mathrm{~B}$ may be associated with these lithologies.

At Site 404, Unit 3 consists of glauconitic mudstone with interspersed sandstones, marly limestones, and volcaniclastics. In contrast to Site 403 , only two sub-units were identified at Site 404 . Correlation of the seismic reflectors between the sites suggest that Sub-units $3 \mathrm{~A}$ and $3 B$ of Site 403 are equivalent to Sub-units $3 A$ and 3B of Site 403 and that Sub-unit $3 \mathrm{C}$ of Site 404 is cut out against the underlying reflector 2 . 
As in Site 403 , the uppermost part of Sub-unit $3 \mathrm{~A}$ consists of glauconitic mudstone and siliceous mudstones that include silty sand, sandy silt, silty clay, and are transitional with the base of Unit 2. The glauconitic mudstone passes down into a tuffaceous glauconitic mudstone that may be the cause of seismic reflector 1 . The tuff of Section 18-2 is petrographically similar to the tuffs found in Cores 30 and 35 of Site 403 and contains volcanic glass having an R.I. of 1.550 .

Fine-grained glauconitic mudstone interbedded with marly limestones and containing conspicuous tuffaceous material is present through the depth interval 313 to 332 meters. In the lower part of the sub-unit, mudstones predominate with occasional interbeds and nodules of marly limestone. The mudstones consist chiefly of firm sand and coarse silt, and show evidence of plane and cross-laminae as well as bioturbation. Sandy beds are present toward the base indicating a transition to Sub-unit 3B.

Studies of the benthic and planktonic foraminiferal assemblages of Cores 23 to 16 indicate that the lower part of Sub-unit $3 \mathrm{~A}$ (Cores 23 and 21) was deposited in shallow marginal marine environments which were probably brackish in the case of Core 21. The assemblages of Cores 18 and 17 are of inner-shelf type with a depth of 75 meters in contrast to the overlying Cores 16 to 9 which have assemblages indicative of middle to outer-shelf depths. A marked increase in the number and diversity of dinocysts at the top of Core 17 indicates a rapid change to a more offshore environment (Murray; Costa and Downie, both this volume).

Sub-unit 3B consists of sandstone with interbedded conglomerate and minor (?) glauconitic mudstone. Granule-sized lithic fragments in Core 25 included quartzite sandstone, schist, basalt, and hornfels. The tuffaceous conglomerate of Core 26, which contains lapilli and shell fragments including an oyster shell fragment, may cause the prominent reflector 2. Nannoplankton and foraminifers were rare or absent in Sub-unit 3B, but the palynology data indicate marine conditions that were very near shore in view of the dominance of terrestrial debris and pollen.

\section{Depositional History}

The oldest sediment observed on the seismic profiles through Sites 403 and 404 comprise a westward prograding sedimentary wedge, the upper surface of which is defined by reflector 2 . Attitudes of reflectors within the wedge indicate strong syn-depositional subsidence and faulting with local development of deltaic deposition. The underlying basement, the surface of which is rarely seen, is presumed to be continental on the evidence of gravity models (Scrutton, 1972) and nearby seismic refraction profiles (Gaskell et al., 1958). The sediments below reflector 2 were not penetrated in Sites 403 and 404, and their age and lithology must remain speculative. However, downward extrapolation of the rapid Paleocene sedimentation rates (Figure 24) suggests that the base may be as old as Middle Cretaceous or as young as earliest Tertiary. The high interval velocities and strong reflections within the interval may indicate an interbedded sequence of volcanics and clastics (Roberts et al., this volume). The conglomerate considered to represent reflector 2 indicates that the uppermost part of the sequence was deposited in near-shore to littoral conditions. However, the westerly dip of reflector 2 and the paleobathymetric reconstruction (Figure 26) indicate that 100 to 200 meters of submarine relief may have been present. The reconstruction also shows a substantial subaerial relief of at least 1500 meters at the fault (?) scarp defining the eastern edge of the basin. The sediments comprising the pre-reflector 2 sequence may have been eroded from these highlands to be deposited contemporaneously with faulting within the basin and along its margin. It should be noted that these sediments, and indeed the sequence above reflector 2 , were deposited prior to the spreading between Greenland and Rockall Plateau and are thus syn-rift deposits.

At Site 404, the littoral polymict conglomerate considered to cause reflector 2 is succeeded by minor sandstones and more polymict conglomerates. Beds equivalent to reflector 2 were not penetrated at Site 403, but sandstones and lignitic mudstones considered to lie just above it are succeeded by lapilli conglomerates (Figure 27). A precise correlation between these beds of Sub-units $3 \mathrm{~B}$ and 3 C of Site 403, and Sub-unit 3B of Site 404 has not been established, as foraminifers and nannoplankton are rare or absent. However, the palynological zonation shows that Core 23 of Site 404 (top of Sub-unit 3B) is equivalent to Core 41 of Site 403 (close to the top of Sub-unit 3B). To facilitate discussion of facies relationships below, reflector 2 is here assumed to be isochronous. Sub-unit 3B $(88.5 \mathrm{~m})$ of Site 404 is therefore equivalent to Sub-units $3 B$ and $3 C$ of Site 403 (total $121 \mathrm{~m}$ ).

At Site 404 , the conglomerate causing reflector 2 is considered to represent the uppermost facies of the "deltaic" wedge identified on the seismic profiles. Polymict pebbles indicate the proximity of exposed continental basement and contemporaneous volcanism. The overlying sediments were deposited in marine but very near-shore conditions. In contrast, the laterally equivalent sandstones and lignitic mudstones of Site 403 are considered to have been deposited in relatively deeper water conditions. Palynological evidence of occasional marine incursions during deposition of Sub-unit $3 \mathrm{~B}$ suggests that the sands may be transgressive deposits formed during reworking of the "delta." At Site 403, tuffaceous mudstones are dominant in Cores 41 to 44 , but were subject to considerable reworking. Nearby andesitic volcanism is also indicated by the high thermal indexes and petrographic evidence. The tuffaceous facies passes laterally into sandstones between Sites 403 and 404 and the disappearance of underlying reflector $2 \mathrm{~B}$ may also be due to this facies' change. The disappearance of tuffaceous material over the short distance between the two sites is puzzling in view of its presumed air-fall origin. The disappearance may be more apparent than real in view of the poor recovery at Site 404 , though it may also reflect the dispersal of the ash fall under prevailing wind and current conditions.

During deposition of Sub-unit 3A, the geography of the basin changed as the axis of deposition migrated to form a broad, possibly leveed ridge built by southwestward progradation, resulting in different depositional conditions at Sites 403 and 404 . At Site 404 the basalt mudstones (Cores 21 to 23) of Sub-unit 3A were deposited in shallow water marginal marine conditions that became brackish. At 


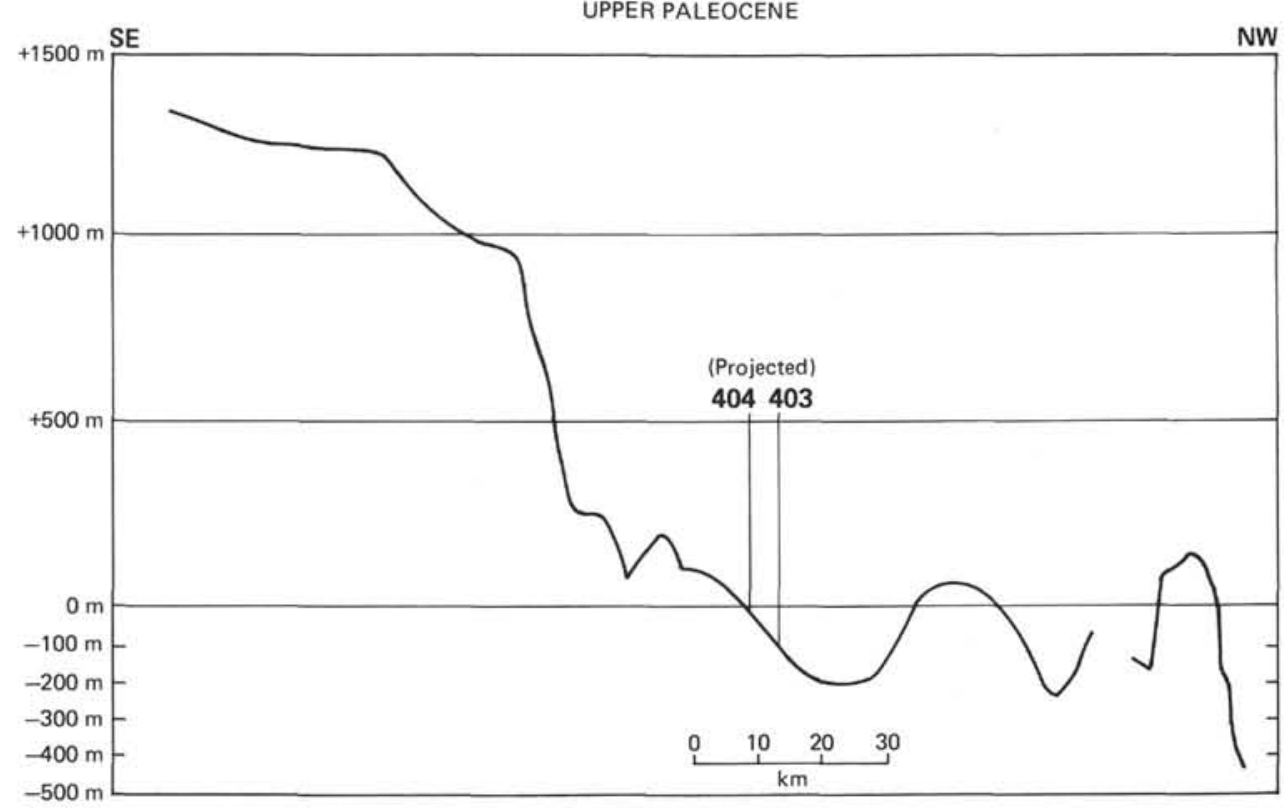

Figure 26. Paleocene paleobathymetry Sites 403 and 404.

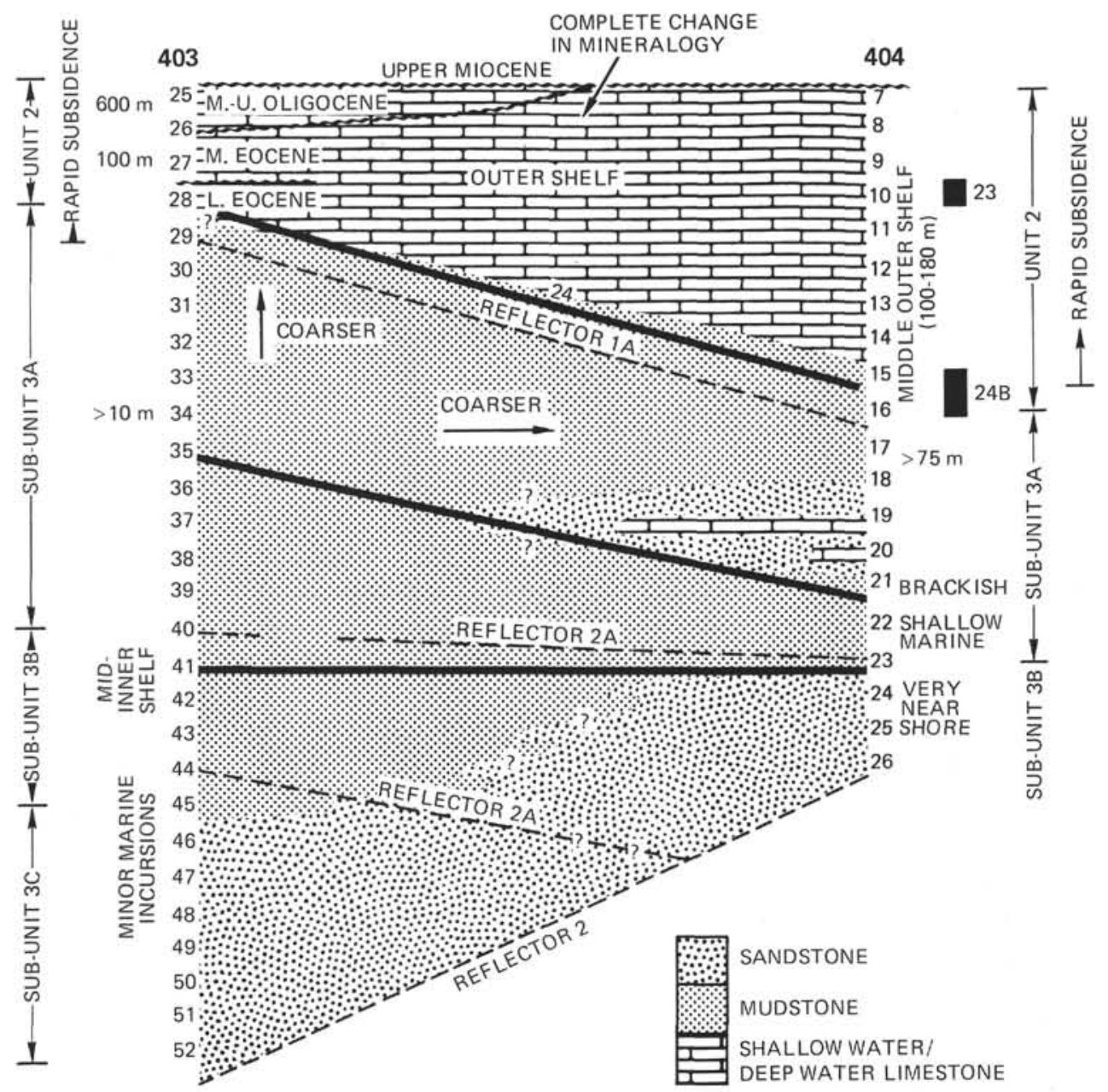

Figure 27. Stratigraphic and lithologic correlation Sites 403 and 404. 
Site 403, however, deposition exceeded subsidence, resulting in depths that may have been as shallow as 10 meters by NP 10 time. The faster sedimentation at Site 404 may be due to a greater volcaniclastic input although increasing detrital input is also indicated by the upward coarsening of the sequence. In post-NP 10 time, sedimentation was still more rapid at Site 403 although the site had subsided to mid inner-shelf depths by NP 12 time. At Site 403 , the site subsided to depths of $>75$ meters in the same interval. This transgressive phase may have caused deposition of sands and marly limestones at Site 404 . Contemporaneous volcanism is evidenced by the significant tuffaceous component at both sites and by the prominent tuff considered to cause reflector 1 .

The most dramatic change in the geography of the basin took place in NP 12 time resulting in the marked lithological break between Sub-unit $3 \mathrm{~A}$ and Unit 2. Paleomagnetic studies (Hailwood, this volume) show that the break corresponds in time to anomaly-24, and thus to the initiation of spreading between Greenland and Rockall Plateau. At both sites, a marked increase in the rate of subsidence is recorded by the rapid change from depths of less than 75 meters to depths of 100 to 180 meters. Submergence of the adjacent land may be recorded by the disappearance of the heavy mineral assemblage associated with erosion of a nearby granulitic terrain and the appearance of illite, chlorite, and kaolinite. However, dominant augite and olivine in the heavy mineral assemblage suggests erosion of a basaltic terrain. Decrease in land-derived detritus is also shown by the dominance of siliceous chalks and porcellanites. Abundant biogenic silica and glauconite in these sediments may also indicate that upwelling on the slope or outer shelf first developed at this time. Faster sedimentation at Site 404 may reflect infilling of the flanking depression of the levee. Tuff bands in Unit 2 indicate contemporaneous subaerial volcanism perhaps on the Iceland-Faeroe Rise.

During middle Eocene and Oligocene times, deposition was spasmodic at both sites at different times. At Site 403, a hiatus is present between Zones NP 12 and NP 16, but at Site 404 deposition was continuous to Zone NP 13 with only a minor hiatus. Zones NP 14 and NP 15 are therefore absent at both sites. The section absent at Site 403 is represented at Site 404 by calcareous and tuffaceous porcellanites deposited in middle to outer-shelf depths. However, by NP 16 time, tuffaceous mudstones were deposited in epibathyal conditions at Site 403. During the hiatus between the middle Eocene and the Oligocene, subsidence continued as the Oligocene beds were deposited in 600 meter depths. The major hiatus lies between the upper Miocene and Oligocene at Site 403 and between the upper Miocene and the middle Eocene at Site 404. Drilling at DSDP Sites 116 and 117 (Leg 12) on Rockall Plateau also encountered the Oligocene/Miocene hiatus.

Although an origin for these hiatuses must be sought in non-deposition and/or erosion, such processes are themselves a reflection of changing ocean circulation. Oxygen isotope studies (Létolle et al., this volume) show that progressive cooling at oceanic surface and bottom water took place in both Biscay and Rockall during Eocene time leading to the establishment of the psychrosphere by 38 m.y. The cooling is matched by a decrease in ${ }^{13} \mathrm{C}$ that may reflect an increase in productivity due to influxes of nutrients by the cold water masses. One consequence of this cooling would have been the development of a more intense bottom circulation driven by stronger density gradients and resulting in non-deposition and/or erosion. The increased production of biogenic silica may reflect high nutrient concentrations in upwelling water. The circulation change began in NP 12 time and may have been most intense between NP 13 and NP 16 time. A further intensification in circulation is evidenced by the Oligocene/Miocene hiatus, but cooling of surface and bottom waters cannot be invoked because temperatures increased toward the Miocene. The intensified circulation may be related, however, to increased exchange of bottom water between the Norwegian and Iceland Basins due to subsidence of the Iceland-Faeroe Rise below sea level in Oligocene/Miocene time (Thiede, in press).

By late Miocene time, both sites had subsided to their present depth. Although the seismic reflection profiles show that the post-upper Miocene section has accumulated under the influence of ocean bottom currents, the geologic data suggest that the bottom currents and temperatures have varied through this time (Roberts, 1975; Roberts et al., this volume). The upper Miocene is characterized by warmer bottom waters and increased sedumentation compared to the Pliocene-Pleistocene section, although laminae and/or coarse layers suggest variations in bottom velocities. Cooling of the bottom water in Pliocene time, as demonstrated by paleotemperature and faunal evidence, was undoubtedly caused by glaciation of the Northern Hemisphere (Létolle et al., this volume) revealed by abundant ice-rafted debris throughout the Pliocene and Pleistocene at both sites. Within the Pliocene/Pleistocene section, carbonate-mudstone cycles may reflect glacial and interglacial periods and the Pliocene hiatus may also reflect intensified bottom water circulation.

The sedimentary record at Sites 403 and 404 on the western margin of the Rockall Plateau micro-continent documents the evolution of a passive rifted margin from rifting to the present. During the rifting stage, tilted and rotated fault blocks did not develop; contemporaneous littoral sediments accumulated in a rapidly subsiding basin bounded by high mountains. Following the accretion of ocean crust at anomaly-24 time (52 m.y.), the basin subsided rapidly to reach its present depth by late Miocene time. Prominent hiatuses within the middle Eocene and Neogene section reflect changes in the intensity of ocean bottom water circulation due to cooling of ocean surface and bottom water, and greater exchange of water between the Norwegian Sea and Iceland Basin due to subsidence of the Iceland-Faeroe Rise.

\section{REFERENCES}

Berggren, W. A., 1970. Cenozoic biostratigraphy and paleobiogeography of the North Atlantic. In Laughton, A. S., Berggren, W. A., et al., Initial Reports of the Deep Sea Drilling Project, v. 12: Washington (U.S. Government Printing Office), p. 965-1001.

Bott, M. H. P., Browitt, C. W. A., and Stacey, A. P., 1971. The deep structure of the Iceland-Faeroe Ridge, Mar. Geophys. Res., v. 1, p. 328-351. 
Bott, M. H. P., Sunderland, J., Smith, P. J., Casten, U., and Saxon, 'S., 1974. Evidence for continental crust beneath the Faeroe Islands, Nature, London, v. 248, p. 202-204.

Bullard, E. C., Everett, J. E., and Smith, A. G., 1965. The fit of the continent around the Atlantic, Phil. Trans. Roy. Soc., London, v. 258, p. 41-51.

Casten, U., 1973. The crust beneath the Faeroe Islands, Nature, London, v. 241, p. 83-84.

Curray, J., et al., 1976. Passive ocean margins, Geotimes, v. 21, p. 26-27.

Dobson, M. R., Garrett, P., Haynes, J. R., Jenkins, D. G., and Medani, A. H., 1976. Upper Cretaceous and Cenozoic carbonates from the margins of the Rockall Trough, North Atlantic, J. Geol. Soc., London, v. 132, p. 611-622.

Ewing, J. and Ewing, M., 1958. Seismic refraction measurements in the Atlantic Ocean basins, in the Mediterranean Sea, on the Mid-Atlantic Ridge and in the Norwegian Sea, Geol. Soc. Am. Bull., v. 70, p. 291-318.

Gaskell, T. F., Hill, M. N., and Swallow, J. C., 1958. Seismic measurements made by H.M.S. Challenger in the Atlantic, Pacific and Indian Oceans and in the Mediterranean Sea, 1950-53, Phil. Trans. Roy. Soc., London, v. 251, p. 23-83.

Godby, E. A., Hood, P. J., and Bower, M. E., 1968. Aeromagnetic profiles across the Reykjanes Ridge south of Iceland, J. Geophys. Res., v. 73, p. 7637-7649.

Jones, M. T. and Roberts, D. G., in preparation. Marine magnetic anomalies in the eastern North Atlantic Ocean.

Laughton, A. S., 1971. South Labrador Sea and the evolution of the North Atlantic, Nature, London, v. 232, p. 612-617.

Laughton, A. S., Berggren, W. A., et al., 1971. Initial Reports of the Deep Sea Drilling Project, v. 12: Washington (U.S. Government Printing Office).

Le Pichon, X., Hyndman, R., and Pautot, G., 1972. Geophysical study of the opening of the Labrador Sea, J. Geophys. Res., v. 76, p. $4712-4743$.

Miller, J. A., Roberts, D. G., and Matthews, D. H., 1973. Rocks of the Grenville age from Rockall Bank, Nature Phys. Sci., v. 246 , p. 61 .

Moorbath, S. and Welke, H., 1969. Isotopic evidence for the continental affinity of Rockall Bank, North Atlantic, Earth Planet Sci. Lett., v. 5, p. 211-216.

Olivet, J. L., Le Pichon, X., Monti, S., and Sichler, B., 1974. Charlie-Gibbs fracture zone, J. Geophys. Res., v. 79, p. 2059-2072.

Roberts, D. G., 1970. Recent geophysical investigations on the Rockall Plateau and adjacent areas, Geol Soc. London Proc., v. 1662 , p. $87-93$.
1971. New geophysical evidence on the origins of the Rockall Plateau and Trough, Deep-Sea Res., v. 19, p. 353-359.

, 1975. Marine Geology of the Rockall Plateau and Trough, Phil. Trans. Roy. Soc. London, v. 278, p. 447-509.

Roberts, D. G., Ardus, D. A., and Dearnley, R., 1973a. Pre-Cambrian rocks drilled from the Rockall Bank, Nature Phys. Sci., v. 244, p. 21-23.

Roberts, D. G., Flemming, N. C., Harrison, R. K., and Binns, P., 1973b. Helen's Reef: A Cretaceous microgabbroic intrusion in the Rockall intrusive center, Mar. Geol., v. 16, p. M21-M30.

Roberts, D. G., Matthews, D. H., and Eden, R. A., 1972. Metamorphic rocks from the southern end of Rockall Bank, $J$. Geol Soc. London, v. 128, p. 501-506.

Ruddiman, W. B., 1972. Sediment distribution on the Reykjanes Ridge: seismic evidence, Geol. Soc. Am. Bull., v. 83, p. 2039-2062

Scrutton, R. A., 1970. Results of a seismic refraction experiment on Rockall Bank, Nature, London, v. 227, p. 826-827. 1972. The structure of Rockall Plateau microcontinent, Geophys. J., v. 27, p. 259-279.

Scrutton, R. A. and Roberts, D. G., 1971. Structure of the Rockall Plateau and Trough. Northeast Atlantic. In ICSU/SCOR WG31 Symposium, Cambridge, 1970; the geology of the East Atlantic Continental Margin, Europe, Rept. 70/14, Inst. Geol. Sci., v. 12, p. 77-78.

Soper, N. J., Higgins, A. C., Downie, C., Matthews, D. W., and Brown, P.E., 1976. Late Cretaceous-early Tertiary stratigraphy of the Kangerdlugssuak area, East Greenland and the age of opening of the Northeast Atlantic, J. Geol. Soc., v. 132, p. 85-104.

Thiede, J., in press. Tertiary palaeoceanography and the subsidence of the Iceland-Faeroes Rise, Phil. Trans. Roy. Soc. London.

Vogt, P. R, and Avery, O. E., 1974. Detailed magnetic surveys in the Northeast Atlantic and Labrador Sea, J. Geophys. Res., v. 79, p. 363-389.

Vogt, P.R., Avery, O.E., Schneider, E.D., Anderson, C.N., and Bracey, D.R., 1969. Discontinuities in sea floor spreading, Tectonophysics, v. 8 , p. 285 .

Vogt, P. R., Johnson, G. L., Holcombe, T. L., Gilg, J. G., and Avery, O. E., 1971. Episodes of sea floor spreading recorded by the North Atlantic basement, Tectonophysics, v. 12, p. 211-234.

Watts, A. B., Schreiber, B. D., and Habib, D., 1975. Dredged rocks from the Hatton Bank, Rockall Plateau, J. Geol. Soc. London, v. 131, p. 639-646. 